Columbia Law School

Scholarship Archive

The Rise of Independent Directors in the United States, 1950-2005: Of Shareholder Value and Stock Market Prices

Jeffrey N. Gordon

Follow this and additional works at: https://scholarship.law.columbia.edu/faculty_scholarship

Part of the Business Organizations Law Commons, and the Securities Law Commons 


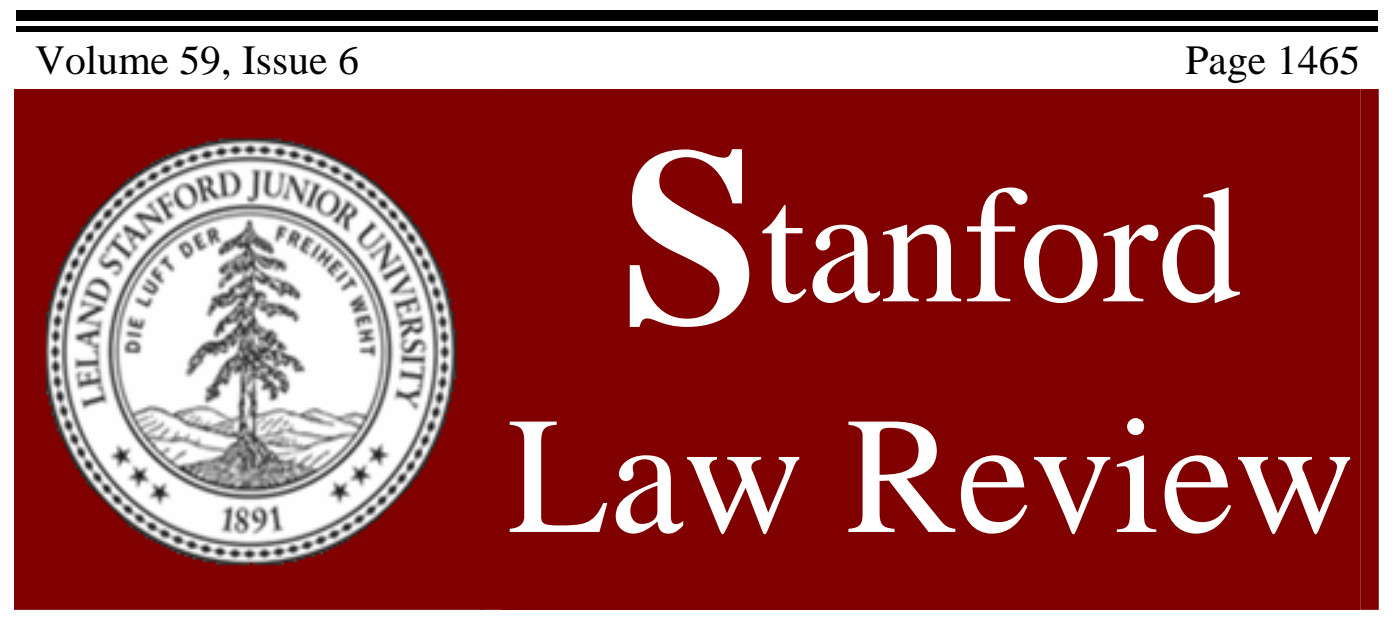

\section{THE RISE OF INDEPENDENT DIRECTORS IN THE UNITED STATES, 1950-2005: OF SHAREHOLDER VALUE AND STOCK MARKET PRICES}

Jeffrey N. Gordon

(C) 2007 by the Board of Trustees of the Leland Stanford Junior University, from the Stanford Law Review at 59 STAN. L. REV. 1465 (2007). For information visit http://lawreview.stanford.edu. 


\title{
ARTICLES
}

\section{THE RISE OF INDEPENDENT DIRECTORS IN THE UNITED STATES, 1950-2005: OF SHAREHOLDER VALUE AND STOCK MARKET PRICES}

\begin{abstract}
Jeffrey N. Gordon*
Between 1950 and 2005, the composition of large public company boards dramatically shifted towards independent directors, from approximately $20 \%$ independents to $75 \%$ independents. The standards for independence also became increasingly rigorous over the period. The available empirical evidence provides no convincing explanation for this change. This Article explains the trend in terms of two interrelated developments in U.S. political economy: first, the shift to shareholder value as the primary corporate objective; second, the greater informativeness of stock market prices. The overriding effect is to commit the firm to a shareholder wealth maximizing strategy as best measured by stock price performance. In this environment, independent directors are more valuable than insiders. They are less committed to management and its vision. Instead, they look to outside performance signals and are less captured by the internal perspective, which, as stock prices become more informative, becomes less valuable. More controversially, independent directors may supply a useful friction in the operation of control markets. Independent directors can also be more readily mobilized by legal standards to help provide the public goods of more accurate disclosure (which improves stock price informativeness) and better compliance with law. In the United States, independent directors have
\end{abstract}

* Alfred W. Bressler Professor of Law, Albert E. Cinelli Enterprise Professor of Law, Columbia Law School; Research Associate, European Corporate Governance Institute (jgordon@law.columbia.edu). For research assistance, many thanks to Ben Dickson, Nicolas Diefenbacher, Elysse Folk, Matt Jennejohn, Gary Li, Michael Horwitz, Adam Nelson, Jon Olsen, Jacob Oslick, Jason Sussman, and Benjamin Whetsell. For discussion and comments on prior drafts, many thanks to workshop participants at Columbia, Fordham, Georgetown, Stanford, and Virginia, and the American Association of Law Schools January 2007 Business Associations Section meeting, and to Bill Bratton, Jack Coffee, Larry Cunningham, Rob Daines, Deborah DeMott, Mel Eisenberg, Jill Fisch, Ron Gilson, Zohar Goshen, and Don Langevoort. 
become a complementary institution to an economy of firms directed to maximize shareholder value. Thus, the rise of independent directors and the associated corporate governance paradigm should be evaluated in terms of this overall conception of how to maximize social welfare.

INTRODUCTION. 1468

I. CHANGING BOARD COMPOSITION, 1950-2005: THE RISE OF

INDEPENDENT DIRECTORS AND DIRECTOR INDEPENDENCE ................... 1472

A. Changing Board Composition, 1950-2005 ................................... 1473

B. Mechanisms of Enhanced Director Independence, 1950-2005 .......... 1477

1. Relationship standards and rules ............................................. 1478

2. External sanctions and rewards ............................................. 1483

a. Sanctions (sticks) ........................................................ 1483

b. Rewards (carrots) ..................................................... 1487

c. Reputation.................................................................... 1488

3. Intra-board structures and functions ..................................... 1490

a. Board committees ....................................................... 1490

b. The "special committee" .............................................. 1493

c. Executive session; "lead director”" ........................................ 1494

4. Reducing CEO influence in director selection and retention ....... 1496

C. Summary of Part I.B .................................................................. 1499

II. CHANGING BOARD COMPOSITION: THE SEARCH FOR EVIDENCE THAT IT

MAKES A DIFFERENCE ..................................................................... 1500

A. Uncertain Effect on Firm Performance and Behavior...................... 1500

1. Firm performance tests ..................................................... 1500

2. Discrete task tests ............................................................ 1501

a. CEO terminations ......................................................... 1502

b. Takeover activity as target.............................................. 1502

c. Takeover activity as acquirer.......................................... 1503

d. Executive compensation................................................. 1503

e. Avoidance of financial fraud .............................................. 1504

3. Understanding the evidence .................................................. 1505

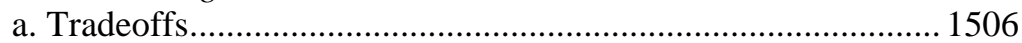

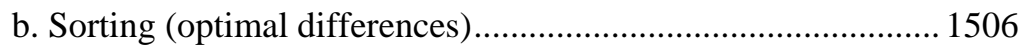

c. Diminishing marginal returns ........................................... 1507

d. Firm-specific vs. systematic effects................................. 1508

B. Summary of Parts I and II.................................................... 1509

III. THE RISE OF SHAREHOLDER VALUE, 1950-2005 ................................. 1510

A. The 1950s: The Heyday of Stakeholder Capitalism and Corporate

Managerialism ......................................................................... 1511

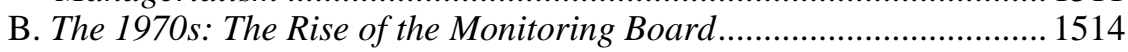

1. The Penn Central collapse and the absence of performance monitoring ............................................................................. 1515

2. "Questionable payments" and the absence of controls monitoring .......................................................................... 1516

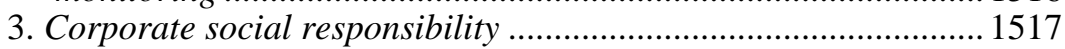

4. Reconceptualization of the board .......................................... 1518 
C. 1980s: The Takeover Movement, Shareholder Value, and the Rise of the Independent Director ...

1. The monitoring board as safe harbor in the "Deal Decade"....... 1520

2. Judicial promotion of director independence .................................. 1523

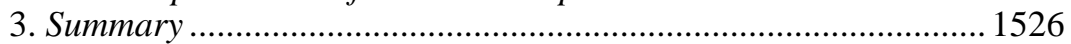

D. The 1990s: The Triumph of Shareholder Value and the Independent Board.

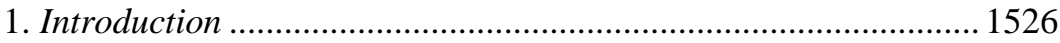

2. Shareholder value without hostile bids......................................... 1527

3. Resolving the paradox through the market for managerial services.

a. Executive compensation .......................................................... 1530

b. CEO termination...................................................................... 1531

c. Golden parachutes ................................................................. 1533

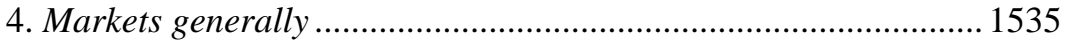

E. The 2000s: New Roles for Independent Directors and New

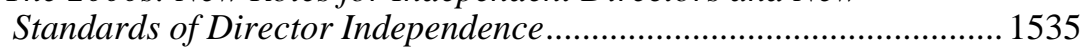

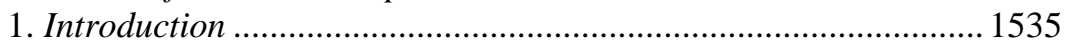

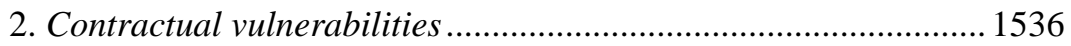

3. Contracting failures .................................................................. 1538

4. Director independence reconsidered .............................................. 1538

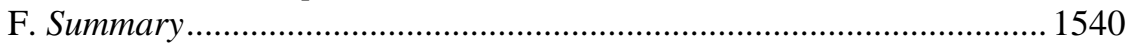

III. THE INCREASING INFORMATIVENESS OF STOCK PRICES, 1950-2005 ...... 1541

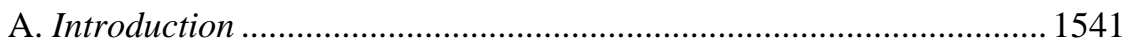

B. Market-Level Empirical Evidence on Stock Price Informativeness: Synchronicity and $R^{2}$.................................................................. 1543

C. Firm-Level Empirical Evidence of More Disclosure by Firms ............ 1545

D. Additional Disclosure Because of SEC Regulation ................................ 1548

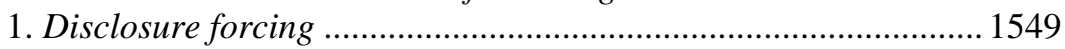

a. Disclosure integration............................................................. 1550

b. Segment reporting ............................................................... 1551

c. Management's discussion and analysis ................................... 1553

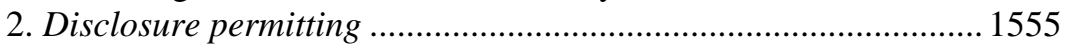

3. Disclosure standardizing ............................................................. 1557

E. Additional Disclosure Because of Accounting Pronouncements and

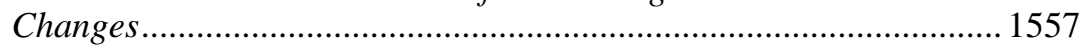

1. APB No. 22, Disclosure of Accounting Policies (1972) ................. 1558

2. SFAS No. 52, Foreign Currency Translation (1982)...................... 1559

3. SFAS No. 95, Statement of Cash Flows (1987) ............................. 1559

4. SFAS No. 106, Employers' Accounting for Post-Retirement

Benefits Other than Pensions (1990)............................................... 1560

F. Other Factors Enhancing the Informativeness of Stock Prices............ 1561

CONCLUSION: A NEW CORPORATE GOVERNANCE PARADIGM ........................ 1563

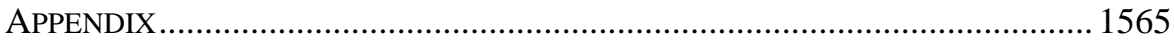




\section{INTRODUCTION}

"Independent directors"- that is the answer, but what is the question?

The now-conventional understanding of boards of directors in the diffusely held firm is that they reduce the agency costs associated with the separation of ownership and control. Elected by shareholders, directors are supposed to "monitor" the managers in view of shareholder interests. Who should serve on the board of a large public firm? Circa 1950, the answer was, as a normative and positive matter, that boards should consist of the firm's senior officers, some outsiders with deep connections with the firm (such as its banker or its senior outside lawyer), and a few directors who were nominally independent but handpicked by the CEO. Circa 2006, the answer is "independent directors," whose independence is buttressed by a range of rule-based and structural mechanisms. Inside directors are a dwindling fraction; the senior outside lawyer on the board is virtually an extinct species.

The move to independent directors, which began as a "good governance" exhortation, has become in some respects a mandatory element of corporate law. For controversial transactions, the Delaware courts condition their application of the lenient "business judgment rule" to board action undertaken by independent directors. ${ }^{1}$ The New York Stock Exchange requires most listed companies to have boards with a majority of independent directors ${ }^{2}$ and audit and compensation committees comprised solely of independent directors. ${ }^{3}$ The NASD requires that conflict transactions be approved by committees consisting solely of independent directors. ${ }^{4}$ Post-Enron federal legislation requires public companies to have an audit committee comprised solely of independent directors. ${ }^{5}$ But why has the move to independent directors been so pronounced?

One of the apparent puzzles in the empirical corporate governance literature is the lack of correlation between the presence of independent directors and the firm's economic performance. Various studies have searched in vain for an economically significant effect on the overall performance of the firm. Some would deny there is a puzzle: theory would predict that firms will select the board structure that enhances the chance for survival and success; if competitive market pressure eliminates out-of-equilibrium patterns of corporate governance, the remaining diversity is functional. Others would note that corporate governance in the United States is already quite good, and thus marginal improvements in a particular corporate governance mechanism would expectedly have a small, perhaps negligible, effect.

1. See infra text accompanying note 54 .

2. Unless the company has a 50\% shareholder. See infra text accompanying note 51.

3. See infra text accompanying notes $102,107$.

4. See infra note 115 .

5. See infra text accompanying note 102 . 
The claim of this Article is that the rise of independent directors in the diffusely held public firm is not driven only by the need to address the managerial agency problem at any particular firm. "Independent directors" is the answer to a different question: how do we govern firms so as to increase social welfare (as proxied by maximization of shareholder value across the general market)? This maximization of shareholder value may produce institutions that are suboptimal for particular firms but optimal for an economy of such firms. Independent directors as developed in the U.S. context solve three different problems: First, they enhance the fidelity of managers to shareholder objectives, as opposed to managerial interests or stakeholder interests. Second, they enhance the reliability of the firm's public disclosure, which makes stock market prices a more reliable signal for capital allocation and for the monitoring of managers at other firms as well as their own. Third, and more controversially, they provide a mechanism that binds the responsiveness of firms to stock market signals but in a bounded way. The turn to independent directors serves a view that stock market signals are the most reliable measure of firm performance and the best guide to allocation of capital in the economy, but that a "visible hand," namely, the independent board, is needed to balance the tendency of markets to overshoot.

This Article develops this general theme through an account of the changing function of the board over the past fifty years, from the post-World War II era to the present. During this period, the board's principal role shifted from the "advising board" to the "monitoring board," and director independence became correspondingly critical. Although other factors are at work, there were two main drivers of the monitoring model and genuine director independence. First, the corporate purpose evolved from stakeholder concerns that were an important element of 1950s managerialism to unalloyed shareholder wealth maximization in the 1990s and 2000s. Inside directors or affiliated outside directors were seen as conflicted in their capacity to insist on the primacy of shareholder interests; the expectations of director independence became increasingly stringent.

Second, fundamental changes in the information environment reworked the ratio of the firm's reliance on private information to its reliance on information impounded in prevailing stock market prices. Over the period, the central planning capabilities of the large public firm became suspect. Instead, a Hayekian spirit, embodied in the efficient capital market hypothesis, became predominant. ${ }^{6}$ The belief that markets "knew" more than the managers of any

6. See F. A. Hayek, The Use of Knowledge in Society, 35 Am. ECON. REv. 519 (1945). Hayek addresses the problem of the society's central planner, but his extolling of the superiority of the market in coordinating and guiding behavior becomes the ultimately successful critique of the planning capacities of the large firm heralded in books such as JoHn KenNeth Galbraith, THE NeW InduStRial State (4th ed. 1985):

The peculiar character of the problem of a rational economic order is determined precisely by the fact that the knowledge of the circumstances of which we must make use never exists in 
particular firm became increasingly credible as regulators and quasi-public standard setters required increasingly deep disclosure and this information was impounded in increasingly informative stock prices. The optimal boundaries of the firm changed as external capital markets advanced relative to internal capital markets in the allocation of capital. The richer public information environment changed the role of directors. Special access to private information became less important. Independent directors could use increasingly informative market prices to advise the CEO on strategy and evaluate its execution, as well as take advantage of the increasingly wellinformed opinions of securities analysts. Independents had positional advantages over inside directors, who were more likely to overvalue the firm's planning and capital allocation capabilities. In the trade-off between advising and monitoring, the monitoring of managers in light of market signals became more valuable. The reliability of the firm's public disclosures became more important. Indeed, by the end of the period, boards came to have a particular role in assuring that the firm provided accurate information to the market.

Thus, fidelity to shareholder value and to the utility of stock market signals found unity in the reliance on stock price maximization as the measure of managerial success. From a social point of view, maximizing shareholder value may be desirable if fidelity to the shareholder residual (as opposed to balancing among multiple claimants) leads to maximization of the social surplus. This is the shareholder primacy argument. Independently, maximizing shareholder value may be socially desirable if stock prices are so informative that following their signals leads to the best resource allocation. This is the market efficiency argument.

Over the period, boards eventually undertook measures that assured management's responsiveness to stock market signals, in particular through the use of stock-related compensation and retention decisions based on stock market performance. But there was an additional twist in the board's intermediation between managers and markets: the board, acting through the independent directors, came to have power to limit the potency of stock market signals in the takeover market. There was skepticism as to whether markets were perfect, even at the height of the prestige of the efficient capital market hypothesis. After the 1987 stock market crash, economists developed increasingly more persuasive accounts of how stock market prices-even though, on average, the best estimate of intrinsic value - could deviate for a substantial time period from economic fundamentals. The board gained power under state law to hinder the operation of the takeover market, i.e., to weigh the reliability of the market price as a measure of shareholder value at a particular time. The problem is this: given the imperfection of market prices, what is the

concentrated or integrated form, but solely as the dispersed bits of incomplete and frequently contradictory knowledge which all the separate individuals possess.

Hayek, supra, at 519. 
optimal degree of responsiveness to price changes, not just for any particular firm but across the entire economy? Investors may optimally adjust portfolios of liquid financial assets on one time line; managers may optimally adjust internal investment decisions over real assets on another. In light of potentially negative systematic effects from quick responses in the takeover market to imperfect market signals, it may be optimal to have a firm-specific institution that could slow the pace of control market activity to test the market for price reversals. The "visible hand" of the well-functioning board could, in theory, serve this function.

Independent directors have a comparative advantage for these different tasks. They are less dependent on the CEO and more sensitive to external assessments of their performance as directors; they are less wedded to inside accounts of the firm's prospects and less worried about the disclosure of potentially competitively sensitive information. They also have credibility in the "checking" of market signals against intrinsic measures of the firm's prospects. In other words, genuinely independent directors might create significant value in the allocation of resources, not just in their firm but more generally as other firms are forced to adapt to the best performers. Thus, one of the hallmarks of the period was the development of various mechanisms of director independence aimed at producing directors who were independent in fact.

This emphasis on the critical role of independent directors as an efficiencyjustified strategy for importing stock market signals into the firm's (and the economy's) decisionmaking will strike some as a radical interpretation of the history. I make no claim that the various actors have been fully aware of the implications of each step-much may have happened through inadvertence, and the role of independent directors could have been otherwise- but this is the end point of this non-teleological process.

This Article proceeds as follows. Part I reviews the overall trend of board composition of large U.S. public companies since 1950. On the basis of data assembled from a number of different sources, the fraction of independent directors for large public firms has shifted from approximately $20 \%$ in the 1950s to approximately $75 \%$ by the mid-2000s. Part I also reviews the strengthening of various mechanisms of director independence that enhanced the independence-in-fact of directors over the period. Part II surveys the empirical studies that fail to find significant economic effects from this pronounced move toward director independence and concludes that the studies are looking in the wrong place. The studies look at board composition differences across firms. Yet if the main advantage of independent directors is to help commit firms throughout the economy to a shareholder wealth maximization strategy, then systematic effects will swamp cross-sectional variation. ${ }^{7}$ Part III non-exhaustively canvasses the $1950-2005$ period to explore

7. This generalizes the argument made regarding hostile takeovers: that ultimately 
one important driver in changing board composition: the shift toward shareholder wealth maximization as the dominant corporate purpose. Director independence became linked to the monitoring of managerial performance in order to serve shareholder ends. Part III also traces a complementary development: managers who once vigorously resisted board independence as a limitation to their autonomy came to champion the independent board as a buffer from the hostile takeover and as a substitute for greater government intervention in the wake of scandals.

Part IV non-exhaustively canvasses the 1950-2005 period to explore another driver of the change in board composition: the increasing informativeness and value of stock market signals. Informativeness was enhanced by increased disclosure resulting from regulatory initiatives by the Securities and Exchange Commission and the quasi-public accounting standards setting authorities. New information processing technology and increasing investments in securities analysis helped make prices more informative as well. It's not that the disclosure system changed to accommodate a demand for independent directors. Rather, as stock prices became more informative, the concern about the independents' potential debility — their lack of a well-informed view about the firm—subsided. Indeed, an increasingly important element of the independent board's monitoring role came to be the appropriate use of market signals in executive compensation contracts and in CEO termination decisions. Additionally, directors came to have an increasingly important function in assuring the accuracy of the firm's financial disclosure, i.e., "controls monitoring."

Part V concludes with the suggestion that the rise of independent directors, at least in the United States, is tied to a new corporate governance paradigm that looks to the stock price as the measure of most things. Maximizing the stock price serves two normative ends: promoting the interests of shareholders and making use of the information impounded by the market to allocate capital efficiently. In this time of increased shareholder activism, one important question is whether the enhanced independence of directors will create a space for a public firm to resist stock market pressure in the pursuit of currently disfavored business strategies (and whether this would be desirable) or whether the very pressures that give rise to director independence will in the end swamp this possibility.

\section{CHANGING BOARD COMPOSITION, 1950-2005: THE RISE OF INDEPENDENT DIRECTORS AND DIRECTOR INDEPENDENCE}

One of the most important empirical developments in U.S. corporate governance over the past half century has been the shift in board composition

their benefits (costs) are not adequately reckoned by summing bidder and acquirer gains (losses), but rather in the systematic effects from a robust market in corporate control. 
away from insiders (and affiliated directors) toward independent directors. This trend is consistent throughout the period and accelerates in the post-1970 subperiod. This Part describes the trend, looking at a number of studies that use different samples of firms and that apply somewhat different definitions of "independence." In addition to the numerical shift, the independence-in-fact of directors has been buttressed in the post-1970 period by a series of rule-based and structural mechanisms. In its own way, the effort to create independencein-fact is as striking as the numerical shift.

\section{A. Changing Board Composition, 1950-2005}

No single study traces the rise of independent directors over the 1950-2005 period. The study that best captures the changing board composition over the period is Lehn, Patro and Zhao's paper reporting the insider-outsider breakdown for all publicly traded U.S. firms that survived from 1935 through 2000, namely eighty-one predominantly large firms. ${ }^{8}$ Lehn et al. find a consistent decline in the average percentage of insiders over the 1950-2000 period, from approximately $50 \%$ to approximately $15 \%$, with accelerating change after $1970 .{ }^{9}$ The available data, however, apparently do not readily

8. Kenneth Lehn et al., Determinants of the Size and Structure of Corporate Boards: 1935-2000 (Nov. 2003) (unpublished manuscript), available at http://ssrn.com/ abstract $=470675$. They describe their sample as all firms in the Center for Research on Security Prices (CRSP) database which survive over the period and for which data are also available in the Moody's Industrial Manual. Id. (manuscript at 12). The sample of course imperfectly represents the universe of firms existing at any point in time and tilts toward the largest firms. Id. Interestingly, the fraction of insiders monotonically increases over the $1935-1950$ period, from approximately $45 \%$ to $50 \%$. Id. (manuscript at 36 tbl.1 panel C) (presenting descriptive statistics of sample firms with five-year frequency). The abovementioned survivorship bias in the sample suggests an adaptive quality in the shift away from insiders and toward independent directors in the post-1950 period.

9. This table, drawn from the Lehn et al. data, describes the shift over the period. Percent change is based on my own calculations.

\begin{tabular}{ccc}
\multicolumn{3}{c}{ Percentage of Inside Directors, 1950-2000 } \\
\hline \hline Year & Mean & Decade-to-decade percent change \\
\hline 1950 & $49 \%$ & $\mathrm{n} / \mathrm{a}$ \\
1955 & $47 \%$ & \\
1960 & $43 \%$ & $-12 \%$ \\
1965 & $42 \%$ & $-5 \%$ \\
1970 & $41 \%$ & \\
1975 & $39 \%$ & $-20 \%$ \\
1980 & $33 \%$ & \\
1985 & $30 \%$ & $-21 \%$ \\
1990 & $26 \%$ & \\
1995 & $21 \%$ & $-38 \%$ \\
2000 & $16 \%$ & \\
\hline
\end{tabular}


Figure 1. Board Composition, 1950-2005

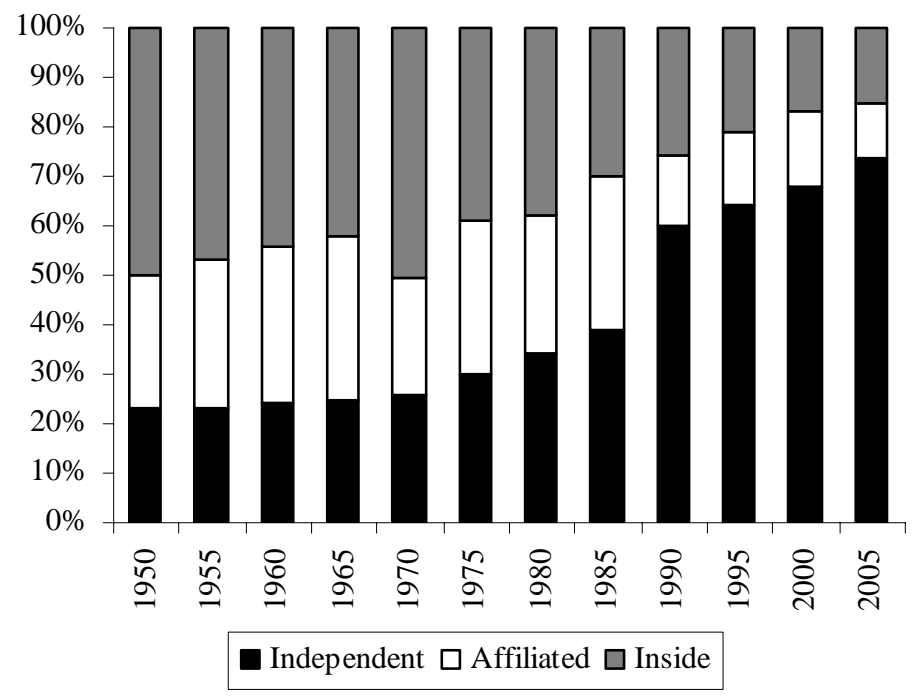

Source: Year values (means) are derived from various sources. See infra Appendix Table 1. Data are from every five years; where multiple data points existed (including for immediately adjacent years), data were averaged to create a single value. Off-year values are not shown. For a statistical trendline, see infra Figure 2.

permit a further breakdown of the "outside" directors into "affiliated" and "independent" directors over the entire period. Other studies, typically crosssectional in nature, examine proxy filings to classify directors. The earliest such study was in $1970 .{ }^{10}$ The Securities and Exchange Commission (SEC) did a detailed survey covering 1977-1978, ${ }^{11}$ the academic studies began in 1985, and the Investor Responsibility Research Center began its database for approximately 1500 public firms in $1996 .^{12}$

I have put together these studies to construct a "time series" showing the board composition trend over the $1950-2005$ period, ${ }^{13}$ which is depicted

10. Ephraim P. Smith, Interlocking Directorates Among the 'Fortune 500,' 3 ANTITRUST L. \& ECON. REV., Summer 1970, at 47, 48 (assessing board composition as sidelight to director interlocks).

11. S. Comm. on Banking, Housing, and Urban AfFairs, 96th Cong., SEC Staff Report on Corporate AcCountability 590-98, 598 tbl.2 (Comm. Print 1980) [hereinafter SEC STAFF REPORT] (surveying 1200 major firms drawn from NYSE, Amex, Nasdaq, and OTC/regional exchanges in 1978-79). The SEC study led to a rule proposal, subsequently withdrawn, that would have required precise categorization of the outside directors.

12. See Institutional Shareholder Servs. (ISS), Board Practices/Board Pay 2006, at 1 (2006) (describing database compilation). (The Investor Responsibility Research Center was acquired by ISS in 2005.)

13. See infra Appendix Table 1. Perhaps the right metaphor is to think of these figures 
Figure 2. Changing Proportion of Inside and Independent Directors, 1950-2005

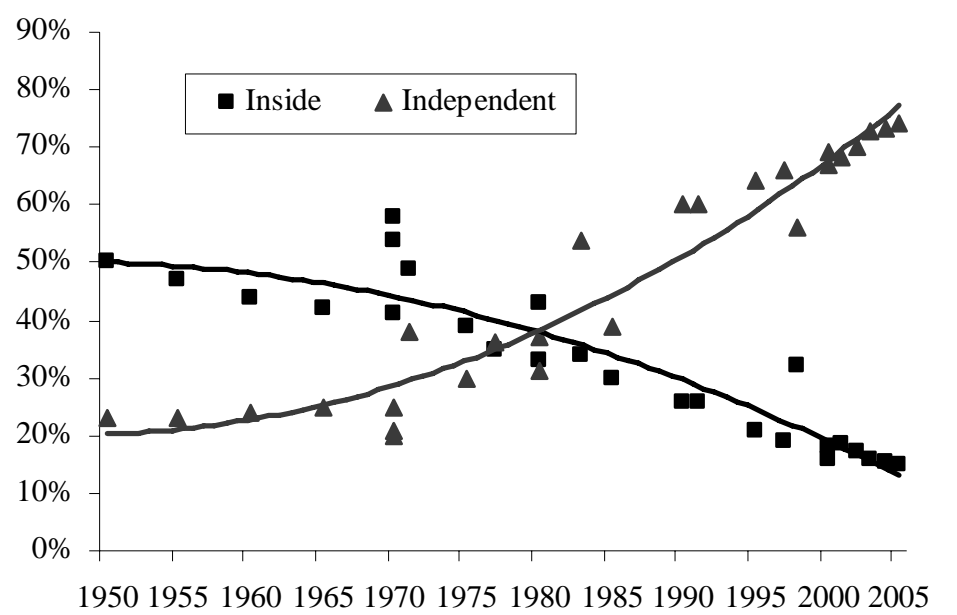

Source: Values are derived from various sources. See infra Appendix Table 1. The trend line is produced using the polynomial-fitting command in Excel.

graphically in Figures 1 and 2. ${ }^{14}$ These figures show a steady increase in the representation of independent directors on the board, from approximately $20 \%$ in 1950 to approximately $75 \%$ in 2005 . This is a powerful change in board composition that calls out for an explanation.

The limitations of this demonstration are obvious: I have used crosssectional studies to reclassify the Lehn et al. category of "outsiders" into the more useful "affiliated" and "independent" categories, assuming in particular that the 1970 breakdown of outsiders is applicable to the 1950-1970 period for which there are no earlier cross-sectional studies. (In light of the history discussed below, it is likely that this overstates the fraction of independents on pre-1970 boards, which thus understates the change over the period.) Also, the various studies used different samples and undoubtedly applied different criteria in coding proxy disclosure about directors into the relevant classifications. These classification decisions would have been influenced by whether the researcher was trying to assess whether non-insiders augmented the corporation's capacities (thus referring to affiliated directors as "instrumental" directors) ${ }^{15}$ or enhanced monitoring (calling affiliated directors "grey"

as "snapshots on a string."

14. Figure 1 shows the assembled data in five-year increments. Figure 2 shows all data points and trend lines graphed using the Excel polynomial-fitting command.

15. E.g., Barry D. Baysinger \& Henry N. Butler, Corporate Governance and the Board of Directors: Performance Effects of Changes in Board Composition, 1 J.L. ECON. \& ORG. 101, 110 (1985). 
directors). ${ }^{16}$ Notwithstanding the inevitable noise, the overall trend that emerges is quite striking, as reflected by Figure 1 and by the fitted curves of Figure 2.

There has been an additional trend in the latter part of the period toward what Bhagat and Black call "supermajority" independent boards. ${ }^{17}$ As recently as 1989 , boards with only one or two insiders were unheard of. In a Korn/Ferry 1989 survey of large public companies, 67.5\% reported three insiders and $32.5 \%$ reported four insiders. ${ }^{18}$ By 2003, the pattern was strikingly different: $65 \%$ reported two or fewer insiders; $35 \%$ reported three insiders; none reported more than three insiders. ${ }^{19}$ By 2004, under the influence of Sarbanes-Oxley and the stock exchange listing rules, the shift was virtually complete: $91 \%$ reported two or fewer insiders; $9 \%$ reported three insiders. ${ }^{20}$ Large public firms have moved to a pattern of one, perhaps two, inside directors and an increasing number of independent directors. Some academics and practitioners have characterized the emerging pattern as the cynosure of corporate governance because of its maximum control of managerial agency costs. ${ }^{21}$

16. E.g., Benjamin E. Hermalin \& Michael S. Weisbach, The Determinants of Board Composition, 19 RAND J. ECON. 589, 591 (1988).

17. Sanjai Bhagat \& Bernard Black, The Non-Correlation Between Board Independence and Long-Term Firm Performance, 27 J. CORP. L. 231, 239 (2002).

18. Korn/Ferry InT'L, BoARd of Directors SixteEnTH ANNuAl Study 1989, at 15, 25 (1989) (Diefenbacher calculations based on survey data). The largest firms reported four insiders on average. $I d$. at 15.

19. Korn/Ferry InT'L, 30Th ANNUAL BoARd OF Directors Study 2003, at 8-9 (2003); KorN/FERRY InT’L, 30TH ANNUAL STUDY SupPlEMENT 12 (2004) (reporting 20022003 proxy data and Diefenbacher calculations).

20. Korn/FERry InT’L, 31st ANNUAL BoARD OF Directors StUdy 2004, at 10 (2004) (reporting 2003-2004 proxy data and Diefenbacher calculations); see also Bus. Roundtable, Business Roundtable Corporate Governance Survey: Key Findings (2006), available at http://www.businessroundtable.org/publications/publication.aspx?qs= 2AC6BF807822B0F1AD34484 (reporting that 85\% of its approximately 160 members expect to have a board in 2006 consisting of at least 80\% independent directors, 98\% expect that their boards will be at least $60 \%$ independent, and $42 \%$ expect an entirely independent board); SHEARMAn \& Sterling LLP, TRENDS In THE CoRPORATE GOVERnANCE PRACTICES OF THE 100 LARGEST US PUBLIC COMPANIES 4 (2005), available at http://www.shearman.com/cg_survey05/ (reporting that independent directors comprised $75 \%$ or more of the board of eighty-one of the top 100 companies in 2004 and 2005 and that the CEO was the only non-independent director of thirty-seven of the top 100 companies in 2005).

21. See, e.g., Michael C. Jensen, The Modern Industrial Revolution, Exit, and the Failure of Internal Control Systems, 48 J. FIN. 831, 865 (1993); Martin Lipton \& Jay W. Lorsch, A Modest Proposal for Improved Corporate Governance, 48 Bus. LAw. 59, 67-68 (1992) (recommending a board size of eight or nine directors, comprised of at least two independent directors for every one insider or affiliate, and arguing that "five or six independent directors, who are carefully selected, should provide the breadth of perspective and diversity required"). 


\section{B. Mechanisms of Enhanced Director Independence, 1950-2005}

The preceding section described the long-term numerical trend away from inside directors and toward independents. Nominally independent directors can of course be passive, ineffectual, and otherwise be found in management's pocket, as famously described in Myles Mace's 1971 book..$^{22}$ In 1989, nearly two decades later, Jay W. Lorsch and Elizabeth MacIver argued that the independent director was still more likely to be a "pawn" than a "potentate." 23 Nevertheless, one of the striking elements of the 1950-2005 period was the development of various mechanisms to create and enhance the independence of directors. The genesis of many of these mechanisms was the 1970s wave of corporate governance reform, which tried to establish preconditions for the monitoring board. Indeed, "independent director" entered the corporate governance lexicon only in the 1970s as the kind of director capable of fulfilling the monitoring role. Until then, the board was divided into "inside" and "outside" directors. ${ }^{24}$ Further developments favoring director independence occurred in the 1990s as part of the post-hostile bid settlement among institutional investors, managers, and boards. ${ }^{25}$ The last wave, post-2002, was spurred by the Enron, WorldCom, and other board failures, which led to new efforts to strengthen director independence in light of the board's additional role of controls monitoring as well as performance monitoring.

Analytically, these mechanisms of director independence can be broken down into four categories: (1) tightening the standards and rules of disqualifying relationships; (2) increasing negative and positive sanctions, such as legal liability for fiduciary duty breach, reputational sanctions, and stockbased compensation; (3) development of intra-board structures, such as taskspecific committees and designation of a "lead director"; and (4) reducing CEO influence in director selection and retention by, for example, the creation of a nominating committee staffed solely by independent directors. Without being Panglossian, it does seem that the accumulating effects of changes in each of these mechanisms, as well as the accumulating cultural shift fostered by the

22. Myles L. Mace, Directors: Myth And Reality 108 (1971); see also Laura Lin, The Effectiveness of Outside Directors as a Corporate Governance Mechanism: Theories and Evidence, 90 Nw. U. L. REv. 898, 898-903, 912-17 (1996) (discussing the "managerial hegemony" theory which asserts that management controls the board regardless of its composition).

23. Jay W. Lorsch with Elizabeth Maciver, Pawns or Potentates: The Reality OF AMERICA'S CORPORATE BOARDS (1989).

24. Professor Mitchell argues that the principal role of the pre-1970s outside director was to provide cover for conflict transactions entered into by insiders and to provide a liability shield for insiders in other respects. He also suggests that this function still continues. See Lawrence E. Mitchell, The Trouble with Boards (Sept. 9, 2005) (unpublished manuscript, on file with author).

25. See infra text accompanying notes 103-06, 256-58. 
successive reform efforts, should have increased the independence-in-fact of directors over the period.

\section{Relationship standards and rules}

A straightforward way to strengthen director independence is to select candidates who have no ongoing (or even prior) relationship with the corporation other than as a director. Over the 1950-2005 period the relationship measure of independence tightened considerably. Initially the relationship test focused narrowly on the director's employment status. Those who were not current officers were, by definition, outsiders, ${ }^{26}$ including non-executive directors who had what would be regarded today as a disqualifying material relationship—such as employment with a supplier or a customer, or with the firm's investment bank or law firm. ${ }^{27}$ This consensus was reflected by the 1962 New York Stock Exchange statement that accepted a description of an outside director as simply one who is non-management. ${ }^{28}$

Standards tightened considerably in the wake of the 1970s corporate governance crisis, which for the first time produced a concerted demand for "independent" directors. The well-publicized business failures of the period led to increasing acceptance of the "monitoring model" of the board, which required independent directors. ${ }^{29}$ The contemporaneous revelations of widespread corporate bribery and illegal campaign contributions at home and

26. Stanley C. Vance, Functional Control and Corporate Performance in Large-Scale Industrial Enterprise (1955) (unpublished manuscript) (described in Stanley C. Vance, Corporate Governance: Assessing Corporate Performance by Boardroom Attributes, $6 \mathrm{~J}$. BUS. RES. 203, 204-05 (1978)).

27. See, e.g., Conference Bd., Corporate Directorship Practices 17 (1959) (describing "officers of creditor banks and insurance companies or of financial institutions that regularly serve the company, and the corporate counsel” as outsiders).

28. N.Y. STOCK EXCh., The Corporate Director AND the Investing Public 7, 1920 (1962); see also Stanley C. VANCE, BoArds of Directors: Structure and PERFORMANCE 5 (1964) (defining outsiders as those who "have no significant personal holdings in the company even though they are associated with banks, brokerage firms, insurance companies, and other investment companies;.... are executives of other organizations; or ... are primarily public figures”). This was a view apparently held by academics as well. See Jeffrey Pfeffer, Size and Composition of Corporate Boards of Directors: The Organization and Its Environment, 17 ADMIN. SCI. Q. 218, 219 n.6 (1972) ("Inside directors are directors who are currently involved in the management of the organization and, in some definitions, former executives as well. . . Outside directors do not have a direct management relationship with the organization.”). See generally JEREMY Bacon \& James K. Brown, Conference Bd., Corporate Directorship Practices: Role, SELECTION AND LEgAL STATUS OF THE BOARD (1975) (classifying non-officer directors as "outside" even though they are chosen by management).

29. See infra notes 207-14 and accompanying text. The "monitoring model" was promoted most notably by MELVIN A. EISENBERG, THE STRUCTURE OF THE CORPORATION: A LEGAL ANALYSIS 162-70 (1976). 
abroad, so-called "questionable payments," spurred the SEC to insist on independent directors in the settlement of various enforcement actions. ${ }^{30}$

The unresolved question was what exactly constituted "independence"how should one deal with economic interests and personal ties that would potentially undercut independence. Federal regulatory guidance, stock exchange listing standards, state fiduciary law, and "best practice" pronouncements have all played a role in line-drawing.

The 1978 Corporate Director's Guidebook, an influential product of mainstream corporate lawyers, drew a two-level distinction: first distinguishing between "management" and "non-management" directors, and then between affiliated and non-affiliated non-management directors. ${ }^{31}$ A former officer or employee was to be regarded as a managerial director. A director with other economic or personal ties "which could be viewed as interfering with the exercise of independent judgment” was an affiliated non-managerial directorfor example, "commercial bankers, investment bankers, attorneys, and others who supply services or goods to the corporation."32

In 1978, the SEC went so far as to propose proxy disclosure that would categorize outside directors as "affiliated" or "independent, with the obvious intention of using disclosure to obtain Chairman Harold Williams' objective of boards staffed principally, if not entirely, by independent directors. ${ }^{33}$ In response to corporate objections, it rapidly withdrew the proposal, ${ }^{34}$ lamely explaining that "the ability to exercise independent judgment is not solely dependent upon the label attached to a particular director." ${ }^{\text {,3 }}$ On the NYSE front, its 1977 audit committee listing standard, which required staffing by "directors independent of management," split the difference: it permitted

30. See, e.g., Arthur F. Mathews, Recent Trends in SEC Requested Ancillary Relief in SEC Level Injunctive Actions, 31 Bus. LAw. 1323, 1326-28, 1334-35 (1976). The SEC also insisted on other corporate governance measures, such as the creation of audit committees and special committees. For a contemporaneous skeptical account of the effectiveness of these corporate governance elements in particular consent decrees, see Lewis D. Solomon, Restructuring the Corporate Board of Directors: Fond Hope-Faint Promise?, 76 MicH. L. REV. 581 (1978).

31. ABA Comm. on Corporate Laws, Corporate Director's Guidebook, 33 Bus. LAw. 1591, 1619-20 (1978).

32. Id. at 1620 .

33. Proposed Rules Relating to Shareholder Communications, Shareholder Participation in the Corporate Electoral Process and Corporate Governance Generally, Exchange Act Release No. 14,970, 15 SEC Docket 291 (July 18, 1978); see Harold M. Williams, Corporate Accountability, in COMMENTARIES ON CORPORATE STRUCTURE AND GOVERNANCE 513 (Donald E. Schwartz ed., 1979).

34. Shareholder Communications, Shareholder Participation in the Corporate Electoral Process and Corporate Governance Generally, Exchange Act Release No. 15,384, Investment Company Act Release No. 10,510, 16 SEC Docket 348 (Dec. 6, 1978).

35. SEC STAFF REPORT, supra note 11, at 469. A survey of the 1978-1979 proxy season undertaken in connection with the proposal revealed that nearly $30 \%$ of "outside" directors were in fact "affiliated" and thus not "independent." See id. at 598 tbl.2 (surveying 1200 major firms drawn from the NYSE, Amex, Nasdaq, and OTC/regional exchanges). 
directors from organizations with "customary commercial, industrial, banking, or underwriting relationships with the company" to serve on an audit committee unless the board found that such relationships "would interfere with the exercise of independent judgment as a committee member." ${ }^{36}$ That definition remained intact until 1999, when the criterion of audit committee independence was significantly tightened in response to the prodding of the Blue Ribbon Committee on Improving Audit Committee Effectiveness. Audit committees were required to consist of at least three "independent directors," and the "customary" economic relationships of the 1977 were now off limits for committee members. ${ }^{37}$

Another federal regulatory tightening of the "independence" standard came through the 1996 IRS criteria for "outside" directors who could approve performance-based remuneration that was excepted from the \$1 million deductibility cap on executive compensation established by section $162(\mathrm{~m})$ of the Internal Revenue Code. ${ }^{38}$ Those criteria disqualified a former officer of the corporation and a director who receives remuneration from the corporation "either directly or indirectly, in any capacity other than as a director." 39 The criteria also place stringent limits on the extent to which the director could have an ownership interest in or be employed by an entity that received payments from the corporation. ${ }^{40}$ In turn, the IRS regulations influenced the SEC's 1996 rules specifying independent director approval of certain stock-related transactions as a condition of exemption from the short-swing profit recapture provisions of section 16(b) of the 1934 Securities Exchange Act. ${ }^{41}$ The definition of a "non-employee director" with such approval power followed the substance of the IRS regulation. ${ }^{42}$ The tests of economic distance for director

36. NYSE, Inc., Listed Company Manual § 303 \& supp. (1983) (embodying Proposed Rule Change by Self-Regulatory Organizations, 42 Fed. Reg. 8737 (Feb. 11, 1977), and Order Approving Proposed Rule Change, 42 Fed. Reg. 14,793 (Mar. 16, 1977)).

37. See April Klein, Likely Effects of Stock Exchange Governance Proposals and Sarbanes-Oxley on Corporate Boards and Financial Reporting, 17 ACCT. HoRIZONS 343, 346 \& tbl.1 (2003); NYSE, Inc., NYSE Corporate Accountability and Listing Standards Committee 6 n.2, 7 n.3 (2002).

38. 26 U.S.C. § 162(m) (2007). The code provision was added as part of the Omnibus Budget Reconciliation Act of 1993, Pub. L. No. 103-66, § 13211, 107 Stat. 312, which became effective as of January 1, 1994. The provision required the setting of performance goals by a compensation committee "which is compromised solely of 2 or more outside directors.” 26 U.S.C. § 162(m)(4)(C)(i) (2007). The compensation committee then needs to "certif[y] that the performance goals and any other materials terms were in fact satisfied." Id. $\S 162(\mathrm{~m})(4)(\mathrm{C})(\mathrm{iii})$.

39. Treas. Reg. § 1.162-27(e)(3)(i) (1995).

40. The regulations include a $\$ 60,000$ "de minimis" exception for payments to an entity where the director is a minority owner or employee.” Id. § 1.162-27(e)(3)(ii)-(iii).

41. Ownership Reports and Trading by Officers, Directors and Principal Security Holders, Exchange Act Release No. 37,260, Investment Company Act Release No. 21,997, 62 SEC Docket 138 (May 31, 1996).

42. 17 C.F.R. § 240.16b-3(b)(3) (2007). This regulation also includes a quantitatively similar de minimis exception for consulting arrangements. 
independence established by these two important federal regulatory agencies were important benchmarks. ${ }^{43}$

State courts grappling with the right of shareholders (as opposed to the board) to maintain derivative litigation alleging corporate wrongdoing were another important source of heightened standards of director independence midway in the period. The "questionable payments" scandal of the 1970s led to a spate of shareholder derivative suits. Corporations sought to take control of the actions to avoid their potentially disruptive effects and to eliminate alleged "strike suits." In the important decision of Zapata Corp. v. Maldonado, ${ }^{44}$ the Delaware Supreme Court held that even for a "demand-excused" derivative action, a "special committee" constituted of independent directors could nevertheless obtain dismissal of the action if it demonstrated this was in the best interests of the corporation. In its dismissal request, the special committee had the burden of demonstrating its independence. This, of course, increased the demand for directors with minimal prior connection to the corporation and its management, and helped ratchet up the independence standard. Moreover, the standards developed in derivative litigation in the 1970s and early 1980s also set criteria for the bona fides of directors who needed judicial sanction for their approval of target defensive measures in the face of a hostile bid. ${ }^{45}$

Throughout the 1980s and 1990s, various panels and "blue ribbon" committees developed somewhat influential "best practice" guidelines for relationship tests. The most important exposition, the American Law Institute's (“ALI's") 1992 Principles of Corporate Governance, recommended that the board of a public corporation "should have a majority of directors who are free of any significant relationship with the corporation's senior executives."46 "Significant relationship" was defined in a way to disqualify many affiliated directors, both through categorical exclusions relating to the firm's principal outside law firm or investment bank, and through attention to customer/supplier relationships crossing a relatively low $(\$ 200,000)$ economic materiality threshold. ${ }^{47}$ The Principles of Corporate Governance also called for the firm’s nominating committee to engage in a more individualized review of factors that

43. Additionally, as part of its 1992 executive compensation disclosure rules, the SEC established similar independence standards. The standards were not mandatory for compensation committee members; rather, disclosure was required of directors who did not meet the standards. See Executive Compensation Disclosure, Securities Act Release No. 6962, Exchange Act Release No. 31,327, Investment Company Act Release No. 19,032, 52 SEC Docket 1961 (Oct. 16, 1992) (currently reflected in Regulation S-K Item 402(j)). 1979).

44. 430 A.2d 779 (Del. 1981); see also Auerbach v. Bennett, 393 N.E.2d 994 (N.Y.

45. See cases cited infra note 49.

46. Am. LAW Inst., Principles of CoRporate Governance: ANAlysis and RECOMMENDATIONS § 3A.01 (1994) [hereinafter ALI PRINCIPLES] (as adopted and promulgated in 1992); see also NAT'L AsS'N OF CORPORATE DiRS., REPORT OF THE NACD Blue RiBBon COMMISSION ON DiRECTOR PROFESSIONALISM 9-10 (1996).

47. ALI PRINCIPLES, supra note 46, § 1.34. 
could undermine the independence of particular directors. ${ }^{48}$ The ALI project had influence beginning in 1982 with its tentative first draft, whose "significant relationship" test was similar to the final version. ${ }^{49}$

Ultimately, the Enron corporate reform wave at the end of the period worked a sea change. ${ }^{50}$ Seeking to avoid corporate governance legislation, the NYSE in 2002 initiated a significant revision of its board composition standards. A majority of directors were required to be independent, and stringent independence criteria applied to all such directors, not just audit committee members. ${ }^{51}$ Under prodding from institutional investors, issuers, and the SEC, the NYSE revised the proposals over a yearlong period, adding and subtracting stringency. The 2004 version (as further refined) contains a

48. Id. § 3A.01 cmt. d.

49. See Stephen M. Bainbridge, Independent Directors and the ALI Corporate Governance Project, 61 GEO. WASH. L. REV. 1034, 1035 n.6 (1993). Many claimed-with good reason-that reliance on nominal markers of independence was superficial, arguing that psychological and social fellow-feeling among the class of people chosen as directors creates a "structural bias" that undercuts true independence. See, e.g., EISENBERG, supra note 29, at 146; James D. Cox \& Donald E. Schwartz, The Business Judgment Rule in the Context of Termination of Derivative Suits by Independent Committees, 61 N.C. L. REV. 541, 542-43 (1983) (describing structural bias as "a predisposition toward the defendant because the members who serve on the special litigation committee have a common cultural bond with the defendants on whom they are passing judgment"). Whatever its reality, the "structural bias" objection to director independence has been rejected by most courts in most instances where independence-in-fact has been challenged. See, e.g., Beam v. Stewart, 845 A.2d 1040, 1050-52 (Del. 2004); Aronson v. Lewis, 473 A.2d 805, 815 n.8 (Del. 1984). But cf. Miller v. Register \& Tribune Syndicate, Inc., 336 N.W.2d 709, 716 (Iowa 1983) (noting that potential for structural bias leads to greater judicial scrutiny). Courts seemed to take "disinterestedness" plus nominal independence, as defined by then-applicable criteria, as sufficient for the purpose. E.g., Beam, 845 A.2d at 1050 (holding that "[a]llegations of mere personal friendship or a mere outside business relationship, standing alone, are insufficient to raise a reasonable doubt about a director's independence"). There might be some disagreement between the Delaware Supreme Court and the Delaware Chancery Court, which has examined independence more searchingly. See In re Oracle Corp., 824 A.2d 917, 939-42 (Del. Ch. 2003) (deciding that professors did not satisfy independence standards for special committee and adopting a contextual approach); Orman v. Cullman, 794 A.2d 5, 25 n.50 (Del. Ch. 2003) (explaining that independence turns on whether a director's decision is "controlled by another," such as from domination "through close personal or familial relationship or though force of will," or if the director is "beholden” to the controller because of that party's unilateral power to decide whether the director will receive a significant enough benefit). See generally Julian Velasco, Structural Bias and the Need for Substantive Review, 82 WASH. U. L.Q. 821 (2004) (exploring the courts' response to structural bias and proposing a standard of review of the substantive merits of directors' decisions).

50. See Stephen M. Bainbridge, A Critique of the NYSE's Director Independence Listing Standards (UCLA Sch. of Law Research Paper Series, Paper No. 02-15, 2002), available at http://ssrn.com/abstract=317121.

51. NYSE, Inc., Corporate Governance Rule Proposals Reflecting Recommendations from the NYSE Corporate Accountability and Listing Standards Committee as Approved by the NYSE Board of Directors, August 1, 2002 (2002), available at http://www.nyse.com/ pdfs/corp_gov_pro_b.pdf. The majority independent directors requirement does not apply to a company with a $50 \%$ shareholder, though the independent audit committee requirement does. Id. 
general standard requiring an affirmative board determination that a purportedly independent director has "no material relationship with the listed company" (including "as a partner, shareholder or officer of an organization that has a relationship with the company"). ${ }^{52}$ It also has a series of carefully defined exclusions and safe harbors that cover in detail the effect of prior employment, familial ties, consulting relationships, and charitable ties. And, of course, the SEC, exercising regulatory authority under Sarbanes-Oxley, specified minimum conditions in 2003 for director independence for directors who serve on the audit committee. ${ }^{53}$

\section{External sanctions and rewards}

A different mechanism for director independence focuses on incentivessanctions and rewards, sticks and carrots-for particular director behavior. Most commonly these are economic, but reputation matters too.

\section{a. Sanctions (sticks)}

The most potent stick during the period was the risk of monetary liability for breach of various duties under state fiduciary law and the federal securities law; both sets of duties foster director independence by requiring director attention to the business and affairs of the corporation, a precondition to the exercise of independent judgment. ${ }^{54}$ But how real was such liability exposure?

52. See NYSE, Inc., Listed Company Manual § 303A.02 (2007); see also NYSE, Inc., NYSE Listed Company Manual Section 303A Corporate Governance Listing Standards Frequently Asked Questions (Feb. 13, 2004), available at http://www.nyse.com/pdfs/ section303Afaqs.pdf.

53. See Standards Relating to Listed Company Audit Committees, Securities Act Release No. 8220, Exchange Act Release No. 47,654, Investment Company Act Release No. 26,001, 79 SEC Docket 2876 (Apr. 9, 2003); 17 C.F.R. § 240.10A-3(b) (2007) (codifying Exchange Act Rule 10A-3(b)).

54. The traditional formulation of the duty of care, requiring of directors the care level that "ordinarily careful and prudent [people] would use in similar circumstances," Graham v. Allis-Chalmers Mfg. Co., 188 A.2d 125, 130 (Del. 1963), dates back to the 1800s. 1 DeNIS J. Block et Al., The Business Judgment Rule: Fiduciary Duties of Corporate Directors 117 (5th ed. 1998).

The duty of loyalty is also a precondition for director independence. Moreover, monetary exposure for breach of the duty of loyalty is a more plausible threat because selfinterested behavior forfeits the protection of the business judgment rule and the exculpatory statutes and may be hard to insure against. Nevertheless, the liability threat associated with the duty of loyalty may offer only limited incentives for director independence because it is not ordinarily triggered by complaisance in the self-interested behavior of others. At least historically, the conflicts that lead to liability are gross, not subtle. In other words, where the director has not personally profited from the action in question, it may be difficult to tag him for the profits wrongfully obtained by others, such as a controlling shareholder. But cf. In re Emerging Commc'ns, Inc., No. Civ.A. 16415, 2004 WL 1305745, at*40 (Del. Ch. May 3, 2004, revised June 4, 2004) (finding that a conflicted director failed to use his financial 
Early in the period, liability for breach of the duty of care uncomplicated by self-dealing was famously described as the "search for a very small number of needles in a very large haystack," 55 and risk of securities fraud liability was non-existent. At the end of the period, Professors Black, Cheffins, and Klausner tell us that liability in duty of care cases is still quite rare and that outside director liability exposure in securities fraud litigation is limited to rare "nearperfect-storm" cases. ${ }^{56}$ Nevertheless the directors' perception of risk seems to have increased over the period, perhaps because of lawyers' exaggerations, ${ }^{57}$ perhaps because of scare-mongering by liability insurers, ${ }^{58}$ or perhaps because of the saliency of outlier cases like Enron and WorldCom, in which outside directors paid out-of-pocket to settle claims. ${ }^{59}$

Indeed, a better (though softer) measure of director apprehension than monetary payouts may be the series of liability insulation mechanisms that were adopted during the period. State corporate indemnification statutes diffused rapidly in the 1950s, and soon covered all negligent behavior. ${ }^{60}$ Director and Officer ("D\&O”) insurance arose in the 1950s and 1960s to cover liability that was not indemnifiable. ${ }^{61}$ Yes, these measures protected directors, but their promotion, which required concerted political activity at the state level, presumably stemmed from growing liability concerns and the risks of liability "loopholes." The most famous liability insulation measure was the

expertise in a going-private transaction that shifted value to controlling shareholder).

55. Joseph W. Bishop, Jr., Sitting Ducks and Decoy Ducks: New Trends in the Indemnification of Corporate Directors and Officers, 77 YALE L.J. 1078, 1099 (1968) (finding four cases); accord Stuart R. Cohn, Demise of the Director's Duty of Care: Judicial Avoidance of Standards and Sanctions Through the Business Judgment Rule, 62 TEX. L. REv. 591, 591 nn.1-2 (1983) (noting only seven successful cases); Henry Ridgely Horsey, The Duty of Care Component of the Delaware Business Judgment Rule, 19 DEL. J. CoRP. L. 971, 982 (1994) (confirming Bishop’s study).

56. Bernard Black et al., Outside Director Liability, 58 STAN. L. REv. 1055, 1061, 1139 (2006). See generally Bernard Black et al., Liability Risk for Outside Directors: A Cross-Border Analysis, 11 European Fin. Mgmt. 153 (2005); Brian R. Cheffins \& Bernard S. Black, Outside Director Liability Across Countries, 84 TEX. L. REV. 1385 (2006). Black et al. found approximately ten post-1980 cases in which outside directors made out-of-pocket payments to settle securities fraud claims. Black et al., Outside Director Liability, supra, at 1070 tbl.2. They argue that appropriate D\&O insurance should eliminate liability even further, leaving open only cases of insolvency and losses beyond D\&O policy limits like Enron (where the directors paid out approximately $\$ 13$ million) and WorldCom (approximately \$25 million). Id. at 1057-62.

57. Bernard Black et al., Outside Director Liability (Before Enron and WorldCom) 51 (Stanford Law \& Econ. Olin Working Paper No. 250, 2003), available at http://ssrn.com/ abstract $=382422$.

58. See Bishop, supra note 55, at 1078.

59. See Joann S. Lublin et al., Directors Are Getting the Jitters-Recent Settlements Tapping Executives' Personal Assets Put Boardrooms on Edge, WALl ST. J., Jan. 13, 2005, at B1.

60. See Model Bus. Corp. Act § 4(o) (1957); Joseph Bishop, LAW of Corporate OFFICERS AND DIRECTORS: INDEMNIFICATION AND INSURANCE § 6.01-.02 (1996).

61. See sources cited supra note 60. 
mid-1980s adoption by Delaware (and then quickly by other states) of director exculpation statutes for breach of the duty of care. ${ }^{62}$ This followed immediately upon the visible ratcheting up of liability standards in Smith v. Van Gorkom. ${ }^{63}$

In the immediate aftermath of the Enron et al. financial scandals, it appeared that state courts, particularly the Delaware courts, might become more receptive to liability theories that would increase a director's monetary exposure for the insiders' wrongful behavior, on the ground of directors' failure to undertake adequate inquiry or oversight. ${ }^{64}$ These new theories of director malfeasance often flew under the banner of "good faith." 65 The speculative flurry was soon put to rest, however. Prolonged litigation over the \$130 million severance paid by the Walt Disney Company to former president Michael Ovitz ended in victory for the directors (but after eight years of litigation), despite behavior that fell far below "best practices."66 In affirming, the Delaware Supreme Court made it clear that "gross negligence (including a failure to inform oneself of available material facts), without more" does not constitute bad faith, ${ }^{67}$ which seemed to require something like scienter, "intentional dereliction of duty, a conscious disregard for one's responsibilities." 68 Subsequently, the Delaware Supreme Court went even further, holding that "bad faith" was not an independent basis for director liability but rather one precipitating condition for liability under the duty of loyalty. ${ }^{69}$ Nevertheless,

62. See DeL. Code ANN. tit. 8, § 102(b)(7) (2001); see also Carl Samuel Bjerre, Note, Evaluating the New Director Exculpation Statutes, 73 CORNELL L. REV 786, 786 (1988).

63. 488 A.2d 858 (Del. 1985). The case was ferociously criticized, see, e.g., Daniel R. Fischel, The Business Judgment Rule and the Trans Union Case, 40 BUs. LAw. 1437, 1455 (1985) (criticizing the majority opinion as "one of the worst decisions in the history of corporate law"), and raised the specter of a D\&O liability insurance crisis, see generally Roberta Romano, Corporate Governance in the Aftermath of the Insurance Crisis, 39 EMORY L.J. 1155 (1990). Romano observes that within two years of Van Gorkom, forty-one states adopted exculpatory statutes. Id. at 1160.

64. Some speculated that Delaware might feel pressure to demonstrate that state corporate law could check managerial wrongdoing to protect its domain against further encroachment by the federal government. See generally William B. Chandler III \& Leo E. Strine, Jr., The New Federalism of the American Corporate Governance System: Preliminary Reflections of Two Residents of One Small State, 152 U. PA. L. REv. 953 (2003).

65. See Hillary A. Sale, Delaware's Good Faith, 89 CoRNELL L. REv. 456 (2004). See generally Melvin A. Eisenberg, The Duty of Good Faith in Corporate Law, 11 DEL. J. CoRP. L. 1, 1 (2006) ("[T]he explicit recognition of the duty of good faith in recent Delaware cases shines a spotlight on that duty and therefore makes it especially important to develop the contours of the duty and to examine the duty from a normative perspective.”).

66. See In re Walt Disney Co., 907 A.2d 693, 697 (Del. Ch. 2005), aff'd, 906 A.2d 27 (Del. 2006).

67. 906 A.2d at 64-65.

68. Id. at 66 .

69. Stone v. Ritter, 911 A.2d 362, 369-70 (Del. 2006). The Stone court also refused to broaden the prior pre-Enron standard of directors' oversight liability, affirming the standard articulated in In re Caremark International Inc., 698 A.2d 959, 971 (Del. Ch. 1996) (opining that "only a sustained or systematic failure of the board to exercise oversight-such as an utter failure to attempt to assure a reasonable information and reporting system exists-will 
the protracted litigation, the courts' willingness to set forth in embarrassing detail the deficiencies of directors' decisionmaking processes, and the implicit threat about liability "next time" may increase directors' vigilance and independence.

Similarly, the potential stick of directors' liability under the federal securities law was muted by institutional realities, yet the fear remained. Even if managers' wrongful conduct could be framed as also constituting a disclosure violation, the applicable liability standard that emerged over the period for directors' liability was a "scienter" test: whether the directors had knowledge of the wrongful disclosure (or were reckless in not knowing). ${ }^{70}$ Moreover, plaintiffs' attorneys in securities class actions have no incentive to prove scienter because this could undercut the $\mathrm{D} \& \mathrm{O}$ insurers' obligation to fund settlements. ${ }^{71}$

Yet for disclosure in connection with a public offering of securities, directors have a "due diligence" obligation to assure the accuracy of the disclosed statements. A recent WorldCom decision on this due diligence obligation means that directors cannot necessarily rely on an auditor's certification where there are "red flags" in the issuer's financials. ${ }^{72}$ Rather than face a trial on what precisely they knew or should have known, and opposed by a public pension fund plaintiff who insisted on personal liability for the directors rather than simply insurance proceeds, the WorldCom independent directors agreed to settle the litigation. Each director's contribution was designed to be approximately $20 \%$ of his or her net worth, approximately $\$ 20$ million in total. ${ }^{73}$ In general, the "shelf-registration" rules that permit immediate issuance of debt and equity securities by large public firms heightened the negligent disclosure liability risk for directors. ${ }^{74}$ Since detailed knowledge about the corporation's financial disclosure enhances the capacity

establish the lack of good faith that is a necessary condition to liability”). See Stone, 911 A.2d at 370 .

70. See Ernst \& Ernst v. Hochfelder, 425 U.S. 185 (1976).

71. See Black et al., Outside Director Liability, supra note 56, at 1103-04.

72. In re WorldCom, Inc., 346 F. Supp. $2 d 628$ (S.D.N.Y. 2004). WorldCom seems to impose greater demands on directors than the previous leading case on director liability for prospectus misstatements, Escott v. BarChris Constr. Corp., 283 F. Supp. 643 (S.D.N.Y. 1968).

73. Gretchen Morgenson, Ex-Directors at WorldCom Settle Anew, N.Y. TiMES, Mar. 19, 2005, at C1.

74. This is mostly because of the time crunch, which deprives underwriters of time to scrutinize the issuer's financial statements before issuing securities. See JoHN C. COFFEE, JR. \& Joel Seligman, Securities Regulation 271-85 (9th ed. 2003) (discussing shelf registration rules and liability risks). Indeed, Bernard Black et al. found that the negligence standard of section 11 was the critical element in most of the identified post-1980 instances of outside director out-of-pocket payments. Black et al., Outside Director Liability, supra note 56, at 1070 tbl.2, 1074 . 
for independent judgment, WorldCom — which creates additional reasons for directors to acquire such knowledge—-should enhance director independence. ${ }^{75}$

\section{b. Rewards (carrots)}

There were a number of innovations during the period aimed at creating incentives for good performance by outside directors. ${ }^{76}$ Circa 1950, director compensation was low and sometimes nonexistent. The tradition, going back to the nineteenth century, was not to pay directors, on the view that the opportunity to monitor management was reward enough for a substantial stockholder. ${ }^{77}$ As it became desirable for firms to put "outsiders" on the board and necessary to compensate them for their time, significant compensation became common; indeed, it became increasingly lavish throughout the period. ${ }^{78}$ Such compensation, of course, can undercut independence if the CEO has influence over director retention.

One 1990s-era governance innovation was to compensate directors in stock (or stock options) to strengthen the alignment of director and shareholder interests. ${ }^{79}$ Despite some evidence that suggests a connection between stockbased director compensation and improved governance, ${ }^{80}$ stock-related

75. For a recent discussion of the post-Disney, post-WorldCom environment for directors, see Symposium, Director Liability, 31 DEL. J. CoRP. L. 1011 (2006).

76. See generally David Yermack, Remuneration, Retention, and Reputation Incentives for Outside Directors, 59 J. FIN. 2281 (2004) (investigating the incentives received by outside directors of Fortune 500 firms from 1994 to 1996).

77. Charles M. Elson, Director Compensation and the Management-Captured BoardThe History of a Symptom and a Cure, 50 SMU L. REV. 127, 135-36 (1996). Indeed, director compensation was not legally recognized in the United States until the late 1940s, although informal modes flourished, such as meeting fees, passing of stock tips, and even salaries. Id. at 138,142 . As of 1979 , the median NYSE firm paid an annual director retainer of less than $\$ 10,000$. SEC STAFF REPORT, supra note 11, at 605 tbl.9.

78. Elson, supra note 77 , at 147-56.

79. See Eliezer M. Fich \& Anil Shivdasani, The Impact of Stock-Option Compensation for Outside Directors on Firm Value, 78 J. Bus. 2229, 2229 (2005) (noting that the number of Fortune 1000 firms using stock-based remuneration increased from just over 200 in 1992 to almost 500 in 1995).

80. Fich and Shivdasani report that the presence of outside director stock-option plans is associated with economically significantly higher market-to-book ratios, a greater fraction of independent directors on the board, higher institutional investor ownership, and stock price effects that suggest that investors believe that such plans improve monitoring. See id. at 2230-31. Some studies have associated significant stock ownership with increased firm value, see Randall Morck et al., Management Ownership and Market Valuation: An Empirical Analysis, 20 J. Fin. ECON. 293 (1988) (using Tobin's $q$ as the measure of value), and with lower executive compensation and better connection to pay for performance, see Tod Perry, Incentive Compensation for Outside Directors and CEO Turnover (July 1999) (unpublished manuscript), available at http://papers.ssrn.com/abstract=236033. Moreover, courts came to give greater deference to target board defensive measures where the outside directors were substantial stockholders, most notably in Unitrin, Inc. v. American General Corp., 651 A.2d 1361 (Del. 1995). 
compensation was hardly a panacea. Few directors actually acquired a great enough equity interest to generate a strong incentive effect (assuming that incentives are increasing in ownership levels). Directors typically obtained their equity stake through annual stock-based compensation rather than an initial grant of stock options or restricted stock. Over time the stake accumulates, but this also undercuts director independence where the CEO has influence over director retention.

More seriously, perhaps, stock-based compensation may create a distinctive set of perverse incentives for the directors, as demonstrated by the wave of financial disclosure problems in the late 1990s and early 2000s. The director receiving stock-based compensation, like the similarly compensated CEO, may be tempted to accept aggressive accounting rather than stock-pricepuncturing disclosure. ${ }^{81}$ It is important to remember that with respect to disclosure obligations, the public board has a dual duty—not only to the firm's shareholders, but to capital market participants more generally. This is because of the positive (negative) externalities associated with accurate (misleading) disclosure. ${ }^{82}$ With such divided duties, it's hard to know which way to set the optimal stock-based incentive effects. ${ }^{83}$

\section{c. Reputation}

Reputation provides another sort of stick or carrot that could enhance director independence. Presumably directors would not want to be associated with a poorly performing firm or a firm that is stigmatized because of a business scandal, and instead would want to be associated with a bellwether firm. But the incentive effects of reputation consist not merely in the director's subjective distaste for embarrassment and his preference for respect, but also in the business opportunities, including other directorships, that are affected by reputation. ${ }^{84}$ The effectiveness of reputation-based incentives is limited by the noisiness of reputation markets. Plainly a director suffers a reputational

81. For example, there is some evidence that outside directors participated along with managers in taking backdated stock options. See Lucian Arye Bebchuk et al., Lucky Directors (John M. Olin Ctr. for Law, Econ. \& Bus., Harvard Law Sch., Discussion Paper No. 573, 2006), available at http://ssrn.com/abstract=952239.

82. See Jeffrey N. Gordon, Governance Failures of the Enron Board and the New Information Order of Sarbanes-Oxley, 35 ConN. L. REV. 1125 (2003).

83. See Jeffrey N. Gordon, What Enron Means for the Management and Control of the Modern Business Corporation: Some Initial Reflections, 69 U. CHI. L. REV. 1233 (2002) (arguing that audit committee members should receive no stock-based compensation).

84. See, e.g., Stuart C. Gilson, Bankruptcy, Boards, Banks, and Blockholders: Evidence on Changes in Corporate Ownership and Control When Firms Default, 27 J. Fin. ECON. 355 (1990) (finding that directors of firms that go bankrupt subsequently serve on fewer boards); Yermack, supra note 76 (2004) (finding that association with highperforming firms leads to new board seats and reputation provides half of directors' total incentives). See generally Black et al., supra note 57. 
sanction if there is a financial catastrophe or major legal problem at the firm. In the more typical case of firm underperformance or a minor legal problem, however, there may be little or no reputational effect. ${ }^{85}$

In general, reputation markets became more effective over the period, particularly beginning in the 1980s. The salience of hostile takeovers drew media attention-newspapers, books, magazines, and movies-not simply to the actors in a particular case but to governance activity more generally. ${ }^{86}$ High-stakes transactions gave rise to high-stakes litigation, which often was closely followed by the business press. Delaware courts issued opinions that publicly evaluated the behavior of directors as well as other corporate actors, often in harsh terms. ${ }^{87}$ Indeed, in light of the Delaware courts' reluctance to impose monetary liability on directors, the most significant independenceenhancing effect of litigation is probably through improving the operation of the reputation market rather than through the threat of monetary sanctions. ${ }^{88}$

Reputation markets also became more effective because of the activity of activist institutional investors. For example, beginning in the 1990s CalPERS publicly targeted firms (and their boards) for poor performance and for noncompliance with its corporate governance code. $^{89}$ Other activist

85. First, a relatively routine problem will not attract sufficient media attention to achieve the salience necessary to attach the director to the matter. Second, it is generally hard to make judgments about director responsibility when a firm underperforms. In the egregious cases, Enron or WorldCom for example, particularized judgments seem hardly necessary since surely someone on the board should have been sounding an alarm. No longtime director's reputation emerged unscathed. In the more typical case, the competence of director monitoring rarely seems relevant.

86. See generally Alexander Dyck \& Luigi Zingales, The Corporate Governance Role of the Media (Ctr. for Research in Sec. Prices, Working Paper No. 543, 2002), available at http://ssrn.com/abstract=335602.

87. See, e.g., Paramount Commc’ns Inc. v. QVC Network Inc., 637 A.2d 34 (Del. 1994); Mills Acquisition Co. v. MacMillan, Inc., 559 A.2d 1261 (Del. 1989); In re Walt Disney Co., 907 A.2d 693 (Del. Ch. 2005). See generally Edward B. Rock, Saints and Sinners: How Does Delaware Corporate Law Work?, 44 UCLA L. REV. 1009, 1103-04 (1997); David A. Skeel, Jr., Shaming in Corporate Law, 149 U. PA. L. REV. 1811 (2001).

88. Thus the greatest importance of Disney may be the scope of director decisions potentially subject to detailed public scrutiny. Previously high-profile litigation arose in hostile takeovers or management buyouts. But Disney signals that the Delaware courts may be willing to scrutinize director actions in important but not bet-the-company matters, particularly where management interests may clash with shareholder interests (like executive compensation). This will improve the effectiveness of the reputational sanction and thus strengthen director independence.

89. In 1990, for example, CalPERS and the New York State and Local Retirement System published a letter to the GM board that attacked the board and that spurred governance reform. Letters to GM Directors Trigger Pension Fund Uproar, CoRP. GovernANCE Bull. (Investor Responsibility Research Ctr., Gaithersburg, Md.), Jan.-Feb. 1990, at 18. More generally, see, for example, Calpers, Politicians Respond to Corporate Downsizing, CORP. GOVERnANCE Bull. (Investor Responsibility Research Ctr., Gaithersburg, Md.), Apr.-June 1996, at 11. CalPERS began filing corporate governance proposals in 1986. In 1991, Shareholders Will Cast Sharp Eye on Boards of Directors, CORP. GOVERnANCE Bull. (Investor Responsibility Research Ctr., Gaithersburg, Md.), 
shareholders also began to use press campaigns to promote change. ${ }^{90}$ A 1993 article by Professor Joseph Grundfest unleashed what became the institutional investor's reputational strategy of choice: a "just vote no" campaign against directors as a group or individually. ${ }^{91}$ A full-blown proxy campaign to replace the board or particular directors was not attractive to the institutions because of familiar collective action problems. Yet they could "just vote no" against management's candidates, and publicize their reasons for doing so. ${ }^{92}$ The potential embarrassment factor of being a targeted director heightened the potency of reputation markets.

\section{Intra-board structures and functions}

Another important mechanism for director independence is the creative use of board structure to create a spirit of teamwork and mutual accountability among independent directors that helps foster independence-in-fact. Structural innovations multiplied over the period, including: board committees tasked with specific functions, "special committees" for specific legal or transactional issues, and various institutions to restrain the CEO's agenda-setting authority, such as the "lead director" and the "executive session."

\section{a. Board committees}

One particularly important innovation was the board committee assigned a specific key function. Beginning in the 1970s, "best practice” pronouncements called for three specific committees: the audit committee, the compensation committee, and the nominating committee, each with a majority of independent directors. ${ }^{93}$ Each committee is functionally tasked in areas where the interests of managers and the shareholders may conflict. Independence-in-fact may be enhanced in two respects. First, the ownership and accountability for a specific critical task may lead to greater autonomy from the CEO in performing that

Sept.-Oct. 1990, at 3.

90. In 1992, for example, activist shareholder Robert Monks publicly shamed the Sears-Roebuck board into accepting proposed reforms through disparaging advertisements in the Wall Street Journal. Dyck \& Zingales, supra note 86, at 2.

91. Joseph A. Grundfest, Just Vote No: A Minimalist Strategy for Dealing with Barbarians Inside the Gates, 45 StAN. L. REV. 857 (1993).

92. This strategy was facilitated by the SEC's 1992 amendment of the proxy rules that loosened some constraints on coordinated institutional action. See Regulation of Communications Among Shareholders, Exchange Act Release No. 31,326, Investment Company Act Release No. 19,031, 52 SEC Docket 2028 (Oct. 16, 1992). The rules permitted institutions to engage in "conscious parallelism" without triggering proxy filing requirements. Such "non-concerted" behavior does not trigger filing obligations as a "group" under section 13(d) of the 1934 Act.

93. See, e.g., ABA Comm. on Corporate Laws, supra note 31; Bus. Roundtable, Statement, The Role and Composition of the Board of Directors of the Large Publicly Owned Corporation, 33 Bus. LAW. 2083, 2108-10 (1978). 
task. Second, the practice of acting jointly and autonomously in a targeted area may carry over to other important roles of the board, such as evaluating managerial performance and strategy. The potential for enhanced independence from this structural/functional mechanism source grew gradually over the period, beginning in the 1970s. One limiting factor was that only at the end of the period, via a NYSE rule, were these committees necessarily staffed solely by independent directors. ${ }^{94}$

The most important board committee was the audit committee, a major objective of corporate governance reformers. Although calls for the creation of an audit committee began as early as $1939,{ }^{95}$ critical mass did not coalesce until the 1970s. ${ }^{96}$ In 1974, the SEC began requiring disclosure of the existence of an audit committee (or lack thereof), ${ }^{97}$ and in 1978 the SEC published general guidelines for what an audit committee should do. ${ }^{98}$ The NYSE began requiring audit committees in $1977 .{ }^{99}$ Indeed, by 1979, virtually all NYSElisted companies had audit committees, and for $92 \%$ of the firms, the members were non-management directors. ${ }^{100}$ By the end of the 1980s, the NASDAQ and the Amex introduced audit committee requirements as well. ${ }^{101}$ Current

94. See NYSE, Inc., Listed Company Manual §§ 303, 303A (2007); text accompanying notes 36-37. It should also be noted that the Enron audit committee was staffed solely by independents, and that the structural innovation of the compensation committee coincided with the controversial run up in executive compensation.

95. The NYSE made such a suggestion in 1939. Edward F. Greene \& Bernard B. Falk, The Audit Committee-A Measured Contribution to Corporate Governance: A Realistic Appraisal of Its Objectives and Functions, 34 Bus. LAW. 1229, 1233 n.16 (1979) (citing Report of Subcommittee on Independent Audit and Audit Procedure of NYSE Commission on Stock List 7 (1939)). The SEC made an audit committee proposal in 1940. In re McKesson \& Robbins, Inc., Exchange Act Release No. 2707, [1940 Transfer Binder] Fed. Sec. L. Rep. (CCH) ๆ 72,020 (Dec. 5, 1940).

96. The American Institute of Certified Public Accountants advocated the use of audit committees in 1967; the leading accounting firm, Arthur Anderson \& Co., signed on in 1972. See Greene \& Falk, supra note 95, at 1233 \& n.16, 1234. An important congressional committee picked up the theme in 1976. See SubCOMM. ON OvERSIGHT \& INVESTIGATIONS OF THE H. COMm. ON INTERSTATE AND Foreign COMMERCE, 94TH CONG., RePORT ON FEDERAL Regulation AND Regulatory ReForm 29-42 (Subcomm. Print 1976).

97. Item 8(e), Schedule 14A, 17 C.F.R. § 240.14a-101 (1978).

98. Proposed Rules Relating to Shareholder Communications, Shareholder Participation in the Corporate Electoral Process and Corporate Governance Generally, Exchange Act Release No. 14,970, 15 SEC Docket 291 (July 18, 1978).

99. See supra note 36 and accompanying text.

100. ALI PRINCIPLES, supra note 46, § 3.05 n.4 (citing a 1979 study of the American Society of Corporate Secretaries). On the other hand, apparently one-third of audit committee members were "affiliated" directors, and affiliated directors constituted the majority of the audit committee for nearly a quarter of firms. See David Vicknair et al., A Note on Audit Committee Independence: Evidence from the NYSE on "Grey" Area Directors, 7 AcCT. HoRIzOns 53, 55, 56 (1993) (using a sample of 100 NYSE firms in the 1980s). This was permitted until the 1999 amendment of the NYSE listing standard. See supra text accompanying note 37.

101. The ASE "recommended" audit committees to its listed companies in 1980 and made them mandatory in 1991. Douglas C. Michael, Untenable Status of Corporate 
standards, through both exchange listing rules and Sarbanes-Oxley, mandate audit committees for every publicly owned company, as well as stringent standards of independence and financial expertise. ${ }^{102}$

Instituting the compensation committee came somewhat later than the audit committee. For example, the SEC began to require disclosure of whether a firm had a compensation committee and the committee's composition only in 1992. ${ }^{103}$ Throughout much of the period, it was common for management directors to sit on the compensation committee, although outsiders were typically the majority. ${ }^{104}$ Nominating committees (separately discussed below) also became more prevalent during the period, ${ }^{105}$ in response to pressure from institutional investors. ${ }^{106}$ Compensation and nominating committees, both staffed by independent directors, are now required by the NYSE listing standard. ${ }^{107}$

At best, functionally tasked board committees should enhance independence, particularly in regard to the targeted task. Actual practices, until the post-Enron reform wave, made the committees less effective in that regard. For the audit committee, management hired (and fired) the auditor and also determined the level of more lucrative non-auditing consulting work assigned to the auditor, undercutting the auditor's allegiance to the audit committee. This managerial power over the auditor relationship was, of course, known to the audit committee members and would have dampened their independent engagement with significant auditing issues. Sarbanes-Oxley, passed in 2002, now gives the audit committee power (and responsibility) over the firm's

Governance Listing Standards Under the Securities Exchange Act, 47 Bus. LAW 1461, 1474 (1992). The NASDAQ required its listed companies to have independent audit committees in 1987. Id. at 1475 .

102. See sources cited supra note 53; see also Bus. Roundtable, Principles of CORPORATE GOVERNANCE 16 (2002), available at http://www.businessroundtable.org/pdf/ 704.pdf.

103. See Executive Compensation Disclosure, Securities Act Release No. 6962, Exch. Act Release No. 31,327, Investment Company Act Release No. 19,032, 52 SEC Docket 1961 (Oct. 16, 1992) (currently reflected in Regulation S-K Item 402(j)). The proposed release had much more stringent disclosure standards for ties and interests that might undercut independence, including non-profit organization director interlocks. Compare Securities Act Release No. 6940, Exchange Act Release No. 30,851, 57 Fed. Reg. 29,583, at 29,596 (proposed July 2, 1992), with Securities Act Release No. 6962, Exchange Act Release No. 31,327, Investment Company Act Release No. 19,032, 57 Fed. Reg. 48,126, at 48,142-43 (adopted Oct. 21, 1992).

104. See ALI PRinciples, supra note 46, § 3A.05 n.1.

105. A $1992 \mathrm{Korn} /$ Ferry study showed that, of the companies studied, $98 \%$ had audit committees, 95\% had compensation committees, and 67\% had nominating committees. Korn/FerRy InT'L, BoARD OF Directors Nineteenth ANNUAL StUdy 9 (1992). By 1995, those percentages had increased to $100 \%, 99 \%$, and $71 \%$, respectively. KORN/FERRY INT'L, TWENTY-SEVENTH ANNUAl BoARD OF DiRectors STUdy 13 (2000).

106. Gregory V. Varallo \& Daniel A. Dreisbach, Fundamentals of Corporate GOVERnANCE: A Guide FOR DiRECTORS AND CORPORATE COUNSEL 24 (1996).

107. NYSE, Inc., Listed Company Manual § 303A.04-.05 (2007). 
auditor relationships and audit policies. ${ }^{108}$ This, in turn, should make the audit committee a stronger source of director independence.

The compensation committee also has a similar story of dampened independence. In setting executive pay, compensation committees typically have relied on the compensation consultant who also provided firm-wide compensation and human resources guidance. Such a management-retained consultant, earning the largest portion of its fees from the firm-wide assignment, is unlikely to make recommendations or offer viewpoints that senior management would find distressing. Reliance on such a consultant will inevitably dampen the committee's independence. ${ }^{109}$

\section{b. The "special committee"}

The model for the maximally independent board committee is the "special committee" that a company sets up in cases where the interests of senior management seem to most directly conflict with the corporation's. This structural innovation came into widespread use beginning in the 1970s, but only in a limited set of circumstances. ${ }^{110}$ One case was a control transaction, such as a management buyout, in which management is part of a group that

108. Section 301 of the Sarbanes-Oxley Act of 2002 makes the audit committee "directly responsible for the appointment, compensation, and oversight of the work" of the firm's auditor. Sarbanes-Oxley Act of $2002 \S 301,15$ U.S.C. § 78j-1(m)(2) (2007). Section 202 of Sarbanes-Oxley provides that "[a]ll auditing services ... provided to an issuer by the auditor of the issuer shall be preapproved by the audit committee of the issuer." Id. § 78j1(i)(1)(A). Section 201 of Sarbanes-Oxley prohibits the provision of certain non-audit services by the firm's auditor, id. $\S 78 \mathrm{j}-1(\mathrm{~g})$, and required preapproval of the audit committee for non-prohibited services, id. § 78j-1(h). See Strengthening Requirements Regarding Auditor Independence, Securities Act Release No. 8183, Exchange Act Release No. 47,265, Public Utility Holding Company Act Release No. 27,642, Investment Company Act Release No. 25,915, Investment Advisers Act Release No. 2103, 68 Fed. Reg. 6006 (Feb. 5, 2003).

109. See Lucian Bebchuk \& Jesse Fried, Pay Without Performance: The Unfulfilled PRomise of EXeCUTIVe COMPENSATION 37-39 (2004). As part of a new initiative on executive compensation disclosure, the SEC now requires more stringent disclosure of relationships that potentially undercut the independence of the compensation committee members (and other directors) and disclosure of whether the committee itself retains any compensation consultant. The Commission does not require disclosure of the consultant's other possible economic relationships with the corporation. See Executive Compensation and Related Person Disclosure, Securities Act Release No. 8732A, Exchange Act Release No. 54,302A, Investment Company Act Release No. 27,444A, 71 Fed. Reg. 53,158, at 53,205 (Sept. 8, 2006) (discussing compensation committee disclosure as required in new Item 407(e) to Regulation S-K). In the 2007 proxy season, shareholder activists began to press for the disclosure of such potential conflicts for compensation consultants.

110. See generally Scott V. Simpson, The Emerging Role of the Special CommitteeEnsuring Business Judgment Rule Protection in the Context of Management Leveraged Buyouts and Other Corporate Transactions Involving Conflicts of Interest, 43 Bus. LAW. 665 (1988). 
seeks to buy out the public shareholders; ${ }^{111}$ or a parent-subsidiary merger, in which it is assumed that the target management's allegiance is likely to be towards the controlling shareholder who appointed them. ${ }^{112}$ Another case was a shareholder derivative suit, in which officers and directors allegedly violated a fiduciary duty to the corporation. ${ }^{113}$ In these cases the nominal independence of the committee was buttressed by the committee's hiring of independent advisors, particularly independent legal counsel. Such independent advisors, whose allegiance was not to management, could drive the process and promote the directors' sense of independence. However, "special committees" had little pervasive effect on board practice. Most often, they were convened in "final period" situations, after which the entity disappeared. Moreover, the potency of a committee's (or the board's) retaining its own advisors was well understood by corporate management and thus strongly resisted. ${ }^{114}$ The lesson learned from special committees underpins the Sarbanes-Oxley decision to give the audit committee authority over the auditor's employment (and to give the audit committee the power to hire its own counsel and other advisors). ${ }^{115}$

\section{c. Executive session; "lead director”}

Another notable structural element was the emerging practice of the board's meeting in executive session (meaning, without senior management present) under the guidance of a "lead director," as part of each regularly scheduled board meeting. An executive session gives the board the opportunity for candid discussion free of senior management's possibly inhibitory presence. Holding executive sessions became regular practice in the 1990s. ${ }^{116}$ The 1996 Korn/Ferry study indicated that the boards of $62 \%$ of respondents met in executive session during that year. ${ }^{117}$ General Motors' 1994 Corporate Governance Guidelines, a bellwether in U.S. corporate governance development, established executive sessions to be held at least three times per

111. See generally William T. Allen, Independent Directors in MBO Transactions: Are They Fact or Fantasy?, 45 Bus. Law. 2055 (1990).

112. See Weinberger v. UOP, Inc., 457 A.2d 701, 709 n.7 (Del. 1983).

113. E.g., Zapata Corp. v. Maldonado, 430 A.2d 779 (Del. 1981).

114. See, e.g., ALI PRINCIPLEs, supra note 46, § $3.04 \mathrm{cmt}$. c (imposing full-board or judicial approval requirements for such retentions).

115. See Sarbanes-Oxley Act of $2002 \S 301,15$ U.S.C. § 78j-1(m)(5)-(6) (2007). Similarly, NASDAQ has adopted a requirement that related party transactions be approved by the audit committee or another committee consisting solely of independent directors. NASDAQ, Inc., Marketplace Rules R. 4350(h) (2007).

116. See Working Group on Corporate Governance, A New Compact for Owners and Directors, HARV. Bus. REV., July-Aug. 1991, at 141, 142 (suggesting outside directors meet in executive sessions "no less than once a year").

117. Korn/FERry InT’L, 24TH ANNUAl BoARd of Directors Study 21 (1996). Interestingly, however, this percentage dropped to $60 \%$ by 2000 . KORN/FERRY INT'L, 27TH ANNUAl BOARD OF DiRECTORS STUDY 13 (2000). 
year. ${ }^{118}$ "Regularly scheduled executive sessions" are now required by the NYSE listing requirements. ${ }^{119}$ Because institutionalized, such a meeting does not require special director initiation that might well be regarded by senior management as a hostile act.

The naming of a "lead director"-an independent director who convenes the board, where the chair is a senior executive, typically the CEO-was itself a structural innovation. It represented a compromise between those who, following the U.K. model, wanted to separate the roles of chair and CEO by making a non-executive director the chair, and those who felt that such separation would undermine the CEO's authority. ${ }^{120}$ Following the 1992 release of the Cadbury Report in the United Kingdom, ${ }^{121}$ calls for lead directors became more pronounced. ${ }^{122}$ Lead directors came to play an increasingly important role in U.S. corporate governance practice, ${ }^{123}$ providing an organizational focal point for crises where the CEO's actions have been challenged. ${ }^{124}$

118. Gen. Motors BD. OF Dirs., Corporate GovernanCE Guidelines 7 (1994).

119. NYSE, Inc., Listed Company Manual § 303A.03 (2007). See Working Group on Corporate Governance, supra note 116.

120. Two leading corporate reform groups, the Council of Institutional Investors and Institutional Shareholder Services, argue for separation of roles. Apparently such separation is relatively common among all public companies-approximately $50 \%$, according to the National Association of Corporate Directors-but still uncommon among the largest firmsonly $14 \%$ of the top 100 , according to a Shearman \& Sterling report. See Ann Therese Palmer, Should the Top Roles Be Split?, Chief Executive, May 2005, at 16, 16.

121. Cadbury Comm., The Financial Aspects of Corporate Governance 58 (1992) ("Where the chairman is also the chief executive, it is essential that there should be a strong and independent element on the board, with a recognized senior member.").

122. See, e.g., Lipton \& Lorsch, supra note 21, at 70.

123. The fraction of Business Roundtable firms with an independent chairman, lead director, or presiding director increased from approximately 25\% in 2002 to $55 \%$ in 2003, to $71 \%$ in 2004 , to $83 \%$ in 2005 , and to $91 \%$ in 2006. See Bus. RoundtaBle, supra note 20; Press Release, Bus. Roundtable, New Business Roundtable CEO Survey Shows Continuing Improvements in Corporate Governance Practices (Mar. 9, 2004), available at http://www.businessroundtable.org/newsroom/document.aspx?qs=5626BF807822B0F13D 3429167F75A70478252; Press Release, Bus. Roundtable, The Business Roundtable Releases Corporate Governance Survey (July 15, 2003), available at http://www.businessroundtable.org/newsroom/document.aspx?qs=55B6BF807822B0F1DD6 449167F75A70478252.

124. Take two examples from 2005 and 2006: First, as the investigation of AIG Corp. began to reveal evidence of senior management's involvement in transactions that produced questionable accounting results, the lead director steered the board towards the ouster of the incumbent chair and CEO and the selection of a new CEO. Second, in the face of widespread dissatisfaction within Morgan Stanley and its shareholder base with the strategy and leadership of the chairman and CEO, the lead director eventually promoted the resignation of the incumbent and his replacement with a former senior executive.

The NYSE listing standards require that a company specify in its proxy statement the name or method of selection of the "presiding director" for executive sessions. NYSE, Inc., Listed Company Manual $\S$ 303A.03 (2007). In many cases the role of "lead director" is played by the chair of the nominating/corporate governance committee. See SHEARMAn \& 


\section{Reducing CEO influence in director selection and retention}

A director's independence-in-fact may be seriously affected by the route by which the director arrived on the board-the director's "genealogy." Until recently, CEOs heavily influenced-if not controlled outright-director selection. ${ }^{125}$ Directors picked in this way are likely to feel a strong sense of loyalty, even gratitude, to the CEO. ${ }^{126}$ Moreover, as CEO-influenced director selection also implies some CEO role in the director retention decision, a director whose "independence" aggravates the CEO may find himself politely invited not to stand for reelection. ${ }^{127}$ Throughout almost the entire period from the 1950s to the 2000s, CEOs successfully resisted reforms that would have increased shareholder influence in director selection, including the SEC's 2003 shareholder ballot access proposal. On the other hand, the increasing use of nominating committees later in the period, and the growing practice of staffing the nominating committee solely with independent directors, did reduce CEO influence to some extent.

CEOs won a number of battles in the period over the practical scope of the shareholders' nominal right to present director nominees at the annual meeting. The most important barrier facing dissidents is the expense, including the compliance costs of the SEC's proxy rules and the printing, mailing, and publicity costs of waging an election contest in a diffusely owned firm. ${ }^{128}$ The

STERLING LLP, supra note 20, at 5.

125. See, e.g., LORSCH WITH MACIVER, supra note 23, at 20-23 (arguing that even with the advent of nominating committees, CEOs still have a strong hand in the selection process); MACE, supra note 22, at 94-101 (arguing that CEOs pick directors).

126. See, e.g., James Wade et al., Golden Parachutes: CEOs and the Exercise of Social Influence, 35 ADmin. ScI. Q. 587 (1990) (finding that directors elected during the CEO's tenure may feel obligation and loyalty); James D. Westphal \& Edward J. Zajac, Who Shall Govern? CEO/Board Power, Demographic Similarity, and New Director Selection, 40 Admin. ScI. Q. 60 (1995) (finding that CEO influence in director selection leads to demographically similar directors sympathetic to the CEO); see also Anil Shivdasani \& David Yermack, CEO Involvement in the Selection of New Board Members: An Empirical Analysis, 54 J. FIN. 1829 (1999) (finding that boards with CEO involvement in director selection have a higher fraction of pick-affiliated ("grey”) directors than of true independents and finding a recent trend away from CEO involvement); Edward J. Zajac \& James D. Westphal, Accounting for the Explanations of CEO Compensation: Substance and Symbolism, 40 ADMIN. SCI. Q. 283 (1995).

127. An interesting variation on the $\mathrm{CEO} /$ board selection question arises when the board recruits the CEO. (An inside CEO successor probably has been groomed, if not directly chosen, by the outgoing CEO and may inherit, instead of independently generating, the board's support.) A board that has recruited the CEO presumably will be more independent, particularly when the CEO is an outsider. Common lore is that one of the missions of a new CEO is to stock the board with his loyalists.

128. The cost of waging a proxy contest is also affected by the fraction of institutional ownership; concentrated ownership reduces the costs of solicitation. In January 2007, the SEC adopted a rule that would allow an insurgent to post proxy materials on the Internet rather than to print and mail the materials (though it must provide a paper copy to a requesting shareholder). See Internet Availability of Proxy Materials, Exchange Act Release 
campaign finance rules that emerged in the 1950s strongly favor the managerial incumbents: the dissidents must fund their campaign from their own pockets; the incumbents have virtually unlimited access to the corporate treasury. As a practical matter, the dissidents are reimbursed only if they successfully obtain control of the board. ${ }^{129}$ Subsequent proposals for qualified reimbursement-for example, tied to the dissident's fraction of the votes received-have gone nowhere.

The obvious low cost alternative to a separate proxy contest would be to grant shareholders access to the management proxy to present director candidates. However, CEOs won a victory from the SEC in the 1950s and again in the 2000s that have kept shareholders from accessing the management proxy. In fashioning its shareholder proposal rule in the 1950s following a series of high profile proxy contests, the SEC gave the issuer the right to exclude a proposal "that relates to an election for membership on the company's board of directors" from the management proxy. ${ }^{130}$ As a result, instead of piggy-backing on the management proxy, a dissident needs to wage an independent proxy contest. Five decades later, in 2003 the Business Roundtable successfully fended off the SEC's proposed "security holder nomination" rule, which would have provided dissidents with access to the management proxy in specified circumstances. ${ }^{131}$ Similarly, CEOs prevailed in a campaign to unwind cumulative voting, a historically important mechanism

No. 55,146, Investment Company Act Release No. 27,671, 72 Fed. Reg. 4148 (Jan. 29, 2007). This will significantly reduce an insurgent's costs.

129. Rosenfeld v. Fairchild Engine \& Airplane Corp., 128 N.E.2d 291 (N.Y. 1955). The consequence is that insurgent efforts will be undersupplied because insurgents are likely to bear the full cost of the election contests while at best receiving only the gains proportional to their ownership stake. Such a reimbursement rule creates a particular barrier to electoral success. Shareholders who might be persuaded to add one or two dissident directors will be very leery about a shift in control through an election contest to insurgents who, by hypothesis, are unwilling to pay a control premium. Yet if the insurgents run and win with a "short slate" that substitutes one or two dissident directors for management's nominees, the new board — on which the dissidents are an unwelcome minority —is unlikely to reimburse the insurgents despite their electoral success.

130. Securities Exchange Act of 1934 Rule 14a-8(i)(8), 17 C.F.R. § 240.14a-8(i)(8) (2007). See generally Jeffrey N. Gordon, Institutions as Relational Investors: A New Look at Cumulative Voting, 94 Colum. L. Rev. 124, 152-54 (1994) (describing how an increased number of high profile proxy contests in the 1950s led to Congressional and SEC hearings and fanned general alarm about the potential power of shareholder dissidents). A recent Second Circuit case has apparently opened the door to shareholder-proposed bylaws that would mandate access to the management proxy for shareholder nominees. See Am. Fed'n of State, County \& Mun. Employees v. Am. Int’l Group Inc., 462 F.3d 121 (2d Cir. 2006).

131. See Security Holder Director Nominations, Exchange Act Release No. 48,626, Investment Company Act Release No. 26,206, 68 Fed. Reg. 60,784 (proposed Oct. 23, 2003). For a discussion of the Business Roundtable lobbying efforts, see Lucian Arye Bebchuk, The Case for Shareholder Access: A Response to the Business Roundtable, 55 CASE W. RES. L. REV. 557 (2005). 
that uses proportional representation in a way that facilitates shareholder access to the board. ${ }^{132}$

One piece of the reform agenda did prevail: the creation of a nominating committee with responsibility for vetting and selecting director candidates. In 1979 , only $19 \%$ of the companies sampled in a SEC study had nominating committees; by 1981, a subsequent SEC study showed an increase to $30 \%$; in 1989, a Korn/Ferry study reported that $57 \%$ of the responding firms had a nominating committee. ${ }^{133}$ As of 1992 when ALI published Principles of Corporate Governance, "best practice" called for a nominating committee that had no officer members but could have affiliated directors as members. ${ }^{134}$ As per the 2003 revision of the NYSE listings standards, NYSE-listed companies were required to have a nominating committee consisting solely of "independent" directors, under a standard that would exclude most affiliated directors as well as officers. ${ }^{135}$

The usefulness of a nominating committee in promoting independence-infact of directors is not altogether clear. ${ }^{136}$ On the one hand, the ALI project made it clear that a CEO "can be expected to be highly active" in recommending and discussing candidates with the committee and in recruiting candidates for the board. ${ }^{137}$ The CEO often will select the executive search firm that the committee uses to look for director candidates. On the other hand, the nominating committee process might shield a director who has begun to challenge the CEO from retaliation. Extensive new SEC rules adopted in 2004

132. See Gordon, supra note 130. Cumulative voting operates in two distinct settings. First, a single shareholder (or cohesive group) owning a significant minority block can automatically elect a director to the board. But second, cumulative voting lowers the cost of mobilizing diffuse shareholders because electoral success-in the sense of placing a nominee on the board-requires much less than $50 \%$ of the votes. For example, for a tenperson board elected annually, a dissident need to rally only a $10 \%$ shareholder vote to put a director on the board. So cumulative voting offers significant potential for shareholder selection of at least some directors who would be independent in this genealogical sense. Alarmed by the role that cumulative voting played in some prominent proxy contests of the 1950s, CEOs and their allies went to work. The hostile takeovers of the 1980s brought a further wave of managerial efforts to eliminate cumulative voting as a route to board representation. Circa 1950, twenty-two states had mandatory cumulative voting; circa 1990, only six did. Id. at 142-46, 148-54.

133. See ALI PRINCIPLES, supra note 46, § 3A.04 reporter’s n.1.

134. Id. § 3A.04.

135. See NYSE, Inc., Listed Company Manual §§ 303, 303A (2007). NASDAQ’s rules, which are geared to the size diversity of NASDAQ-listed companies, require either a nominating committee or a practice under which nominations are made by the independent directors of the board.

136. See, e.g., MACE, supra note 22, at 95 (quoting a CEO who stated, "Once I have decided on the man who should be our new board member, I discuss this informally outside of board meetings with our three-man committee of the board that officially nominates people to the board"). Writing in 1989, LORSCH WITH MACIVER, supra note 23, at 20, found that $55 \%$ of the directors they surveyed said that the CEO was heavily involved in the identification of possible candidates.

137. ALI PRINCIPLES, supra note 46, § 3 A.04 cmt. c. 
require disclosure of nominating committee practices, particularly the attributes the committee regards as essential and the committee's search and evaluation process, including the process for vetting director candidates suggested by shareholders. ${ }^{138}$ The goal, presumably, is to force the nominating committee to set forth the standards that guide its work so as to provide a basis for ex post scrutiny. Moreover, involvement by the CEO presumably would be a point for disclosure and that alone may tamp down the CEO's influence.

In measuring the effect of a nominating committee, the different conceptions of "independence" are important. By the end of the period, CEOs came to accept a nominating committee composed of "independent" directors, if only because the directors' views of the firm were likely to be have been shaped by the CEO's vision. However, CEOs continued to fight tooth and nail against measures that would increase direct shareholder access to the board. From the CEO's perspective, the shareholder-nominee director was not independent, but rather dependent on the proposing shareholder group and its particularistic agenda. ${ }^{139}$ On this view, nominating committees produce directors independent of both shareholders and the CEO.

\section{Summary of Part I.B}

This nonexhaustive survey of the mechanisms of director independence shows that reform efforts over the 1950-2005 period did, on balance, enhance substantially the conditions that foster director independence. The relationship rules created obvious protections, and the structural innovations within the board have been promising. Putting aside the independent nominating committee, which will have some pro-independence effect, other efforts to strengthen the shareholder hand in director selection did not succeed. However, it is reasonable to conclude that the cumulative effect of innovations in these various mechanisms significantly increased director independence over the period. But the difficult problem remains: independence is more a disposition, a state of mind, rather than a concrete fact. What might have been more significant than the mechanisms themselves was the constant advocacy of director independence that led to their adoption. Adoption of these various governance innovations both reflected a cultural change in the expectations of director behavior and helped create the cultural change. Thus the shift in the

138. See Disclosure Regarding Nominating Committee Functions and Communications Between Security Holders and Boards of Directors, Securities Act Release No. 8340, Exchange Act Release No. 48,825, Investment Company Act Release No. 26,262, 68 Fed. Reg. 66,992 (Nov. 28, 2003); see also NYSE, Inc., Listed Company Manual $\S$ 303A.02 (2007); NASDAQ, Inc., Marketplace Rules R. 4350(c)(4) (2007).

139. This perception significantly influenced the Business Roundtable's opposition to the SEC's shareholder ballot access proposal. See, e.g., Letter from Henry A. McKinnell, Chairman, Bus. Roundtable, to Jonathan Katz, Sec’y, Sec. \& Exch. Comm'n (Dec. 22, 2003), available at http://www.sec.gov/rules/proposed/s71903/s71903-381.pdf. 
proportion of independent directors on the board from $20 \%$ in the 1950 s to $75 \%$ by the mid-2000s is more than a superficial increase of nominally identified outsiders: board composition and board attitude have notably shifted toward independence-in-fact.

\section{CHANGING BOARD COMPOSITION: THE SEARCH FOR EVIDENCE THAT IT MAKES A DIFFERENCE}

Evidence that connects the increased presence of independent directors to shareholder benefit is weak at best. The empirical studies on the effects of board composition can be broken down into two types: (1) effects on firm performance, using, variously, accounting measures, stock price returns, and market valuation metrics such as Tobin's $q$; and (2) effects on discrete tasks, such as CEO compensation and termination and decisions in connection with takeovers, whether as acquirer or target. ${ }^{140}$ Teasing out the effects of board composition from the many other factors that affect performance is economically and econometrically difficult, ${ }^{141}$ so the lack of a strong positive connection between board independence and performance is perhaps unsurprising. This has motivated the "discrete tasks" line of research, on the theory that even if ultimate performance effects are hard to find in the data, certain governance actions should have a bottom-line effect. Yet even for discrete tasks, there is only limited evidence that board independence generates differences in board behavior, and the differences are not stark.

\section{A. Uncertain Effect on Firm Performance and Behavior}

\section{Firm performance tests}

The most thorough survey of the empirical evidence on board composition effects is a 1999 paper by Bhagat and Black. In describing efforts to show correlation between firm performance and board independence, they report that

140. The leading surveys are Sanjai Bhagat \& Bernard Black, The Uncertain Relationship Between Board Composition and Firm Performance, 54 Bus. LAW. 921 (1999); Benjamin E. Hermalin \& Michael S. Weisbach, Boards of Directors as an Endogenously Determined Institution: A Survey of the Economic Literature, FRBNY ECON. POL'Y. REv., Apr. 2003, at 7; Jonathan L. Johnson et al., Boards of Directors: A Review and Research Agenda, 22 J. Mgmt. 409 (1996). Bhagat and Black are more precisely focused on the role of independent directors.

141. For example, underperforming firms may add more independent directors in the hope that the governance change will improve performance; on cross-sectional comparison, that causal connection will be blurred. Alternatively, the tests may be underpowered, thus, in the absence of a relatively large impact, performance effects will be obscured by statistical noise. For example, if the average effect were $+\$ 0.01$ per firm for the $25 \%$ of firms that were early adopters of board independence, that would cash out to a nontrivial $\$ 30$ billion across $\$ 12$ trillion in equities but might be undetectable through conventional methodology. (Of course the undetectable effect could, in principle, be negative.) 
"[m]ost studies find little correlation, but a number of recent studies report evidence of a negative correlation between the proportion of independent directors and firm performance-the exact opposite of conventional wisdom." ${ }^{142}$ They include their own 1999 study in those negative studies, with results driven by negative outcomes in firms that have an especially high fraction of independent directors, firms with only one or two insiders. One criticism of cross-sectional studies that regress board composition on performance measures is the potential lag between good governance and the visible effect on performance. Bhagat and Black attempt to address this in a detailed 2001 follow-on study with a large sample and long horizon, but the conclusion is the same: that increasing the degree of board independence does not improve firm performance. ${ }^{143}$

\section{Discrete task tests}

Bhagat and Black's 1999 survey also takes a dim view as to whether boards with a majority (or supermajority) of independent directors do a better job on important discrete tasks undertaken by boards. A possible exception is avoiding financial fraud, where the studies suggest that a predominance of independent directors on the board may make a difference. Here are some important examples of board decisionmaking that test whether board composition matters.

142. Bhagat \& Black, supra note 140 , at 942 ; accord Bhagat \& Black, supra note 17 , at 235-37. The 2003 survey by Hermalin \& Weisbach, supra note 140, reaches a similar conclusion.

In contrast, two other studies find a positive correlation; however, both are methodologically flawed in ways that undercut their conclusion. Baysinger \& Butler, supra note 15, purport to show a correlation between board composition in 1970 and performance ten years later in 1980. A statistically significant persistence of such an effect over such an extended period seems highly unlikely. Statistical significance was tested only with respect to one measure of performance and has not been replicated by other studies. MacAvoy and Millstein argue that prior studies fail to take account of the emergence of the "active board" in the 1990s and that the critical variable is not board composition per se but its attitude. They report that firms with the best boards generate significantly higher returns than all others. Ira M. Millstein \& Paul W. MacAvoy, The Active Board of Directors and Performance of the Large Publicly Traded Corporation, 98 Colum. L. Rev. 1283 (1998). Given their board evaluation measure, the results seem so remarkable as to be improbable. MacAvoy and Millstein focus on the extent to which boards followed the 1992 activist stance of the GM board, as measured by grades (A+ to F) that CalPERS assigned in 1995. CalPERS's grades were based on a board's response to the guidelines fashioned by the GM board, not by activism in practice. In other words, if the board went through a process and adopted GM-like guidelines, it would get an A+. Moreover, there was no systematic correlation for grades below A+ and relative performance. See id. at 1313. These results do not seem robust.

143. Bhagat \& Black, supra note 17. The time horizon is important because of the potential lag between board changes and performance improvements. 


\section{a. CEO terminations}

Weisbach's widely-cited 1988 study of CEO terminations in NYSE-listed firms over the 1974-1983 period concludes "that when boards are dominated by outside directors, CEO turnover is more sensitive to firm performance than it is in firms with insider-dominated boards." ${ }^{\text {"44 }}$ But the effect is relatively minor: for firms in the bottom decile of performance, CEO turnover is roughly $5 \%$ more likely for boards with more than $60 \%$ independent directors than boards with less than $40 \%$. Moreover, during the subsequent period from 1984 to 1993, the board composition effect on CEO turnover disappears. ${ }^{145}$ This suggests that the increasing pressures in the market for control swamped the pro-governance effects of independent directors. Thus Bhagat and Black conclude that, at most, there is "some evidence that independent directors behave differently than inside directors when they decide whether to replace the current CEO”; but the differences are small, and, after taking into accout posttermination stock price studies, it's not clear whether the sign is positive or negative when independents dominate the board. ${ }^{146}$

\section{b. Takeover activity as target}

Evidence is mixed on whether target firms in fact benefit from the theoretical advantages of board independence.

Target gains. Consistent with theory, target firms with majorityindependent boards get a higher bid price. A widely-cited study by Cotter et al. (1997) of tender offers from 1989 to 1992 reports that targets with majority independent boards obtained substantially higher premia (twenty percentage points higher on average) than firms without such boards. ${ }^{147}$ Similarly, Lee et al. find that the presence of a majority-independent board increased shareholder returns upon the announcement of a management buyout. ${ }^{148}$ This suggests that majority-independent boards may be more effective bargaining agents and are less likely to succumb to managerial pressure in the takeover process.

Target defensive measures. Theory would also predict that majorityindependent boards should behave differently in adopting preemptive defensive measures. However, various studies do not find differences in majority-

144. Hermalin \& Weisbach, supra note 140, at 14 (characterizing Michael S. Weisbach, Outside Directors and CEO Turnover, 20 J. Fin. ECON. 431 (1988)).

145. Wayne H. Mikkelson \& M. Megan Partch, The Decline of Takeovers and Disciplinary Managerial Turnover, 44 J. FIN. ECON. 205 (1997).

146. Bhagat \& Black, supra note 140, at 925-26.

147. James F. Cotter et al., Do Independent Directors Enhance Target Shareholder Wealth During Tender Offers?, 43 J. FIN. ECON. 195, 202 tbl.1 (1997) (finding that targets with majority-independent boards received on average a $62 \%$ premium versus a $41 \%$ premium for those without such boards).

148. Chun I. Lee et al., Board Composition and Shareholder Wealth: The Case of Management Buyouts, Fin. MGMT., Spring 1992, at 58, 66. 
independent boards' likelihood of adopting the poison pill, opting out of Pennsylvania's highly protective antitakeover laws, or having a classified board. ${ }^{149}$ Other studies present an inconsistent pattern of board composition effects on stock market returns upon the adoption of defensive measures. ${ }^{150}$ Thus the potential post-bid performance advantages of an independent target board may be undercut by its pre-bid performance, which does not improve the rate at which bids are made.

\section{c. Takeover activity as acquirer}

Acquisitions give rise to many species of managerial agency problems that board independence might better control, such as managerial empire building, over-optimism bias, and winner's curse. But the evidence conflicts on whether firms with independent boards are less likely to make value reducing bids; in any event, the effect is small. Byrd and Hickman (1992) report that majority independent boards deliver marginally better returns to shareholders in bidding for acquisitions. ${ }^{151}$ Although the average announcement-date abnormal return for their whole sample was negative (-1.23\%), the average return for acquirers with majority independent boards was roughly zero (-0.07\%) while return for others acquirers was more negative (-1.86\%). Yet Subrahmanyam, Rangan, and Rosenstein (1997), in a sample of firms from the banking industry, find that abnormal returns are negatively related to the proportion of outside directors. ${ }^{152}$

\section{d. Executive compensation}

Executive compensation decisions arguably present the sharpest clash between shareholder and managerial interests. The empirical evidence on the compensation effects of independent directors is equivocal, with "little evidence that independent directors do a better job than inside directors in

149. See Bhagat \& Black, supra note 140 , at 930 .

150. Compare, e.g., James A. Brickley et al., Outside Directors and the Adoption of Poison Pills, 35 J. Fin. Econ. 371 (1994) (finding positive returns for pill adoption with majority independent board and negative returns without), with Chamu Sundaramurthy et al., Board Structure, Antitakeover Provisions, and Stockholder Wealth, 18 StRAt. MgmT. J. 231, 237 (1997) (finding negative returns increasing with independent directors). See generally Bhagat \& Black, supra note 140 , at 929-30.

151. John W. Byrd \& Kent A. Hickman, Do Outside Directors Monitor Managers?, 32 J. Fin. ECON. 195 (1992) (regressing a sample of 128 tender offer bids from 1980 to 1987). Using regression analysis, the authors also identify a curvilinear relationship between the fraction of independent directors and improved acquirer returns that is positive except at the high end of independence where returns become negative. Interestingly, that inflection point is $60 \%$, a low percentage by today's standards. Id. at 213.

152. Vijaya Subrahmanyam et al., The Role of Outside Directors in Bank Acquisitions, Fin MGmT., Autumn 1997, at 23, 34. The authors also suggest that the regulatory structure of the banking industry may explain the surprising result. Id. at 24. 
establishing CEO pay." "153 One surprising result is that boards with more independent directors are more likely to award "golden parachutes" (change-incontrol severance payments typically equal to approximately three times annual salary and average bonus). ${ }^{154}$ One defense of these plans is that they may reduce managerial resistance to a takeover bid, but a more independent board presumably should be better able to control managers directly.

One implication of the studies is that the definition of "independent" may be insufficiently granular. Core, Holthausen, and Larker (1999) show that executive compensation is positively correlated with the fraction of outside directors and that the percentage of compensation associated with board composition is negatively correlated with firm performance. ${ }^{155}$ Yet what explains these results are the characteristics of the outside directors, in particular, the number of outside directors appointed during the CEO's tenure, the number of "gray directors," and the presence of interlocked directors. ${ }^{156}$ This fits with what compensation practitioners have called the "giraffe effect"- the sharp increase in CEO pay associated with the influx of CEOs or former CEOs on the board and on the compensation committee, in response to pressure to add independent directors in the late 1970s and 1980s.

\section{e. Avoidance of financial fraud}

The best-developed evidence of board composition effects is the positive association between board independence and financial reporting accuracy. The exact channel of this effect is not well-specified, but some studies suggest it could be through the independent audit committee.

A strong negative association between accounting fraud and a more independent board are reported by Beasley ${ }^{157}$ and Dechow, Sloan, and Sweeney, ${ }^{158}$ who compare firms with a high likelihood of having committed

153. Bhagat \& Black, supra note 140 , at 931.

154. See Philip L. Cochran et al., The Composition of Boards of Directors and Incidence of Golden Parachutes, 28 ACAD. MGMT. J. 664, 668 (1985); Harbir Singh \& Farid Harianto, Management-Board Relationships, Takeover Risk, and the Adoption of Golden Parachutes, 32 AcAD. MGMT. J. 7, 20 (1989).

155. John E. Core et al., Corporate Governance, Chief Executive Officer Compensation, and Firm Performance, 51 J. Fin. ECON. 371 (1999).

156. Id. at 388; see also Kevin F. Hallock, Reciprocally Interlocking Boards of Directors and Executive Compensation, 32 J. Fin. \& QuANTITATIVE ANALYsis 331, 332 (1997).

157. Mark S. Beasley, An Empirical Analysis of the Relation Between the Board of Director Composition and Financial Statement Fraud, 71 AcCT. REv. 443, 455 (1996); see also Mark S. Beasley et al., Fraudulent Financial Reporting: Consideration of Industry Traits and Corporate Governance Mechanisms, 14 ACCT. HoRIzONS 441, 452 (2000) (finding a negative relationship between board independence and financial fraud across several industries).

158. Patricia M. Dechow et al., Causes and Consequences of Earnings Manipulation: An Analysis of Firms Subject to Enforcement Actions by the SEC, 13 CONTEMP. ACCT. RES. 
accounting fraud (e.g., targeted by an SEC enforcement action) with control firms. Klein also finds a negative association between board independence and abnormal accruals, often a fraud precursor. ${ }^{159}$ Uzun et al. use a broader definition of fraud and find a similar relationship. ${ }^{160}$

Subsequent studies emphasize the importance of audit committee independence ${ }^{161}$ and even the financial expertise of the board or the audit committee. ${ }^{162}$ These studies, plus the various others that show no independent effect of board composition beyond audit committee effects, ${ }^{163}$ suggest once again that structural elements may be crucial to directors' independence in fact.

\section{Understanding the evidence}

It is thus possible to read the U.S. evidence as suggesting that board independence has only minimal effects on board behavior and shareholder value. In my view, this interpretation would be mostly wrong. First, the anomalous empirical results may have conventional explanations. The strongest explanation is the diminishing marginal returns hypothesis: most of the empirical evidence assesses incremental changes in board independence in firms where there is already substantial independence and after the cultural entrenchment of norms of independent director behavior. ${ }^{164}$ But, as I will argue, the most important effects of the move to independent directors, particularly over the long term, are systematic rather than firm specific and thus are unlikely to show up in cross-sectional studies. One systematic effect, the

1, 21 (1996).

159. April Klein, Audit Committee, Board of Director Characteristics, and Earnings Management, 33 J. ACCT. \& ECON. 375, 387 (2002); see also Biao Xie et al., Earnings Management and Corporate Governance: The Role of the Board and the Audit Committee, 9 J. CORP. FIN. 295, 296, 305 (2003) (finding a statistically significant negative relationship between discretionary current accruals and directors with corporate backgrounds but not other backgrounds).

160. Hatice Uzun et al., Board Composition and Corporate Fraud, Fin. AnAlysts J., May-June 2004, at 33.

161. See Jeffrey Cohen et al., The Corporate Governance Mosaic and Financial Reporting Quality, 23 J. ACCT. LiTERATURE 87, 99-102 (2004) (surveying studies assessing the relationship between governance characteristics and incidences of earnings manipulation and fraud).

162. See Anup Agrawal \& Sahiba Chadha, Corporate Governance and Accounting Scandals, 48 J.L. \& ECON. 371 (2005).

163. See, e.g., Lawrence J. Abbott et al., The Effects of Audit Committee Activity and Independence on Corporate Fraud, MANAGERIAL FIN., Nov. 11, 2000, at 55, 56; Lawrence J. Abbott et al., Audit Committee Characteristics and Financial Misstatement: A Study of the Efficacy of Certain Blue Ribbon Committee Recommendations 3 (Mar. 2002) (unpublished manuscript), available at http://ssrn.com/abstract=319125.

164. Cf. Bernard S. Black et al., Does Corporate Governance Predict Firms’ Market Values? Evidence from Korea, 22 J.L. Econ. \& ORG. 366 (2006) (finding a significant effect in Korea from more independent directors even though such an effect does not appear in the United States). 
lock-in of shareholder value as virtually the exclusive corporate objective, could have benefits for early adopters, but other effects, such as the facilitation of accurate financial disclosure and corporate law compliance, have principally external effects.

\section{a. Tradeoffs}

One explanation for the weak evidence on director independence is a potential tradeoff between the different attributes that insiders and independents bring to a board. Yes, a higher fraction of independent directors may produce outcomes that could be associated with value-increasing governance. But there may well be costs. Inside directors or affiliated directors - outsiders with an interest-may contribute valuable advice and insights that are lost in a thoroughly independent board. ${ }^{165}$ Although the predominant model of board behavior has moved towards the monitoring board and away from the advisory board, boards still participate in the firm's strategic planning and otherwise advise the CEO and the senior management team. If the monitoring and other governance functions are better in a predominantly independent board, perhaps the advising is not as good. ${ }^{166}$

\section{b. Sorting (optimal differences)}

Another explanation for the data is a variant on the tradeoff hypothesis that looks to the diversity among firms. If there is no "one size fits all" for board composition, then the heterogeneity in the board composition data may reflect firms finding their optimal insider/independent mix. Take, for example, the cross-sectional data that regresses firm performance on the fraction of independent directors. Assume that firms differ in the optimal fraction because of firm-specific tradeoffs: for particular firms inside directors or affiliated

165. Compare, e.g., JefFrey PfEFfER \& Gerald R. SAlAnCiK, ThE ExTERnAL Control of Organizations: A Resource Dependence Perspective (1978) (discussing "resource dependence" theory and suggesting that affiliations may help firms obtain critical resources), with A. Burak Güner et al., The Impact of Boards with Financial Expertise on Corporate Policies (Nat'l Bureau of Econ. Research, Working Paper No. 11914, 2006), available at http://ssrn.com/abstract=875673 (suggesting that commercial bankers on boards may lead to excessive debt finance and that investment bankers on boards may lead to acquisitions that reduce firm value). Indeed, even Eugene Fama and Michael Jensen, who argued on behalf of the monitoring role of boards, suggest that some insider presence (beyond the CEO) is valuable as a distinctive source of information for the board and as a proving ground for prospective CEO candidates. See Eugene F. Fama \& Michael C. Jensen, Separation of Ownership and Control, 26 J.L. \& ECON. 301 (1983).

166. Indeed, such a tradeoff in making good acquisition decisions is suggested by the curvilinear relationship found by Byrd \& Hickman, supra note 151, in which acquirer returns start decreasing as the fraction of independent directors exceeds $60 \%$. See also April Klein, Firm Performance and Board Committee Structure, 41 J.L. \& ECON. 275 (1998) (finding that insiders on strategic development committees may increase performance). 
outsiders may be more (less) useful, influenced perhaps by the relevant ownership structure or product market competition that reduces (increases) the managerial agency costs addressed by independent directors. ${ }^{167}$ In any event, in a competitive market, we would expect firms to move toward their optimal governance structure. On this view, the regression results are expectedly economically insignificant — as is the general pattern — but only because out-ofequilibrium governance structures do not persist, not because director independence has little value for many firms.

The weakness, or rather, incompleteness, of the sorting hypothesis (as well as the general tradeoff hypothesis) is that it cannot account for the long-term secular trend towards director independence, a quite radical shift, as noted above, and mostly occurring over only a thirty-year period. The story is not only the increasing average fraction of independent directors in public firms but also the increasing fraction of firms with only one or two inside directors, $90 \%$ according to the $2004 \mathrm{Korn} /$ Ferry Study. It seems unlikely that the local, firmby-firm pursuit of shareholder value could produce such a strong trend.

\section{c. Diminishing marginal returns}

The most persuasive conventional explanation for the nominal results of the general empirical pattern is that director independence may well be positive for shareholder value but that above a critical fraction, the returns are diminishing, and, given the plausibility of firm-specific tradeoffs, sometimes may even be negative. Bhagat and Black, for example, say their negative performance measures are driven by firms with "super-majority" independent boards - instances where the board went beyond majority independent directors to only one or two insiders.

A significant part of the reason for the diminishing marginal returns from greater independence is the important institutional complement of hard and soft control markets that also help control managerial agency problems. In robust control markets managers face ouster for subpar performance, which in turn disciplines managerial performance. As will be elaborated on below, although hostile bids have become rare in the United States following the 1980s, their influence is still ubiquitous, particularly through the pervasive focus on shareholder value. This is built into managerial compensation packages through stock-related compensation, "golden parachutes" that blossom lucratively in a takeover, and termination decisions keyed to lagging stock prices. Moreover, the culture of shareholder value has become entrenched on U.S. boards and, indeed, among managerial elites. There is probably a critical threshold of independent directors that exposes the firm to significant control market

167. For a model of a tradeoff between outside and inside control, see Milton Harris \& Artur Raviv, A Theory of Board Control and Size (Ctr. for Research in Sec. Prices, Working Paper No. 559, 2005), available at http://ssrn.com/abstract=607861. 
pressure, both in the board's willingness to entertain a takeover bid and in the board's willingness to terminate an underperforming CEO. So long as that threshold is achieved, control market pressure has a greater effect than incrementally more vigorous board monitoring that might be associated with more independent directors. ${ }^{168}$

\section{d. Firm-specific vs. systematic effects}

The evidence is also consistent with a view that the main effects of the change in board composition are systematic and that the firm-specific effects are very hard to isolate. In the U.S. environment of substantial ownership by economically motivated institutional investors, a dominant pattern of board independence locks in shareholder value as the corporation's principal objective. ${ }^{169}$ This pattern changes the competitive environment for all firms, regardless of the board structure of any particular firm. Thus any firm-specific effects that might be associated with "early adoption" of greater board independence will be quickly obscured by competitive imitation. Assume, for example, that a firm with a predominantly independent board will be more likely to initiate cost-cutting to gain market share and increase profits. A rival firm, irrespective of board structure, is likely to imitate this pattern for competitive survival. The rival may change its degree of board independence to signal its intention to engage in similar behavior. But the new board composition may in turn lock the second firm into shareholder wealthmaximizing strategies in other areas where it may not yet face a competitive threat. The point is that effects of changing board composition must be measured, from a shareholder point of view, across the economy of firms, particularly as a practice becomes dominant. This is econometrically very difficult.

The evidence is also consistent with changes in board composition as driven by factors that may serve general shareholder objectives, not firm specific factors. In the United States, regulators have turned to independent directors to help assure the reliability of financial disclosure. This began with the call for audit committees staffed by independent directors in the 1970s and culminated in the post-Enron reforms that look to independent directors to take control of critical elements of the disclosure process. ${ }^{170}$ To be sure, better disclosure has firm-specific benefits, insofar as it facilitates market monitoring

168. Note that arguments about thresholds and diminishing marginal effects would play differently in the United States, where a diffuse pattern of ownership leads to managerial agency problems, than it would in most other countries, where concentrated ownership patterns produce controlling shareholder agency problems. A robust control market may constrain managerial agency costs but will not rein in controlling shareholders.

169. See the argument for this claim infra text accompanying notes 245-62.

170. See supra notes 93-102 and accompanying text and infra notes 297-98. 
of managerial performance. ${ }^{171}$ This occurs through more accurate stock price formation that can be used in both intrafirm performance comparisons over time and cross-sectional comparisons with other comparably situated firms. It also occurs through more informative securities analyst evaluation of managerial performance, which can be reflected in narrative form as well in stock-picking advice. But better disclosure also generates benefits for other firms, i.e., interfirm externalities. By providing useful comparative information, it facilitates monitoring of other firms' managements (and thus may improve a rival's performance). It also provides competitively valuable information that other firms can use in their planning (and also may therefore improve a rival's performance). More generally, more accurate disclosure can lead to more informative stock prices, as well as more accurate narratives, that can more efficiently guide the behavior of market actors. In short, if independent directors make the firm's disclosure more reliable, then markets presumably will be allocatively more efficient. Yet none of this systematic effect will appear in cross-sectional studies of firm performance (although the evidence that independent directors do a better job in controlling financial fraud ${ }^{172}$ is consistent with the presence of interfirm externalities).

Finally the evidence is also consistent with changes in board composition that serve social interests that may not directly track shareholder interests. Independent directors may be more likely to promote the firm's compliance with legal norms. Some of the push for independent directors arose from efforts to control bribes and other questionable payments. ${ }^{173}$ Others have looked to independent directors to monitor the corporation's law compliance more generally. If independent directors are effective in this regard, the benefits (which in some cases may come at the expense of the firm's shareholders) have a society-wide reach. These effects, too, are not reflected in conventional empirical studies.

\section{B. Summary of Parts I and II}

Parts I and II have put together three important bodies of evidence on boards of U.S. public firms over the 1950-2005 period: first, the evidence of a strong trend toward an increasing fraction of independent directors; second, the evidence of increasing independence-in-fact for directors and boards; and third, the anomalous evidence that changes in board composition seem to have had no (or little) effect on firm performance as measured cross-sectionally. My argument is that the anomalous performance evidence does not undercut the case for independent directors because the empirical tests are looking in the

171. This discussion, which tracks the general argument for mandatory disclosure, follows Gordon, supra note 82.

172. See supra notes $157-63$ and accompanying text.

173. See infra notes $199-200$ and accompanying text and supra note 30 and accompanying text. 
wrong place. The major performance effects of board independence are systematic; and, as I argue below, the major drivers of the trend toward board independence are systematic as well. The independent board both reflects the shift toward shareholder value as the ultimate corporate objective and locks in the shareholder value criterion for the firm and for the economy of such firms. The independent board is made feasible by stock prices that are increasingly informative because of greater firm-specific disclosure; by enhancing the reliability of the firm's disclosure, the independent board helps to maintain stock price informativeness.

\section{THE RISE OF SHAREHOLDER VALUE, 1950-2005}

This Part traces some of the relevant history over the 1950-2005 period in the changing role of corporate boards, in which the "advising" board was replaced by the "monitoring" board. This compressed account attempts to weave together some of the principal factors that produced this change, but its emphasis is on the co-evolution of shareholder wealth maximization and board independence.

Boards are obviously not a creation of the late twentieth century. Adam Smith addressed the role of boards in the joint stock company and the difficulty in getting directors to monitor appropriately in $1776 .{ }^{174}$ Nevertheless the postWorld War II period has been an especially dynamic period in the history of boards because of the heightened competitive pressures that led to rapid changes in the board's role. The recent history usefully makes us aware both of different potential board functions, not all of which might have been conceived of by Adam Smith, and of the changing weights of the different functions in our conception of the well-functioning board.

The history also makes us aware that many aspects of board function are jointly determined with the corporate purpose. For example, a corporation that evaluates managerial performance almost exclusively in terms of shareholder value will inevitably produce a board in composition and function quite different from a corporation in which managers are charged with trying to balance and in some way maximize total stakeholder value. As a positive matter, in competitive global capital and product markets, the shareholder value

174. Adam Smith, An Inquiry into the Nature and Causes of the Wealth of NAtions para V.1.103 (Edwin Cannan ed., Methuen and Co. 1904) (1776), available at http://www.econlib.org/LIBRARY/Smith/smWN20.html\#B.V,\%20Ch.1 ("Removal from an office which can be enjoyed only for the term of three years, and of which the lawful emoluments, even during that term, are so very small, seems to be the utmost punishment to which any committee-man is liable for any fault, except direct malversation, or embezzlement, either of the public money, or of that of the company; and the fear of that punishment can never be a motive of sufficient weight to force a continual and careful attention to a business to which he has no other interest to attend.”). 
objective is likely to be of greater importance and therefore will drive the conception of the board. ${ }^{175}$

Finally, the history makes us aware that the stance of managers towards boards has changed considerably. In addition to compensation, managers are interested in autonomy, and, generally speaking, an activist independent board encroaches on managerial autonomy. Yet the history shows that as other forces become important, for example, the hostile takeover market or interventionist government regulation, managers embrace the idea of an independent board while in practice often resisting the mechanisms that would generate genuine independence.

This thumbnail sketch of the relevant history can be broken down into five periods, each focusing on a characteristic view of the corporation's most important objective and the board's corresponding function, and the prevalent managerial attitude. In the general trajectory, there is an increasingly tight link between the independent board and the priority of shareholder value.

\section{A. The 1950s: The Heyday of Stakeholder Capitalism and Corporate Managerialism}

The 1950s is famously the high-water mark of managerialism in U.S. corporate governance, in which boards were largely passive instruments of the CEO, chosen by him and strongly disinclined to challenge his decisions or authority. For a 1950s firm, in addition to the profit-making objective, there were two other important elements: first, the impetus to balance among competing stakeholder objectives; second, the role of corporate management as a central planner. Both of these important elements arguably led to an "advisory" board, in which the CEO's trust in the board was critical, rather than a "monitoring" board, in which the board's trust in the CEO was the question.

The 1950s conception of the corporation and the board reflects what was also the post-World War II high-water mark of stakeholder capitalism in the United States. The political climate favored such a conception of the corporation, and the dominant economic position of the United States in the immediate post-war period permitted it. The shared sacrifice of World War II produced a strong national feeling that the fruits of post-war prosperity should also be shared. Organized labor was never stronger, and the demands for employee sharing in enterprise rents enjoyed strong social legitimacy. ${ }^{176}$

175. I mean to bracket for now the question of whether this corporate objective is efficient, and whether other goals might transcend efficiency. Certainly the thrust of current shareholder activism, much of which is propelled by public and union pension funds, is to advance the shareholder value objective. Some may find considerable irony in this.

176. See Kenneth M. Thompson, Human Relations in Collective Bargaining, HARV. Bus. Rev., Mar.-Apr. 1953, at 116, 118-20 (arguing that employees should receive a "fair wage" from their employers, though also asserting that the determination of "fairness" is unresolvable because of divergent values within American society). 
"Pluralism" was the innovation in the political science debate, and the idea of log-rolling-as-sharing (versus creating deadweight loss) enjoyed currency. ${ }^{177}$ Notwithstanding the inevitable battling over the appropriate employee share, managers of large public firms did not reject outright such stakeholder claims. ${ }^{178}$ In part this was because of managers' identification with the ideological contest with communism over which system could provide a better life for the "workers." ${ }^{, 79}$ Moreover, the strong global position of U.S. firmswhich had avoided physical and economic devastation during the war-was a source of rents that managers could allocate away from shareholders without harsh capital market punishment. ${ }^{180}$ Thus a 1961 Harvard Business Review survey of 1700 executives revealed that approximately $83 \%$ of the respondents agreed that "[f]or corporation executives to act in the interests of shareholders alone, and not also in the interests of employees and consumers, is unethical.,181

177. Compare Robert A. DAhl, A Preface to Democratic Theory (1956) (considering log-rolling as pluralist trading), with WiLLIAM H. RIKER, LIBERALISM AGAiNST POPULISM (1982) (considering log-rolling as creating deadweight loss).

178. See Robert N. Anthony, The Trouble with Profit Maximization, HaRv. Bus. Rev., Nov.-Dec. 1960, at 126, 133 ("[W]hereas 50 or 100 years ago the profit maximizing manager would perhaps have been tolerated in some circles of some communities, today society clearly expects the businessman to act responsibly.”); Paul G. Hoffman, The Survival of Free Enterprise, HARV. Bus. REv., Autumn 1946, at 21, 25 (arguing that businesses had the "responsibility," i.e., obligation, to promote employee self-actualization).

179. See Hoffman, supra note 178, at 23, 26 (arguing that the survival of the "free capitalistic economy" depends upon businessmen acting in the general public interest); John W. Welcker, Fair Profit?, HaRv. Bus. REv., Mar. 1948, at 207, 207 (asserting that "[s]ocialistic tendencies in the rest of the world, a critical attitude toward private enterprise here at home, and the development of a feeling of broad public responsibility on the part of American businessmen themselves are all working toward the concept of 'fair profits"”). (2001)

180. Mark J. Roe, Rents and Their Corporate Consequences, 53 StAN. L. REV. 1463

181. Raymond C. Baumhart, How Ethical Are Businessmen?, HARV. Bus. Rev., JulyAug. 1961, at 6, 10. A look at articles published in the Harvard Business Review during this period illuminates the development of this receptiveness to stakeholders. Initially, the legitimacy of stakeholder claims was justified by advertence to the long-term interests of shareholders, which would benefit by increased employee morale and an improved public image. See Frank W. Abrams, Management's Responsibilities in a Complex World, HARV. Bus. REV., May 1951, at 29, 30 (arguing that business firms "can be made to achieve their greatest social usefulness... when management succeeds in finding a harmonious balance among the claims of the various interested groups: the stockholders, employees, customers, and the public at large”); Wallace B. Donham, The Social Significance of Business, Harv. Bus. REV., July 1927, at 406, 415 (emphasizing the benefits of "the good standing of [the] institution" to the bottom line). Such attitudes also may have stemmed from fear of advancing socialism both at home and abroad. However, as time wore on, the interests of stakeholders began to be seen by some as legitimate in their own right, to be balanced even against the long-term interests of the shareholders. See Robert W. Austin, Code of Conduct for Executives, HaRv. Bus. Rev., Sept.-Oct. 1961, at 53 (laying out a code of conduct for executives based on balancing competing stakeholder interests); Gordon Donaldson, Financial Goals: Management vs. Stockholders, HARV. Bus. REV., May-June 1963, at 116, 119 (describing the role of management as arbitration between stockholder interests and 
World War II and the contemporary influence of socialism affected the firm in other ways. The war was waged and won by huge centralized bureaucracies that were able to surmount logistical and planning challenges. These lessons could be applied to the private firm in shaping and managing its environment, it was thought. Moreover, serious intellectual efforts were dedicated to showing how a centralized planned economy—socialism—might successfully function and the advantages that such a system might have over an economy of discrete firms. ${ }^{182}$ Here too the lesson was that bureaucratic rationality could shape and manage a complex economic environment. ${ }^{183}$ Thus one of the purposes of the firm could be said to create, organize, and administer markets within the firm rather than simply to respond to pricing signals provided by markets, particularly the stock markets. ${ }^{184}$

The senior management team, headed by the CEO, was thus perceived as having two tasks: running the centralized planning and production-oversight structures within the firm and then allocating enterprise rents among the various potential claimants on the firm. This conception fit with the idea of an advisory board that included many insiders and outsiders with important economic relationships with the firm, such as bankers, lawyers, and suppliers. Such knowledgeable parties could serve as a useful sounding board for the CEO, a kitchen cabinet, and could provide expertise in the face of increasing

"other interests such as the labor union or the consumer"); J. Elliot Janney, Company Presidents Look at Their Successors, HARv. Bus. REv., Sept.-Oct. 1954, at 45, 49 (claiming that managers "regard themselves as stewards who were responsible to stockholders, employees, customers, and the general public"). See generally Herman E. KROOSs, EXECutive Opinion: What Business LEADERs SAID AND THOUght ON ECONOMIC IsSUES, 1920s-1960s, at 50-53 (1970) (describing the 1950s preoccupation with the concept of "social responsibility").

For other representative statements to similar effect, see many of the essays in THE CORPORATION IN MODERN SOCIETY (Edward S. Mason ed., 1959).

182. See, e.g., Oskar Lange \& Fred M. TAylor, On the Economic TheORY of SociALISM (Benjamin E. Lippincott ed., 1938) (arguing that a socialist government could solve the "calculation problem" by setting shadow prices and, because the central planner would have more information, could do so more efficiently than the market).

183. See, e.g., Arnold J. Toynbee, Thinking Ahead, HARV. Bus. Rev. Sept.-Oct. 1958, at 23, 26 ('[T] association with the notions of enterprise and profit, it is coming to be associated in our minds more and more with the very different notions of administration and organization.”).

184. See, e.g., Adolf A. Berle, Jr., The 20th Century Capitalist Revolution 3132, 40-41 (1954); John Kenneth Galbraith, The Affluent Society (1958); John Kenneth Galbraith, The New Industrial State 5-6, 118, 365 (3d ed. 1978); Robin MARris, THE ECONOMIC THEORY OF 'MANAgerial' CAPITALISM (1964); ANDreW Shonfield, Modern Capitalism: The Changing Balance of Public and Private Power (1965); see also Elmer W. Johnson, An Insider's Call for Outside Direction, HaRV. Bus. REV., Mar.-Apr. 1990, at 46, 47 (noting that a former GM officer observed that a "control mentality [in the 1960s and 1970s] gave top managers great confidence in their ability to predict and control the future”). Indeed, the conglomerate form that rose to prominence in the 1960s relied on a theory about centralized monitoring and capital allocation capacities of the headquarters team. See infra text accompanying notes 305-06. 
complexity. ${ }^{185}$ In an important sense, boards were an extension of management. ${ }^{186}$ Similarly, the 1950s-style board could also play a useful role in finding the right balance to the corporation's mission statement. ${ }^{187}$ Indeed, social commentators such as Peter Drucker argued that board alignment with shareholder interests would undercut the desirable capacity of managers to manage in the public interest. ${ }^{188}$

On this view, a "monitoring board" would inject dissonance and distrust. How could the CEO trust and thus confide in directors whose ultimate mission was to hold him to account? The board selection and nomination mechanism followed upon the managerialist conception of the board's role. If the CEO was looking for trusted advisors who might widen his decisional frame, then it followed that the CEO would play a large role in director selection.

\section{B. The 1970s: The Rise of the Monitoring Board}

The 1970s were characterized by a double disillusionment about corporate performance, and the passivity of directors that contributed to it. There were two powerful shocks: first, the unexpected collapse of Penn Central and second, the Watergate-related illegal domestic campaign contributions and

185. Thus another way to understand the movement from the advisory to the monitoring board is in terms of the rise of consultants, who can better provide cross-industry expertise and strategic counseling than board members recruited by the CEO.

186. Nat’l Indus. Conference BD., Inc., Studies in Business Policy, No. 90: CORPORATE Directorship PRACTICES 5-6, 59 (1959).

187. Margaret Blair and Lynn Stout have developed an alternative "team production" explanation of the stakeholder balancing of the 1950s, one that focuses on the efficiency advantages of a board that acts as a "mediating heirarch" among competing stakeholder claims so as to encourage firm-specific investment, especially by employees. Margaret $\mathrm{M}$. Blair \& Lynn A. Stout, A Team Production Theory of Corporate Law, 85 VA. L. REV. 247 (1999). But cf. John C. Coates IV, Measuring the Domain of Mediating Hierarchy: How Contestable Are U.S. Public Corporations?, 24 J. CoRP. L. 837 (1999).

188. Peter F. Drucker, The New Society: The Anatomy of Industrial Order 340-43 (1950); see also C.A. Harwell Wells, The Cycles of Corporate Social Responsibility: An Historical Retrospective for the Twenty-First Century, 51 U. KAN. L. REV. 77, 99-111 (2002). Andrew Shonfield put the point colorfully in 1965:

Nowadays the manager, who is not the owner, is neither driven into automatic responses by the forces of the market place nor guided by the exclusive desire to make the maximum profit on behalf of his shareholders.... So long as the management of a large public company is reasonably successful at making a profit, it is normally left alone to conduct the business as it sees fit and to appoint its own successors. The position of the shareholders, which is sometimes presented by the ideologues of business in the image of a parliament telling ministers what to do, is in fact much closer to that of a highly disciplined army, which is permitted by law to riot against its generals if, but only if, rations should happen to run out.

SHONFIELD, supra note 184, at 377-78. Even those who were concerned about corporate power and suspicious of management's benevolence did not see a reformed board as a potential counterweight but looked instead, in a corporatist mode, to countervailing power from unions, customers, and various sorts of substantive government regulation. See, e.g., Douglas M. Branson, Corporate Governance "Reform" and the New Corporate Social Responsibility, 62 U. PITT. L. REV. 605, 609 (2001) (discussing John Kenneth Galbraith). 
"questionable payments," (less politely, probable bribes) to foreign government officials. ${ }^{189}$ The bankruptcy of the Penn Central Railroad, regarded as the bluest of blue chips, resonated in its day like the fall of Enron, and the "questionable payments" scandal revealed at least as much rot as the accounting abuses in the late 1990s. The reaction was to push the board away from an advisory model to a monitoring model, at least in aspiration. In a sense, much subsequent corporate governance reform is a working out of the forces put in motion by the 1970s. The decline of insiders on the board and the rise of independents began then; so did the regularization of audit committees.

\section{The Penn Central collapse and the absence of performance monitoring}

The Penn Central story laid bare the failure of the 1950s board conception since it became apparent that the board had little inkling of the financial troubles facing the railroad. The board was simply unaware as to how poorly the railroad had performed. Indeed, as working capital deteriorated and indebtedness escalated in the two years before the collapse, the board nevertheless approved over $\$ 100$ million in dividends. ${ }^{190}$ The Penn Central's directors (and, as it turned out, directors of many other firms) had been neither advisors nor monitors, but figureheads. ${ }^{191}$ Much like Enron's collapse foreshadowed financial frauds at many other firms, the Penn Central collapse preceded other 1970s debacles such as the Equity Funding scandal ${ }^{192}$ and the failures of high-profile firms such as LTV, ${ }^{193}$ Ampex, ${ }^{194}$ and Memorex. ${ }^{195}$

189. A very useful account, with references to original sources, is provided by Joel Seligman, A Sheep in Wolf's Clothing: The American Law Institute Principles of Corporate Governance Project, 55 GEO. WASH. L. REV 325, 328-40 (1987).

190. Joseph R. Daughen \& Peter Binzen, The Wreck of the Penn Central 256, 336 (1971).

191. See Robert Townsend, The Wreck of the Penn Central, N.Y. Times, Dec. 12, 1971, at BR3 (book review). One Penn Central director who joined the board shortly before the collapse described his colleagues this way:

[T] hey sat up there on the eighteenth floor in those big chairs with the [brass name] plates on them and they were a bunch of, well, I'd better not say it. The board was definitely responsible for the trouble. They took their fees and they didn't do anything. Over a period of years, people just sat there. That poor man from the University of Pennsylvania [Gaylord P. Harnwell], he never opened his mouth. They didn’t know the factual picture and they didn’t try to find out.

DAUGHEN \& BinZEN, supra note 190, at 303.

192. Robert J. Cole, Insurance Fraud Charged by S.E.C. to Equity Funding, N.Y. Times, Apr. 4, 1973, at 1; see also William E. Blundell, Equity Funding's Worth Is \$185 Million Less than Firm Had Claimed, Trustee Estimates, WALL ST. J., Feb. 22, 1974, at 6. The way in which the public became aware of the insurance and accounting frauds at Equity Funding set the stage for the famous insider-trading case Dirks v. SEC, 463 U.S. 646 (1983).

193. See LTV Recounts Its Many Ills, Bus. WK., Dec. 19, 1970, at 42.

194. See James E. Bylin, Ampex Expects $\$ 40$ Million Loss for Fiscal 1972, WaLL ST. J., Jan. 12, 1972, at 4; James E. Bylin, The Music Stopped: How Ampex Saturated Recorded Tape Market and Got Soaked Itself, WALL ST. J., Mar. 9, 1972, at 1.

195. Richard R. Leger, Memorex Concedes It's in Financial Morass and that Bank of 
Myles Mace's widely-read book, Directors: Myth and Reality, which appeared in 1971, exposed the pervasiveness of director passivity and underscored the failure of the advisory board model. Based on extensive field research extending over the prior managerialist decades, he declared that the board's putative "advise and counsel” function had only limited impact-“"very rarely" leading "to a reversal of a management commitment or decision.",196 The "discipline" purportedly provided by the CEOs need to be accountable to his board peers was highly attenuated because "managements [knew] from previous experience that members of the board will not ask penetrating,

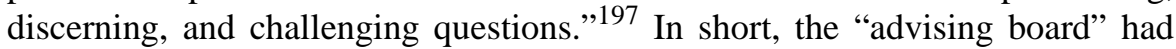
been something like a fraud-simply a way of giving managers the appearance of accountability. ${ }^{198}$

\section{2. "Questionable payments" and the absence of controls monitoring}

The second 1970s shock-the diversion of corporate funds for illicit domestic and foreign advantage - called attention to the board's limited information about the corporation's accounting practices and raised the question about the extent of board responsibility for assuring the corporation's compliance with law. Boards did not think it their responsibility to oversee the firm's accounting or law compliance, to engage in "controls monitoring."

The "questionable payments" scandal unfolded as a consequence of the Special Prosecutor's investigation into the series of abuses known as "Watergate." ${ }^{199}$ More than fifty public firms became the subject of criminal prosecution or SEC enforcement action; another 400 firms, prompted by the threat of prosecution, voluntarily admitted having made illegal campaign contributions or bribes abroad and in the United States. In the aftermath it became clear that while senior corporate officers often knew of these payments, outside directors had not been clued in and were not otherwise "in the loop" of the corporation's internal controls. Inquiry that would lead to such knowledge was beyond the job description of the advising board. This was evident in the Delaware Supreme Court's 1963 exoneration of a board that was unaware of criminal antitrust violations by the corporation: "[A]bsent cause for suspicion there is no duty upon the directors to install and operate a corporate system of espionage to ferret out wrongdoing which they have no reason to suspect

America Has Intervened, WALL ST. J., May 16, 1973, at 4.

196. MACE, supra note 22, at 180.

197. Id.

198. See also EISENBERG, supra note 29, at 170-202 (identifying corporate failures of early 1970s as evidence of the failure of the advising board model).

199. See Seligman, supra note 189, at 333-36; see also Report of the Securities and Exchange Commission on Questionable and Illegal Corporate Payments and Practices, Sec. Reg. \& L. Rep (BNA), No. 353, Special Supplement (May 19, 1976). 
exists." 200 This seemed to give the advising board a free pass on a duty to become informed and monitor.

\section{Corporate social responsibility}

Additional pressure on the advising board model came from a different direction as well, the corporate social responsibility movement fueled in the 1970s by concern about corporations' involvement in the Vietnam War and their policies on the environment, employment, and other social issues. The 1970s social responsibility movement presented a different challenge than the stakeholder claims that traditionally were the main competitor with shareholder claims. In addressing stakeholder claims, the corporation of the 1950s and 1960s was asked to give due weight to the interests of those within the corporate family, most importantly, the employees and the communities in which they lived. ${ }^{201}$ Directly addressing broader social issues was at the margin, a justification for limited charitable giving. ${ }^{202}$ The 1970s movement argued for a broader sense of corporate purpose that would attend to the wellbeing of the general society, not the corporation, even broadly defined, and often asked for much deeper corporate engagement with social problems. ${ }^{203}$

The most common tactic of the social responsibility movement was to try to put forward a shareholder proposal for vote at the annual meeting as a way to call public attention to the issue and to pressure management for an accommodation. This was the heart of the "Campaign GM" approach, ${ }^{204}$ which, as a structural reform measure, also called for liberalization of the SEC rule giving shareholders limited access to the corporate proxy. Other governance reform proposals were much further reaching and focused on the

200. Graham v. Allis-Chalmers Mfg. Co., 188 A.2d 125, 130 (Del. 1963).

201. Indeed, one might distinguish between "corporate stakeholder responsibility" and "corporate social responsibility."

202. E.g., A.P. Smith Mfg. Co. v. Barlow, 98 A.2d 581 (N.J. 1953) (permitting a charitable contribution to Princeton University).

203. Compare Norman A. Adler, The Sounds of Executive Silence, HARv. Bus. Rev., July-Aug. 1971, at 100, 102 ("Even the most profit-motivated stockholder can have no legitimate cause for complaint when the corporation contributes reasonable sums in support of the public weal.”), with Burton G. Malkiel \& Richard E. Quandt, Moral Issues in Investment Policy, HARv. Bus. Rev., Mar.-Apr. 1971, at 37, 38 ("In recent years portfolio managers (especially those of nonprofit private institutions) have been asked to deploy their funds with specific reference to social, political, and moral objectives.”). The corporate social responsibility movement made increasingly broad appeals for corporate action. The call in the late 1960s for the corporation to address urban decay and racial tension may be seen as less far-reaching than the 1970s claims made by the consumer and environmental movements. The former called for plant location and job training decisions well within the corporation's traditional roles; the latter called for a quite different relationship to society. See Wells, supra note 188, at 112-13.

204. See Donald E. Schwartz, The Public-Interest Proxy Contest: Reflections on Campaign GM, 69 MicH. L. REV. 419 (1971). 
board. Nader, Green, and Seligman famously called for federal incorporation of major firms under rules that required full-time directors who were nominated exclusively by disinterested shareholders and that gave weight to board representation of various constituency groups. ${ }^{205}$ There were other calls for socalled "constituency directors.",206

Thus the social responsibility movement and the "monitoring board" movement found common ground on the importance of the independent director, although there was no genuine meeting of the minds. Independent directors who monitored vigorously on behalf of shareholder interests would pursue an agenda quite different from a "constituency director" infused with a broader sense of corporate mission. One irony of the social responsibility movement was its kindred spirit to managerialist claims about the need for appropriate balance in the corporation's objectives. One difference, of course, was the managers' persistent desire for control and autonomy, the exclusive power to strike the balance, without the noisome assistance of constituency directors. So if there was broad support in the 1970s for an infusion of "independent directors" into board activity, there was no crisp consensus on exactly what ends these directors were to pursue.

\section{Reconceptualization of the board}

The cumulative effect of these pressures led, by the end of the 1970s, to a significant reconceptualization of the board's role and structure. First, the advising board model was replaced as aspirational paradigm by the "monitoring board," as presented in Mel Eisenberg's influential 1976 book, The Structure of the Corporation: A Legal Analysis. The new model rapidly became conventional wisdom, endorsed by the Chairman of the SEC, ${ }^{207}$ the corporate bar, ${ }^{208}$ and even the Business Roundtable. ${ }^{209}$ Second, the audit committee, staffed by independent directors, came to be seen as an essential part of the board's monitoring capacity. The SEC initially had made the existence of an

205. See RAlPh NADER ET AL., TAMing THE GIANT CoRPoration 123-28 (1976).

206. See Victor Brudney, The Independent Director-Heavenly City or Potemkin Village?, 95 HARV. L. REV. 597, 598-607 (1982).

207. See Seligman, supra note 189 , at 338 ("What is missing on too many boards is a truly independent character that has the practical capacity to monitor and to change management." (quoting Corporate Rights and Responsibilities: Hearings Before the S. Comm. on Commerce, 94th Cong. 303-04 (1976) (statement of Roderick Hills, Chairman, Securities and Exchange Commission))).

208. See ABA Comm. on Corporate Laws, supra note 31 ("[T] [the] reviewer of management initiatives and monitor of corporate performance ....”).

209. Bus. Roundtable, The Role and Composition of the Board of Directors of the Large Publicly Owned Corporation, 33 Bus. LAw. 2083, 2087, 2092-93 (1978). The Business Roundtable's acceptance of the full entailments of the "monitoring board" should not be overstated. For example, Business Roundtable insisted on the importance of the traditional function of the board as a strategic advisor and the value of inside directors in this context. Id. at 2098, 2107. 
audit committee a matter of disclosure only, but in 1976 requested that the NYSE amend its listing requirements to include an audit committee composed of independent directors with access both to accounting information and to the outside auditors on a private basis. ${ }^{210}$ Ironically by the time the NYSE adopted the requirement, audit committees had become a widely accepted element of board structure, found in almost $95 \%$ of large public companies. ${ }^{211}$ Third, the composition of the board began to shift in favor of independent directors rather than insiders and pressure grew to increase the independence of the nominating committee. ${ }^{212}$ The idea of a "constituency director" never gained real traction, but nevertheless the view persisted that independent directors could help the corporation find that sweet spot where maximizing shareholder welfare over an appropriate horizon could coincide with attention to social interests as well.

The result of the corporate governance reforms of the 1970s might be described as reflecting a mixed strategy, in which managerial elites made significant concessions to address the governance failures revealed by Penn Central's bankruptcy and the questionable payments scandal, but held onto significant managerial prerogative over the composition and function of the board. The rhetoric of the monitoring board and independent directors gained widespread currency, but the work of genuine change in the habits and practices of the board had barely begun. Moreover, the traditional stakeholder balancing as now broadened by the corporate social responsibility movement was employed by managerial elites to counter a potentially single-minded board focus on shareholder welfare that would threaten managerial control. In the midst of the Business Roundtable's 1978 acceptance of the performancemonitoring board, it finds a link between social responsibility and profitability

210. See Seligman, supra note 189, at 338.

211. In 1972, the SEC “endorse[d] the establishment by all publicly held companies of audit committees composed of outside directors.” Standing Audit Committees Composed of Outside Directors, Exchange Act Release No. 33-5237, [1971-1972 Transfer Binder] Fed. Sec. L. Rep. (CCH) I 78,670 (Mar. 23, 1972), 1972 WL 125505. In 1974 and 1978, the SEC adopted rules requiring disclosures about audit committees. Additionally, in 1978, the New York Stock Exchange required all listed securities to have an audit committee composed of non-management members meeting its policy standards. ABA Comm. on Corporate Laws, The Overview Committees of the Board of Directors, 34 Bus. LAw. 1837, 1839 (1979). In 1967, the Conference Board found audit committees at 19\% of manufacturing companies and $31 \%$ of nonmanufacturing companies, as compared to $93 \%$ and $94 \%$, respectively, in 1977. Jeremy BACON, Corporate Directorship Practices: MEMBERShip AND CommitTees of the BoARD 50 (1973) (Conf. Bd. Report No. 588); ABA Committee on Corporate Laws, supra note 208, at 1644 (citing JEREMY BACON, THE BOARD OF DiRECTORS: Perspectives and Practices in Nine Countries (1977) (Conf. Bd. Report No. 728)).

212. The Business Roundtable went so far as suggest that the nominating committee have a "majority of outside directors," i.e., substantial insider representation, but was cold to the idea of shareholder access to the proxy statement for the purpose of nominating directors. Bus. Roundtable, supra note 209, at 2108. For evidence on the shifting composition of the board in the 1970s, see supra Figures 1 and 2 and infra Appendix Table 1. 
as necessary to assure "the political and social viability of the enterprise over time.,213

By contrast, Milton Friedman's 1970 essay, The Social Responsibility of Business Is to Increase Its Profits, ${ }^{214}$ was a scandale because of its unvarnished emphasis on the shareholder value as virtually the sole criterion by which corporate performance should be judged. This view seemed far out of the mainstream.

\section{1980s: The Takeover Movement, Shareholder Value, and the Rise of the Independent Director}

The 1980s were the crucial decade in cementing the connection between independent directors and shareholder value. The decade was marked by an emerging belief about shareholder value as the ultimate measure of corporate success and by the deepening acceptance of a governance model focused on the monitoring board composed of independent directors. The hostile takeover was a catalyst for both developments.

\section{The monitoring board as safe harbor in the "Deal Decade"}

The dominance of the monitoring board model was by no means assured by the end of the 1970s, since its endorsement by managerial elites was at least partially a tactical concession to forestall further reaching reforms, such as national chartering. Indeed, as the national political consensus, as reflected in the presidential and congressional elections, turned away from the critique of corporate power, the Business Roundtable retreated on prior positions. ${ }^{215}$ Yet by the end of the decade managerial elites were aggressively promoting the

213. Bus. Roundtable, supra note 209, at 2099.

214. Milton Friedman, The Social Responsibility of Business Is to Increase Its Profits, N.Y. Times Mag., Sept. 13, 1970, at 32, reprinted in ThOMAs G. MARX, BusinEss AND SOCIETY: ECONOMic, Moral AND Political Foundations 145-50 (1985). Friedman had two points: the first was that the direction of corporate activity other than to maximize shareholder welfare was inefficient; the second was that use of corporate funds for any other purpose amounted to theft from shareholders. For another argument regarding the economic efficiency point, see Eugene V. Rostow, To Whom and for What Ends Is Corporate Management Responsible?, in THE CORPORATION In MODERn SOCIETY, supra note 181, at 46.

215. This was reflected in the Business Roundtable's vehement exception to the American Law Institute's new project on corporate governance, which promised (or threatened) fuller elaboration of the legal entailments of the monitoring board model. See generally Seligman, supra note 189. The attacks included the objection that the ALI's Principles of Corporate Governance "would make every board of directors adopt a monitoring method that cannot work.” Id. at 326 (quoting Andrew Signler, Chairman, Business Roundtable Corporate Responsibility Task Force). Some academics also attacked the monitoring board model. See, e.g., Daniel J. Fischel, The Corporate Governance Movement, 35 VAND. L. REV. 1259 (1982). 
virtues of the monitoring board, since a robust board seemed to offer a safe harbor against the pressure of the takeover movement.

The 1980s became known as the "Deal Decade." Although in aggregate terms, hostile transactions were dominated by friendly deals, the "hostile bid" became a fearful threat. Nearly a quarter of the major U.S. corporations received an unwanted bid. ${ }^{216}$ Many "friendly deals" were negotiated in the shadow of a potential hostile bid. ${ }^{217}$ Even very large firms came under attack from financial buyers whose access to the junk bond market meant they could engineer a highly leveraged transaction that would ultimately be repaid through the sale of various corporate divisions and other assets (a "bust-up"). The stakes never seemed higher for managerial autonomy.

Hostile takeovers in the United States were highly controversial during the 1980s and raise similar controversies in other countries when they appear for the first time. Economists typically describe merger activity as arising from economic adjustment to industry shocks, and in particular have identified some specific shocks as important in the 1980s: deregulation, oil price shocks, foreign competition, and financial innovation. ${ }^{218}$ But the argument that legitimated hostile bids throughout the 1980s was that such activity was a corrective to managerial inefficiency. ${ }^{219}$ The U.S. economy had not thrived in the 1970s, and for the first time it seemed that firms modeled on the U.S. model of managerialist governance were out-competed on the world stage.

The market in corporate control was offered as the cure for economic sclerosis, with both specific and general effects. First, a hostile bid was described as an expression of the competition among management teams for control over the assets of a particular firm. The team that could put the assets to highest and best use would be able to offer the highest price and would prevail. Thus a successful hostile bid would make particular assets more productive. Second, the background threat of a hostile bid would have a disciplining and stimulating effect on other managements. This would lead to more productive use of assets throughout the economy.

An additional factor in the "Deal Decade" (and beyond) was the increasing importance of institutional investors. By 1980, institutions held more than $40 \%$

216. Mark L. Mitchell \& J. Harold Mulherin, The Impact of Industry Shocks on Takeover and Restructuring Activity, 41 J. Fin. ECON. 193, 199 (1996).

217. Often the difference between a "hostile" and a "friendly" bid is just a timing question of when the proposed transaction becomes public. See G. William Schwert, Hostility in Takeovers: In the Eyes of the Beholder?, 55 J. FIn. 2599 (2000).

218. See Gregor Andrade et al., New Evidence and Perspectives on Mergers, $15 \mathrm{~J}$. ECON. PERSP., Spring 2001, at 103, 108.

219. See, e.g., William E. Fruhan, Jr., Corporate Raiders: Head'em Off at Value Gap, HARV. Bus. REV., July-Aug. 1988, at 63 ("[R]aiders and arbitrageurs . . . are a symptom of the large value gaps that persist throughout corporate America”); Peter D. Goodson \& Donald J. Gogel, Managing as if Shareholders Matter, HARV. Bus. REV., May-June 1987, at 24, 26 ("The economics behind the takeover phenomenon are simply too powerful."). 
of the value of U.S. equity markets, concentrated in the largest firms. ${ }^{220}$ This created a class of shareholders singularly focused on shareholder value and quite willing, indeed eager, to sell to a bidder offering a significant market premium. In part this was because institutional investors observed that target managements' claims that the bid was "low ball," that higher values were just around the corner, rarely proved out. ${ }^{221}$ In part the eagerness to sell was because institutional investment performance was often assessed on the basis of a relatively short track record. For example, a mutual fund marketed itself on the basis of annual performance; a money manager for a pension fund or an endowment benchmarked itself against an unmanaged index, or against peers, often on a quarterly basis. ${ }^{22}$ Moreover, institutions were crucial funding sources for financial buyers. Some provided equity capital to buyout firms; others purchased the indebtedness that financed leveraged acquisitions. Early in the cycle, the return from such investments was spectacular. ${ }^{223}$ This, in turn, drew in even more money.

Obviously many incumbent managers disagreed with the efficiencyenhancing justification for hostile takeovers, instead seeing such activity as driven by control arbitrageurs looking for quick profits through the exploitation of stock market mispricing and other quick-buck strategies. Even worse, many managers argued, an active market in corporate control was itself a cause of inefficiency, because of the "short-termism" induced in managerial time horizons. ${ }^{224}$ Instead, the key to the European and Japanese success, they alleged, was "patient capital."225 Nevertheless, hostile bids were powerful phenomena; what to do?

In this environment, managers turned to the monitoring board and to independent directors as the best available protection against the hostile takeover movement, despite the encroachment on managerial autonomy. First, business elites needed a credible board-centered governance mechanism to address performance issues in substitution for the market-centered approach

220. For time-series information on institutional ownership, in absolute terms and as a fraction of U.S. public equity, see infra Table 4 and Figure 6 in the Appendix.

221. See Michael Bradley et al., The Rationale Behind Interfirm Tender Offers: Information or Synergy?, 11 J. FIn. ECON. 183 (1983).

222. See Michael Useem, Investor Capitalism: How Money Managers are Changing the FACE OF CORPORATE AMERICA (1996).

223. See Steven Kaplan, The Effects of Management Buyouts on Operating Performance and Value, 24 J. FIN. ECON. 217 (1989).

224. See, e.g., Warren A. Law, A Corporation Is More than Its Stock, HARV. Bus. REV., May-June 1986, at 80, 81 (arguing that managers have "resisted debt until prodded by takeover fears" because of their long-run view as opposed to the short-run view of investors).

225. E.g., Michael E. Porter, The Competitive Advantage of Nations 528-29 (1990); Martin Lipton \& Steven A. Rosenblum, A New System of Corporate Governance: The Quinquennial Election of Directors, 58 U. CHI. L. REV. 187, 201-24 (1991); Michael E. Porter, Capital Disadvantage: America's Failing Capital Investment System, HaRV. Bus. REV., Sept.-Oct. 1992, at 65. 
associated with the hostile tender offer. What was the answer, after all, to institutional and other shareholders who might strongly suspect management's motives in resisting a hostile bid? The blessing of takeover resistance by independent directors who would, in theory, independently evaluate the adequacy of the hostile bid against the firm's "intrinsic value," was an indispensable part of the legitimating mechanism. ${ }^{226}$ But note that management's (and then the board's) objection to the hostile bid was almost invariably framed in terms of shareholder value: the unwanted bid "undervalued" the target, from the shareholder point of view. ${ }^{227}$

Second, independent directors also provided legal cover under the developing Delaware fiduciary standards for resistance to a hostile bid. (Delaware's standards were important because of the number of large public firms incorporated there and because of Delaware's leadership role in the fashioning of fiduciary duty law.) In a series of pivotal cases, the Delaware Supreme Court permitted a target board to "just say no" to a hostile bid. ${ }^{228}$ Boards were permitted to adopt and maintain a so-called "poison pill," a clever corporate finance artifice that imposed potentially ruinous costs on a hostile bidder. But judicial approval of such measures appeared to be tied to informed decisionmaking by independent directors. And the conditions of director independence became more stringent throughout the period.

\section{Judicial promotion of director independence}

Director independence was a touchstone of Delaware takeover cases even before the tumultuous 1980s, but it became especially critical then because of the extraordinary, unprecedented measures undertaken by targets to thwart hostile bids. The courts were faced with unpalatable choices: prohibit tactics such as the poison pill and leave the matter of corporate control to shareholder action, which Delaware law otherwise strongly constrained; ${ }^{229}$ give managements unbridled discretion to resist hostile bids, which raised obvious conflict problems; or put it to courts to decide on the reasonableness of

226. E.g., Martin Lipton, Takeover Bids in the Target's Boardroom, 35 Bus. LAw. 101, 119-22 (1979); Ira M. Millstein, The Evolution of the Certifying Board, 48 Bus. LAw. 1485, 1493-95 (1993).

227. As discussed below, managements (and boards) almost always declined the gambit of state "constituency statutes" (and language in Unocal Corp. v. Mesa Petroleum Co., 493 A.2d 946 (Del. 1985)) that would have permitted invocation of the interests of nonshareholder constituents. See infra note 237.

228. For a doctrinal account, see Jeffrey N. Gordon, Corporations, Markets, and Courts, 91 Colum. L. Rev. 1931 (1991). See also Alan R. Palmiter, Reshaping the Corporate Fiduciary Model: A Director's Duty of Independence, 67 TEX. L. REv. 1351 (1989).

229. See, e.g., Del. CodE AnN. tit. 8, §§ 141(a), 251(b) (2007). See generally Jeffrey N. Gordon, Shareholder Initiative: A Social Choice and Game Theoretic Approach to Corporate Law, 60 U. CIN. L. REV. 347 (1991). 
takeover defenses in particular transactions, which would transform courts into economic regulators. By contrast, placing the onus on the board of directors had a statutory base, ${ }^{230}$ a doctrinal foundation, ${ }^{231}$ and might thread the needle of the warring parties with conflicting agendas. Yet the 1970s were too fresh to permit casual assumptions about board diligence if the Delaware courts wanted to mollify key pro-takeover constituencies such as institutional investors and the federal government. ${ }^{232}$ Thus we saw a strategy emerge in which the court policed not only board process but also director independence.

The invocation of board independence was a critical component in the sustaining of unprecedented defensive measures in the two pivotal takeover cases of the 1980s, Unocal Corp. v. Mesa Petroleum Co. ${ }^{233}$ and Moran v. Household International, Inc. ${ }^{234}$ In Unocal, which sustained a self-tender that (remarkably) discriminated against a significant shareholder, here, the raider, the Delaware Supreme Court repeatedly invoked the role of the independent directors in the board's evaluation of the raider's bid and the particular defensive measures: the independent directors constituted a majority (eight of thirteen) of the board, the board heard from independent experts, the independent directors met privately with financial advisors and attorneys and met privately together, and the board unanimously agreed on the measures. ${ }^{235}$ This focus on independence-in-fact was a development from prior doctrine. ${ }^{236}$ It was not merely that a majority of the directors were independent, in the sense of no personal pecuniary interest, but that the independent directors had played an independent role in reviewing and approving the defensive undertaking. ${ }^{237}$

230. Section 141(a) of the Delaware Code says, "The business and affairs of every corporation organized under this chapter shall be managed by or under the direction of a board of directors ....” DEL. CoDE ANN. tit. 8, § 141(a) (2007)

231. See Cheff v. Mathes, 199 A.2d 548 (Del. 1964). The defensive measure in question was an early instance of "greenmail," in which the target repurchased a putative raider's $17.5 \%$ block at an above-market price to end a takeover threat. In holding that such use of corporate funds was valid unless the board "acted solely or primarily because of the desire to perpetuate themselves in office," $i d$. at 554 , the court provided a roadmap of how a board could show that a defensive measure was "primarily in the corporate interest," id. (quoting Bennett v. Propp, 187 A.2d 405, 409 (Del. 1962)). Because only two of seven directors had a "personal pecuniary interest" in the board's decisions, the board was not held to the "self-dealing" standard, id., and could satisfy its burden simply "by showing good faith and reasonable investigation," id. at 555, the now-standard formulation of the business judgment rule. In other words, the presence of (relatively) independent directors insulated the corporation and its management from attack for a deal-stopping defensive measure.

232. See Mark J. Roe, Delaware's Competition, 117 HARV. L. ReV. 588 (2003) (describing Delaware's responsiveness to the federal government's pro-takeover stance).

233. 493 A.2d 946 (Del. 1985).

234. 500 A.2d 1346 (Del. 1985).

235. See Unocal, 493 A.2d at 950.

236. See also supra note 231 and accompanying text; cf. Cheff, 199 A.2d 548.

237. As to why the Unocal court rested so heavily on the mechanics of independent director scrutiny — rather than the mere fact of an independent majority-there are at least two related explanations. First, the court might have been influenced by the 1970s debates 
Similarly, in Moran, which validated the implementation of a poison pill, the court noted approvingly the independence of the directors and described the process of director deliberation. ${ }^{238}$ A majority of the board (ten of sixteen) were independent, and all but two of the independent directors (one of whom was contemplating a leveraged bid for the firm) voted for the plan. The directors extensively discussed the shareholder rights plan with the corporation's financial advisors and counsel, illuminated by debate with the particular independent director who opposed the plan most vigorously. The board had the burden of showing that the defensive measure was "reasonable in relation to the threat posed",239 but "that proof is materially enhanced... where, as here, a majority of the board favoring the proposal consisted of outside independent directors who have acted in accordance with the foregoing standards." 240

Perhaps most tellingly, in Paramount Communications, Inc. v. Time, Inc. ${ }^{241}$ the pivotal 1990 case that opened the way to a "just say no" defense, ${ }^{242}$ the Delaware Supreme Court opened the opinion with an elaborate description of the directors, ${ }^{243}$ in particular the independents (twelve of sixteen), and then emphasized throughout the independents' decisionmaking role. After Paramount's bid, Time's independent directors met frequently in executive session, both among themselves and with the corporation's financial advisor and legal counsel, we are told. ${ }^{244}$ Indeed, the court's narrative presents the board as the protagonist of Time's strategy and choices, as opposed to, say, the CEO who was actually driving the Warner merger. Thus the court invokes the engagement of independent directors as a key element in a remarkable legal conclusion: that a target may adopt preclusive defensive measures to block an

about the activist role of independent directors (as embodied in the then ongoing work of the ALI corporate governance project). Second, the court might have been looking for as much cover as possible for the genuinely radical step of permitting corporate action that discriminated against a shareholder. The court was of course disingenuous in asserting that the discriminatory self-tender in Unocal was just a version of the targeted repurchase permitted in Cheff $v$. Mathes, which "discriminated" by giving the raider a selling opportunity not available to other shareholders. This analogy omitted a critical difference. In Cheff, the discriminated-against shareholders purportedly benefited from the greenmail payment, because it drove away a bidder who was offering too low a price, and was undertaken by their agent, the board, whose interests were aligned with theirs. In Unocal, the discriminated-against shareholder, Boone Pickens/Mesa Petroleum, did not benefit, indeed was the target of the discrimination by a board consciously acting against his interests. In other words, the distortion of traditional corporate antidiscrimination norms could be defended as truly necessary to protect the corporation and its other shareholders only because of the heightened independence in fact as well as in form of the Unocal board.

238. 500 A. 2 d at 1348 n.2, 1356.

239. Id. at 1356 (quoting Unocal, 493 A.2d at 955).

240. Id.

241. 571 A.2d 1140 (Del. 1990).

242. See Gordon, supra note 228, at 1944-45.

243. Paramount, 571 A.2d at 1143.

244. Id. at 1147-48. 
all-cash, all-shares bid at a substantial premium to market. The lesson to a planner was clear. The price of the power to "just say no" to a hostile bidder was a board that consisted of a majority of independent directors and a process that would call on those directors to exercise (at least the appearance of) independent judgment. ${ }^{245}$

\section{Summary}

The hostile takeover movement of the 1980s brought unprecedented emphasis to shareholder value as the ultimate corporate objective. In response, director independence came to be understood as a critical element in the intellectual and legal architecture necessary to preserve managerial autonomy against the pressure of the market in corporate control. A managerial elite that in prior decades had no use for independent directors now embraced them as an essential element of shareholder capitalism. The reformers' case for independent directors in the 1970s pointed in several different directions. The takeover movement of the 1980s crystallized that the independent directors' role would be crucially tied to shareholder value.

\section{The 1990s: The Triumph of Shareholder Value and the Independent Board}

\section{Introduction}

In the 1990s the independent board came to be heralded as the solution to a three-way paradox. First, shareholder wealth maximization gained increased acceptance as the ultimate corporate objective and also the ultimate measure of managerial performance. Second, business elites were increasingly successful in persuading the courts to permit far-reaching defensive measures against a hostile bid, a driver of shareholder wealth maximization. And third, hostile bids came to be seen as too costly a way of solving the managerial agency problem. The independent board could resolve this trilemma by benchmarking managerial performance in terms of stock market prices. This was expressed in both executive compensation contracts that heavily used stock-based compensation and in greater reliance on stock market returns in CEO termination decisions. These moves, in turn, produced two immediately visible developments: first, the highest level of CEO compensation in U.S. business

245. The Delaware Supreme Court also excoriated nominally independent directors who had not fulfilled their role of vetting and legitimating what would otherwise be a conflicted transaction, most notably in the management buyout case Mills Acquisition Co. $v$. MacMillan, Inc., 559 A.2d 1261, 1280 (Del. 1989):

The board was torpid, if not supine, in its efforts to establish a truly independent auction, free of Evans' interference and access to confidential data. By placing the entire process in the hands of Evans, through his own chosen financial advisors, with little or no board oversight, the board materially contributed to the unprincipled conduct of those upon whom it looked with a blind eye. 
history and second, the shortest average CEO tenure. In this way the independent board helped lock in shareholder value as the guide for management behavior.

\section{Shareholder value without hostile bids}

The 1980s had a somewhat paradoxical legacy. On the one hand, the shareholder value criterion became increasingly influential, yet hostile bids-a straightforward application of the shareholder value principle-became more difficult as a legal matter and came under some challenge as a business strategy. As the 1990s progressed, managerial elites were increasingly successful in persuading the courts to permit far-reaching defensive measures against a hostile bid. For example, in a series of cases culminating with Unitrin, Inc. v. American General Corp. in $1995,{ }^{246}$ the Delaware Supreme Court seemed to narrow the conception of a "preclusive," and thus legally objectionable, defensive measure to a limited realm of interference with the shareholder franchise. Almost anything else was permitted, giving the target management (assuming the board agreed) a virtual veto over a hostile bid. ${ }^{247}$

Indeed, the economic failure of many high profile late-1980s contested transactions-highly leveraged deals, financed in part with exotic debt securities dumped on junk bond mutual funds-had damaged the business credibility of hostile bids generally. ${ }^{248}$ The post-1980s conventional wisdom was that the hostile bid was a high cost mechanism to solve the managerial agency problem. Where the raider was a "financial" bidder, a 1980s pattern, the hostile bid could disrupt the target's business, distract management, and often end in a financial crisis that reduced organizational rents. Where the raider was a "strategic" corporate bidder, a 1990s pattern, a hostile bid often proceeded in

246. 651 A.2d 1361, 1382 (Del. 1995).

247. As a practical matter, the veto was much more effective in the case of a classified board than otherwise, because of the interaction between the poison pill and classification. In the case of a board elected at a single election, the board veto could be readily overridden by coupling a proxy contest to a conditional bid. A classified board makes an override much tougher, since the electoral coalition that would replace the vetoing board with one that would accept the bid must hold together over two election cycles. See Jeffrey N. Gordon, "Just Say Never?" Poison Pills, Deadhand Pills, and Shareholder-Adopted Bylaws: An Essay for Warren Buffett, 19 CARDOZO L. REv. 511 (1997). In Moore Corp. v. Wallace Computer Services, Inc., 907 F. Supp. 1545 (D. Del. 1995), a federal district court purporting to apply Delaware law permitted a classified target board to maintain its poison pill even after the insurgents had prevailed in an initial election. But as the recent Oracle v. PeopleSoft litigation demonstrated, the validity of such resistance is an open matter of Delaware law.

In other jurisdictions, statutory innovations protected managerial autonomy. For example, boards were given explicit permission in "constituency statutes" to balance the interests of the competing corporate stakeholders; shareholders need not be privileged.

248. See, e.g., Berkshire HathawAy, Inc., 1989 Annual Report (1990), quoted in Ronald J. Gilson \& Bernard S. Black, The Law and Finance of Corporate ACQUISITIONS 438-40 (2d ed. 1995). 
a relatively impoverished information environment, which reduced the chances of a successful bidder/target match. Moreover, the transaction costs associated with a hostile takeover meant that they could directly address only cases of a substantial shortfall in managerial performance and such visible "lumpiness" might reduce the general deterrence effects.

Underlying the concern about hostile bids was also a nagging suspicion that unfettered control markets might be subject to "common mode failure," meaning a ubiquitously adopted innovation that proved, in the end, disadvantageous. For example, adding significant leverage to the capital structure initially seemed to be a value-creating innovation with wide application, ${ }^{249}$ but the troubles that plagued many later deals and the rate of reverse $\mathrm{LBOs}^{250}$ seemed to indicate strong limits. It was apparent that the mergers and acquisitions market was subject to fads and fashions. A successful transaction in an industry spurred imitators long before the value of the new configuration proved out. ${ }^{251}$ The concern was that if the barriers to a hostile takeover were too low, raiders could quickly pursue a takeover of a firm that was not following the current conventional wisdom, in effect treat a nonconforming firm as an arbitrage opportunity — and that this threat would, in turn, make managers too responsive to consensus opinion. ${ }^{252}$ This sort of critique was in the spirit of skepticism about the allocative validity of the efficient market hypothesis that increased after the 1987 stock market break. ${ }^{253}$ The implication was that some friction was desirable in the control markets to slow down the transmission of a structural or strategic innovation so that its virtues might be tested over some meaningful period.

Nevertheless the shareholder value criterion was ascendant, an increasingly powerful guide to managerial behavior. In significant measure this was fueled by the shareownership and activism of institutional investors, who benchmarked managerial performance in shareholder value terms. ${ }^{254}$ Indeed, one of the most striking trends throughout the 1950-2005 period was the rise of

249. See, e.g., Michael C. Jensen, Eclipse of the Public Corporation, HARV. Bus. REv., Sept.-Oct. 1989, at 61.

250. See, e.g., Steven N. Kaplan, The Staying Power of Leveraged Buyouts, 29 J. FIN. ECON. 287 (1991).

251. Steven N. Kaplan \& Bengt Holmstrom, Corporate Governance and Takeovers in the United States: Making Sense of the 1980s and 1990s, 15 J. ECON. PersPeCtives, Spring 2001 , at 121.

252. See Gordon, supra note 130.

253. See generally ANDREI ShleIfER, InEFFICIENT MARKETS: An INTRODUCTION to BEHAVIORAL FINANCE (2000).

254. See generally USEEM, supra note 222; James M. Tobin, The Squeeze on Directors-Inside Is Out, 49 Bus. LAW. 1707 (1994). The role of institutions was buttressed by the SEC's 1992 proxy rule reforms that made it easier for institutions to confer and to influence shareholder votes without incurring the expense of a proxy filing. See 17 C.F.R. $\S 240.14 a-1(2)$ (2007). On institutional investor activism generally, see Bernard S. Black, Agents Watching Agents: The Promise of Institutional Investor Voice, 39 UCLA L. REV. 811 (1992). 
institutional ownership, both in absolute terms and as a percentage of public traded stock. ${ }^{255}$ Institutional investors publicly targeted firms that underperformed, ${ }^{256}$ strongly backed stock-based compensation for senior management to align their interests with shareholders, ${ }^{257}$ and organized "just vote no" campaigns in director elections to protest continued poor performance. $^{258}$

But no less significantly, the maximization of shareholder value as the core test of managerial performance had seeped into managerial culture. The nod to "corporate social responsibility" in the 1978 Business Roundtable statement on corporate governance was omitted from the comparable 1997 statement. Instead, we are given to understand that "the paramount duty of management and of boards of directors is to the corporation's stockholders; the interests of other stakeholders are relevant as a derivative of the duty to stockholders."259 Managerial elites rejected the invitation tendered by so-called "constituency statutes" adopted by many states in the heat of the takeover movement that specifically countenanced the balancing of stakeholder and shareholder interests. ${ }^{260} \mathrm{~A}$ shareholder-oriented focus seemed part of the necessary restructuring of the American economy in a more competitive world. ${ }^{261}$ It also

255. Figure 6 in the Appendix vividly illustrates the increasing growth of institutional ownership, both in absolute amount and as a percentage of publicly traded stock of U.S. firms. See also Appendix Table 4.

256. See Steven L. Nesbitt, Long-Term Rewards from Shareholder Activism: A Study of the "CalPERS Effect," 6 J. APPLIED CORP. Fin., Winter 1994, at 75 (describing campaign by California Public Employees Retirement System and its purported performance effects).

257. See, e.g., James E. Heard, Executive Compensation: Perspective of the Institutional Investor, 63 U. CIN. L. REV. 749, 766 (1995) (noting institutional focus has not been on level of executive compensation but on aligning "pay and performance"); CalPERS, Why Corporate Governance Today? (Aug. 14, 1995), available at http://www.calpersgovernance.org/viewpoint/default.asp.

258. See Grundfest, supra note 91 (advocating a "just vote no" campaign to symbolically chastise underperforming management).

259. Compare Bus. Roundtable, supra note 209, at 2099 (identifying "corporate social responsibility" as a discreet function of the board of directors, where " $t$ the owners have an interest in balancing short-range and long-term profitability, in considering political and social viability of the enterprise over time”), with Bus. Roundtable, Statement on Corporate Governance (Sept. 1997) [hereinafter 1997 BRT Statement], available at http://www.businessroundtable.org/pdf/11.pdf.

260. See ABA Comm. on Corporate Laws, Other Constituencies Statutes: Potential for Confusion, 45 Bus. LAw. 2253, 2268-69 (1990) (rejecting effort to sever management action from shareholder welfare because it "would conflict with directors' responsibility to shareholders and could undermine the effectiveness of the system that has made the corporation an efficient device for the creation of jobs and wealth"). Ironically constituency statutes have often in practice worked out to the detriment of the stakeholders they purport to protect. Managers who have invoked these statutes to resist a takeover bid typically accede after the bidder raises its price; but this additional benefit for the shareholders of course puts more financial pressure on the bidder to cut jobs or wages at the target.

261. See Jeffrey N. Gordon, Employees, Pensions, and the New Economic Order, 97 COLUM. L. REV. 1519 (1997). 
seemed to fit an historical moment in which maximizing the overall size of the pie had greater acceptance than distributional considerations. ${ }^{262}$ By the end of the 1990s, the triumph of the shareholder value criterion was nearly complete.

\section{Resolving the paradox through the market for managerial services}

So now we come to the paradox: serving shareholder value was paramount, yet a major force for addressing the managerial agency problem, the hostile takeover, was off the table. The 1990s board undertook to solve the dilemma by focusing on the market in managerial services, employing three strategic elements: executive compensation contracts, termination decisions, and severance packages. All three mechanisms were designed to build in the pursuit of shareholder value into managerial behavior.

\section{a. Executive compensation}

The first strategy was to fashion executive compensation contracts that better aligned managerial and shareholder objectives, to give managers highpowered incentives to maximize shareholder value. ${ }^{263}$ In light of other institutional constraints, this meant stock options. Both tax and accounting rules favored the use of "plain-vanilla" stock options, meaning immediately exercisable, at-the-money options on the company's stock. Such options were taxable to the executive only when exercised, not when issued; the grant of such options did not reduce the corporation's net income (in other words, they were not expensed). The consequence was to work a revolution in managerial compensation over the period. ${ }^{264}$ For example, the composition of CEO compensation in the largest firms, as reflected by the S\&P 500, shifted over the

262. Id. at 1520,1534 (discussing evidence on increased income inequality in the United States). The well known empirics show decreasing inequality in the two immediate post-WWII decades and increasing inequality thereafter. On most standard indices, inequality sharply increased in the 1990s. See U.S. Census Bureau, Press Briefing on 2001 Income and Poverty Estimates, Chart 12 (Sept. 2002), available at http://www.census.gov/ hhes/www/img/incpov01/fig12.jpg; see also U.S. Census Bureau, The Changing Shape of the Nation's Income Distribution, 1947-1998 (June 2000), available at http://www.census.gov/prod/2000pubs/p60-204.pdf (including several methods to show accelerating inequality in the 1990s). The focus on shareholder value could be the variable that links the rise of income inequality to the rise of director independence.

263. This was consistent with the advice of academic observers, who had contended that managers were "paid like bureaucrats," meaning that their pay was increasing with the size of their organization and was relatively insensitive to performance. See, e.g., Michael C. Jensen \& Kevin J. Murphy, CEO Incentives-It's Not How Much You Pay, But How, HaRv. Bus. Rev. May-June 1990, at 138; Michael C. Jensen \& Kevin J. Murphy, Performance Pay and Top-Management Incentives, 98 J. PoL. Econ. 225 (1990). But see Brian J. Hall \& Jeffrey B. Liebman, Are CEOs Really Paid Like Bureaucrats?, 113 Q.J. Econ. 653 (1998).

264. Some of this Part follows Gordon, supra note 82. 
$1992-2000$ period from $27 \%$ in stock options to $51 \%$ in stock options. ${ }^{265}$ Using a broader definition of equity-based compensation that includes stock grants, the stock-related portion of compensation for so-called "New Economy" CEOs shifted over the same period from $34 \%$ to $83 \%$, and for other CEOs, from $25 \%$ to $59 \% .{ }^{266}$ This had two pronounced effects: first, it led to unprecedented levels of CEO compensation, ${ }^{267}$ but second, it also produced compensation packages that, more than ever, embedded an explicit focus on shareholder value. ${ }^{268}$

\section{b. CEO termination}

The second strategic element of the 1990s boards' focus on shareholder value was increasingly to evaluate CEO performance with respect to shareholder returns and to terminate more quickly. This view seems to have been accepted even among the managers whose tenures were therefore at greater risk. ${ }^{269}$ The change in board behavior is borne out by a number of

265. See Kevin Murphy, Explaining Executive Compensation: Managerial Power Versus the Perceived Cost of Stock Options, 69 U. CHI. L. REV. 847, 848 fig.1 (2002) (calculating valuations in 2001 dollars). The options were valued as of the grant day using a modified version of the standard Black-Scholes option pricing model, which will yield a much lower figure than the value of the option when exercised after substantial market appreciation. This latter figure is the one that is typically reported by the business and popular press. See also Brian J. Hall \& Kevin J. Murphy, Stock Options for Undiversified Executives, 33 J. Acct. \& ECON. 3 (2002); Michael C. Jensen \& Kevin J. Murphy, Remuneration: Where We've Been, How We Got to Here, What Are the Problems, and How to Fix Them 26 fig.2, 31 fig.3 (European Corporate Governance Inst., Finance Working Paper No. 44/2004, 2004) available at http://ssrn.com/abstract=561305.

266. Kevin J. Murphy, Stock-Based Pay in New Economy Firms, 34 J. Acct. \& ECON. 129, 132-33 (2003).

267. BEBCHUK \& FRIED, supra note 109 , at 1.

268. This shift to accept stock-based compensation was facilitated by a historical contingency. To address “unearned excesses” in managerial compensation, Congress in 1993 adopted a "reform" that would deny a public corporation a business deduction for compensation greater than $\$ 1$ million, unless the compensation is paid "solely on account of the attainment of one or more performance goals.” I.R.C. § 162(m) (2007). In effect, the tax code placed a $\$ 1$ million cap on salary and discretionary bonus payments and required a showing that additional compensation was performance-based. One very clear qualifier was a stock option plan using plain-vanilla options, see id. § 1.162-27(e)(2)(vi), and it was a virtual corollary that any level of stock option grant would qualify as "performance-based," since the value of the option was increasing the stock price. Moreover, since plain-vanilla options were not expensed, their grant was "free" to the corporation. By contrast, a cash bonus geared to accounting or other measures would be expensed. Thus, boards would predictably be more generous in stock option grants than other performance-related compensation that might not have such a sharp shareholder value focus. In sum, the tax reform deprived managers of large flat salaries, but in trade for allegiance to the shareholder value criterion, it held out the promise of higher compensation overall.

269. For example, in its 1997 Statement on Corporate Governance, the Business Roundtable, an association of 200 CEOs, stated that "the principal objective of a business enterprise is to generate economic returns to its owners" and that "good corporate governance practices provide an important framework for a timely response by a 
empirical studies. A study by Booz Allen Hamilton of CEO turnover in the 1995-2001 period for the 2500 largest companies worldwide shows a near doubling in the 1995 versus 2000 CEO turnover rate and a trebling of the rate of explicitly performance-related turnovers (twenty-five in 1995 versus eighty in 2000). The study indicates that stock prices had become the bellwether performance measure. ${ }^{270}$ Its "first and most obvious[]" conclusion is that

CEOs must deliver acceptable and consistent total returns to shareholders. In the U.S. and Europe, the growing democratization of shareholding has clearly placed total shareholder returns higher on the management and board agenda than it was in years past, when net income and return on assets were the measures by which a firm's managers were judged. In those bygone days, management focused on effective stewardship; the relevant benchmarks were competitors in the same industry. Today, however, shareholders-from individual investors to giant pension funds-are increasingly judging each company against all others.... This requires a fundamental change in management behavior and perspective. ${ }^{271}$

Similarly, in evaluating CEO turnover in a sample of large U.S. firms in the 1992 to 2005 period, Kaplan and Minton found that CEO turnover increased in the post-1998 period and that the performance-to-turnover effect strengthened in the later period. ${ }^{272}$ One of the most notable findings of a 2001 study by Huson, Parrino, and Starks of CEO turnover in the 1971-1994 period is that the rate of CEO firings in large firms (both in absolute terms and as a fraction of CEO turnover) was as high (or higher by some measures) in the 1989-1994 period as in the 1983-1988 period, the height of the hostile takeover wave, and much higher than in earlier periods in the evolution of corporate governance. ${ }^{273}$ They also show that for the poorest performing firms, where the likelihood of a CEO firing is highest, industry-adjusted stock returns were a better predictor of a firing than income measures, and that the relevance of this predictor was highest in the 1989-1994 period. ${ }^{274}$ Moreover, it appears that the use of industry-adjusted returns in the Huson et al. study may have masked

corporation's board of directors to situations that may directly affect stockholder value.” 1997 BRT Statement, supra note 259, at 1. The BRT also asserted that "selection and evaluation" of the chief executive officer and his or her team "is probably the most important function of the board," and that this role "includes considering compensation, planning for succession and, when appropriate, replacing the CEO or other members of the top management team.” Id. at 5.

270. Chuck Lucier et al., Booz Allen Hamilton, Why CEO’s Fall: The Causes AND CONSEQUENCES OF TURNOVER AT THE TOP, 3-7 (2002), available at http://extfile.bah.com/livelink/livelink/110173/?func=doc.Fetch\&nodeid=110173.

271. Id. at 9 (emphasis in original).

272. Steven N. Kaplan \& Bernadette A. Minton, How Has CEO Turnover Changed? Increasingly Performance Sensitive Boards and Increasingly Uneasy CEOs (Nat'l Bureau of Econ. Research Working Paper No. W12465, 2006), available at http://ssrn.com/ abstract $=924751$.

273. Mark R. Huson et al., Internal Monitoring Mechanisms and CEO Turnover: A Long-Term Perspective, 56 J. Fin. 2265, 2279-90 (2001).

274. Id. at 2290 tbl.V. 
evidence of a straightforward reliance on shareholder returns by the 1990s board; this becomes apparent from an event study they performed that captures stock returns upon announcement of a CEO firing. For the 1989-1994 period, the average cumulative abnormal return upon such a termination is $4.00 \%$ compared to only $1.75 \%$ for the $1983-1988$ period, ${ }^{275}$ suggesting that firings by the 1990s board were, to a greater degree than previously, guided by the anticipation of an increased stock price. ${ }^{276}$

These trends are consistent with related work by Farrell and Whidbee, whose analysis of CEO turnover in the 1986-1997 period shows that the rate of CEO firings (both in absolute terms and as a fraction of CEO turnover) was higher in the 1995-1997 period than in the preceding 1989-1994 period. ${ }^{277}$ Moreover, they show that a significant predictor of managerial turnover is failure to meet analysts' consensus earnings forecasts, that is, a strongly unexpected negative earnings surprise. ${ }^{278}$ Although they do not map this onto stock price changes, the association between a negative earnings surprise and a stock price decline seems straightforward.

The result of this more demanding standard for CEO performance was, according to the Booz Allen study, to shorten average CEO tenure from 9.5 years (1995) to 7.3 years (2001) and to shorten the average tenure of fired CEOs from 7.0 years (1995) to 4.6 years (2001). ${ }^{279}$

\section{c. Golden parachutes}

The third element of the 1990s board's focus on shareholder value in the market for managerial services was the "golden parachute," a generous severance package that was another alignment mechanism. The typical "chute" provided for a severance of approximately three times salary plus the average bonus of prior years, and, in the case of a change in control transaction, added the accelerated vesting of stock options that had been granted but were not yet

275. Id. at 2295 tbl.VII. The difference between the two periods is statistically significant.

276. In other words, the board has rational expectations about whether a CEO firing will increase the stock price and acts accordingly. For further discussion on stock returns versus earnings as predicting CEO turnover, see Benjamin A. Hermalin \& Michael S. Weisbach, Endogenously Chosen Boards of Directors and Their Monitoring of the CEO, 88 Am. ECON. Rev. 96 (1998). Cf. Dirk Jenter \& Fadi Kanaan, CEO Turnover and Relative Performance Evaluation 18-19 (MIT Sloan Research Paper No. 4594-06, 2006), available at http://ssrn.com/abstract=885531 (evaluating 1995-2001 CEO turnovers and finding that CEOs are more likely to be replaced following poor industry and poor market performance, suggesting that boards incompletely filter out the effects of exogenous factors; average CARs are negative following forced turnover).

277. Kathleen A. Farrell \& David A. Whidbee, Impact of Firm Performance Expectations on CEO Turnover and Replacement Decisions, 36 J. ACCT. \& ECON. 165, 173 tbl.1 (2003).

278. Id. at $166-67,175$.

279. LUCIER ET AL., supra note 270, at 8-9. 
vested. ${ }^{280}$ The severance payments were nice but the option acceleration provisions could make the CEO genuinely rich. The chute could be a seen as compensation for the depreciation in the terminated CEO's human capital in respect of the termination decision. This was a significant consolation prize for the terminated CEO, which presumably reduced resistance, and also made it easier for the board to attract a replacement CEO under similarly unforgiving performance expectations. In the case of an uninvited premium takeover bid, such packages often converted CEOs from opposition to acquiescence. One consequence was that despite the availability for many U.S. firms of the nearly bullet-proof antitakeover defense of a poison pill combined with a classified board, ${ }^{281}$ takeover activity in the United States reached new heights in the 1990s. In particular, in the 1996-2000 period, fewer than 100 (of 40,000 total) acquisitions in the U.S. takeover market were reported as "hostile"; only in thirty-two did managers resist to the point where the target remained independent. $^{282}$

The intensity of takeover activity despite the availability of strong defenses illustrates the power of the shareholder value criterion in the 1990s corporate culture. Boards seemed to welcome, not fight, an appropriately rich bid, and managers went along because of compensation contracts that truly did align their interests with those of the shareholders. The shift in elite managerial opinion during the 1990s in favor of the shareholder value criterion even at the cost of some managerial autonomy had a certain historical contingency and much self-interest, but was real nevertheless.

280. See generally Michael S. Sirkin \& Lawrence Cagney, Executive COMPENSATION § 9 (1998).

281. See supra note 247.

282. Lucian Arye Bebchuk et al., The Powerful Antitakeover Force of Staggered Boards: Theory, Evidence, and Policy, 54 STAN. L. REV. 887 (2002). In this study, of the 100 hostile bids, only thirty-two firms remained independent over the long term, twenty-one of which had "effective staggered boards." Losses to target shareholders from defeated hostile transactions were approximately $\$ 30$ billion if calculated using the figures in the study, id. at 926 tbl.2, 933 fig.4, 935 tbl.3. But, there were over 40,000 acquisition transactions in the period, valued at $\$ 6.4$ trillion; the accrued gains were $\$ 1.9$ trillion. This means that the percentage of defeated transaction was vanishingly small $(0.08 \%)$; those cases account for $1.2 \%$ of the total M\&A activity and $1.5 \%$ of the gains. Moreover, the study presents no evidence of a selection effect of targets based on the availability of a classified board, and the sheer volume of acquisition activity combined with the ubiquity of classified boards (approximately half of public firms) makes a powerful selection effect unlikely. The study's findings in the context of the overall U.S. takeover market demonstrate the limited effect of antitakeover measures in the United States. See Jeffrey N. Gordon, An American Perspective on Anti-Takeover Laws in the EU: A German Example, in REFORMING CoMPANY AND TAKEOVER LAW IN EUROPE (Guido Ferrarini et al. eds., 2004). 


\section{Markets generally}

A final element in the 1990s embrace of shareholder value in contrast to 1950s managerialism is a different conception of the role of markets. As argued previously, the 1950s tendency was to believe that the firm could create and manage markets. By contrast, as evidenced by the growth of disaggregated, networked firms, the 1990s tendency was to use market signals to manage the firm. ${ }^{283}$ Independently, the collapse of the Soviet Union was taken to demonstrate the superiority of market-based governance over centralized planning. From a different perspective, one important consequence of the downfall of communist regimes was the elimination of a potential political competitor for the allegiance of workers. If part of the rationale for the 1950s concern for stakeholders rested on the Cold War, that particular ideological competition was over. Capitalism, and capitalism's recourse to markets, was the only game in town. It was simply a lot easier for managers (and others) to ignore some of the adjustment costs associated with market-guided decisionmaking, what might be called the "transition costs of capitalism," in this environment. Managers were able to rest on the normatively attractive claim that shareholder wealth maximization would in fact maximize social surplus, and so workers in general, even if not a particular group of laid off workers, would be better off. ${ }^{284}$

\section{E. The 2000s: New Roles for Independent Directors and New Standards of Director Independence}

\section{Introduction}

The collapse of Enron, WorldCom, and similar but less catastrophic disclosure failures vividly demonstrated weaknesses in the board governance system produced by the 1990s and pointed the way towards new roles for

283. Naomi R. Lamoreaux et al., Beyond Markets and Hierarchies: Toward a New Synthesis of American Business History, Am. Hist. Rev., Apr. 2003, at 404; William Savitt, A New New Look at Corporate Opportunities (Columbia Law Sch. Ctr. for Law \& Econ. Studies, Working Paper No. 235, 2003), available at http://ssrn.com/abstract $=446960$ (reviewing network industries literature); $c f$. Charles F. Sabel \& Jonathan Zeitlin, Neither Modularity nor Relational Contracting: Inter-Firm Collaboration in the New Economy, 5 ENTERPRISE \& SOC'Y 388 (2004) (describing richer forms of collaboration relying on pragmatist theories of knowledge).

284. There are, of course, critical ways of reading the history. Englander and Kaufman, for example, claim that during the 1990s U.S. managerial capitalism shifted from a "technocratic" form concerned with balancing stakeholder interests to a "proprietary" form in which managers competed in tournaments whose ultimate payoff was a disproportionate share of the firm's wealth and society's wealth. Ernie Englander \& Allen Kaufman, The End of Managerial Ideology: From Corporate Social Responsibility to Corporate Social Indifference, 5 ENTERPRISE \& SOC’Y 404 (2004). 
independent directors and standards of independence. ${ }^{285}$ The 1990s system depended on an independent board's contracting with managers using stock market-based measures of managerial success to determine both compensation and tenure. Appropriate operation of the contracts critically depended upon the quality of the firm's disclosure, since otherwise stock prices would not reflect managerial performance. Yet the managers whose compensation and tenure depended on these stock prices were principally responsible for producing the disclosure on which the contracts relied. Boards had simply failed to appreciate and protect against some of the moral hazard problems that stock-based compensation created, in particular, the special temptations to misreport financial results. ${ }^{286}$ The principal objective of the Sarbanes-Oxley Act of 2002, then, was the protection of the integrity of financial disclosure, both through extensive new regulation of accountants and through new disclosure monitoring responsibilities imposed on directors.

\section{Contractual vulnerabilities}

As noted above, the favored form of performance-based compensation in the 1990s was a large load of plain-vanilla stock options. The payoff from a stock option is asymmetric by design: unlimited upside potential, limited downside exposure. This is particularly the case where options are doled out so freely as to be almost free (i.e., no foregone cash compensation) and where underwater options may be repriced. The payoff from stock is itself asymmetric (and hence has been likened to an option), but stock has value (is "in the money") at any positive price, whereas an option that expires below its exercise price ("out of the money") is valueless. Thus, a too-rich stock option package can create a distinctive set of moral hazard problems. ${ }^{287}$ First, and most obviously, stock options can be redistributive. Exercised stock options increase the number of shares outstanding and thus dilute the existing holders' claim on the firm's cash flows. Stock options grants are redistributive if the value of the options is greater than the executive services received; large or "mega” grants of nonexpensed options seem likely candidates.

Second, more seriously, managers with large option grants may be strongly tempted to manipulate financial results, most typically through the overstatement of earnings. Several recent studies find that the probability of

285. Some of this Part draws from Gordon, supra note 82, and Gordon, supra note 83.

286. The emerging evidence of questionable practices in the timing of stock option grants suggests that board members were insufficiently attentive to this temptation as well. See, e.g., Randall A. Heron \& Erik Lie, Does Backdating Explain the Stock Price Pattern Around Executive Stock Options Grants?, 83 J. Fin. Econ. 271 (2007). This could be because of their own stock-based compensation. See Bebchuk et al., supra note 81 (finding favorable timing in option grants to outside directors that is inconsistent with sheer chance).

287. For further exploration of problems associated with the use of options, see Gordon, supra note 83. 
accounting fraud, though small, nevertheless increases with the amount of stock-based compensation, and increases as well with the fraction of total compensation that is stock-based. ${ }^{288}$ The source of the temptation becomes apparent in comparing two forms of incentive compensation, cash bonuses and stock options. Bonus payments will typically increase linearly with earnings but the value of stock options can increase (decrease) exponentially because of the double effect that earnings changes have on stock prices. Earnings changes affect prices both through operation of the price/earnings ratio and through the impact on the market's perception of the company's growth rate and thus the p/e ratio itself. ${ }^{289}$

Nevertheless, on the "chickens come home to roost" theory, ${ }^{290}$ it might appear that achieving financial results through manipulation would be irrational, and thus not so serious a threat. The firm's true condition will eventually come to light, the stock price will fall, and the executives' options may well become worthless. (This is not to mention the potential legal sanctions for fraud.) But such reasoning does not appreciate the benefits and risks from the executive's perspective. Before the revelation, the executive may have become rich through prior option exercises (and a prompt sale of the underlying stock, or a "cashless exercise") at the inflated price; the firm might reprice the worthless options or grant some new ones; the necessary earnings restatement may be buried with some other extraordinary adjustment; or a positive shift in market conditions may overtake the earlier misrepresentation. Certainly under prevailing practices in the 1990s, even a significant restatement was unlikely to trigger an SEC enforcement action, much less a criminal prosecution, and any civil litigation would be resolved well short of a finding of fraud, meaning that either the D\&O insurer or the company (but not executive) will fund any settlement. Thus, as compensation came increasingly to consist of

288. These studies are canvassed in Jensen \& Murphy, supra note 265. See also David J. Denis et al., Is There a Dark Side to Incentive Compensation? (Mar. 2005) (unpublished manuscript), available at http://ssrn.com/abstract=695583.

289. To take a simple example: Assume in year $\mathrm{t}=1 \mathrm{a}$ company earns $\$ 5$ per share and its stock trades with a $\mathrm{p} / \mathrm{e}$ ratio of 10 , so the stock price is $\$ 50$ a share. In year $t=2$ the company earns an additional $\$ 1$ per share, that is, earnings increase by $20 \%$. Assume there are 1 million shares outstanding and that the CEO has 50,000 expiring options with a \$50 exercise price. A cash bonus will amount to some fraction of the total additional earnings, but obviously would never exceed $\$ 1$ million. By contrast, through operation of the p/e ratio alone, the additional $\$ 1$ of earnings produces a $\$ 10$ per share increase. But if this $20 \%$ yearover-year improvement changes the market's perception of the company's growth rate and thus the p/e ratio, it will generate a much greater increase in the stock price. So, for example, if the p/e ratio increases from 10 to 15 , the price will increase not from $\$ 50$ to $\$ 60$, but from $\$ 50$ to $\$ 90$. The effect on CEO wealth is amazing: an increase of $\$ 2$ million, double the total amount of additional earnings. The calculation, via the Black-Scholes method, becomes more complex for options of greater duration, but the point remains. Thus, it is not surprising that earnings manipulations to generate and sustain a higher p/e ratio is more tempting as the level of options increases.

290. Cf. In re Pure Resources, Inc., Shareholders Litig., 808 A.2d. 421, 446 (Del. Ch. 2002) (explaining the "goose and gander rule"). 
high-powered incentives like stock options and as the absolute level of potential stock option payout over a short period of time increased, management's temptations grew. This is the source of the most difficult moral hazard problem associated with the 1990s governance pattern. ${ }^{291}$

In short, managements had high-powered incentives with foreseeable moral hazard problems. The necessary institutional complement was highpowered monitoring by the board. This was missing at many firms.

\section{Contracting failures}

The problems with stock option packages arose not only from the asymmetric payoff structure but also from their very size. The temptation to manipulate earnings was presumably increasing with the size of the payoff. Certainly the risks of shareholder dilution were increasing with the size of the option package. Observers have debated whether boards pervasively failed in their obligation to establish arm's length bargaining with the senior managers. ${ }^{292}$ Regardless of the board's independence in other matters, it seems clear that independence was undercut in the setting of compensation. In some cases the CEO or other members of the management team participated in compensation committee activities. This participation included retaining the same consultants hired by senior managers for larger and more lucrative human resource assignments for the firm. Often nominally independent directors were not actually independent in this domain, either because of a pecuniary relationship with the firm that management could control or because of the "backscratch" problem that arose because of director interlocks. The conception of director "independence" had been insufficiently rigorous to manage the powerful managerial self-interest that was unleashed by the writing of increasingly rich executive compensation agreements.

\section{Director independence reconsidered}

The principle institutional failure that produced Enron and its ilk was the failure of the gatekeepers, especially the accountants, not the insufficiency of director independence. ${ }^{293}$ Yet boards had not performed well either, having

291. Another moral hazard problem arguably arose from the board's focus on stock price performance in its termination decision, see supra Part III.D.3.b, which added to management's temptation to manipulate results.

292. Compare BEBCHUK \& FRIED, supra note 109 (explaining high compensation levels as managerial rent-seeking), with Jeffrey N. Gordon, Executive Compensation: If There's a Problem, What's the Remedy? The Case for Compensation Discussion and Analysis, 30 J. CORP. L. 675 (2005) (arguing that many other factors also important, perhaps more so in most cases).

293. See John C. Coffee, Jr., Gatekeepers: The Professions and Corporate Governance (2006); John C. Coffee, Jr., Gatekeeper Failure and Reform: The Challenge of Fashioning Relevant Reforms, 84 B.U. L. REV. 301 (2004). 
failed to address management's undercutting of gatekeeper integrity. There certainly was a substantive case for enhancing the independence-in-fact of directors, particularly if the managerial agency problem was to be addressed through incentive-based compensation and termination contracts rather than through control markers. As post-Enron reform pressure mounted, managerial elites moved to ramp up board independence as an alternative to more intrusive regulation, in this way protecting managerial autonomy to the extent possible in the changed environment. The New York Stock Exchange impaneled a corporate governance task force to restore public confidence and to show that private regulation could address the governance failures that Enron revealed without need for federal legislation. This was the origin of the tightened director independence requirements added to the NYSE's listing standards, including compensation committees staffed solely by these more stringently qualified independents. ${ }^{294}$ The Business Roundtable emphasized the importance of independent directors and the importance of the board's role in "[f]ocusing on the integrity and clarity of the corporation's financial statements and financial reporting.,295 Just as it seemed that managerial elites were going to succeed in defeating legislative action, the WorldCom scandal broke in spring 2002, which raised the saliency of corporate governance problems and created unstoppable momentum for the legislation that became Sarbanes Oxley. Ironically, then, some of the emphasis on director independence in the postEnron environment is the byproduct of a failed effort to offer up stronger board monitoring to forestall legislative change. Most recently, managerial elites have invoked the independent board, especially its nominating committee, as part of the effort to beat back the SEC's proposal for limited shareholders access to the management proxy statement to make director nominations.

The post-Enron reforms lay the groundwork for a revised model of corporate governance. The model operates at many different levels. It ratchets up the liability for primary wrong-doers, particularly corporate officers. It imposes new duties, new liabilities, and a new regulatory structure on certain gatekeepers, accountants in particular but also lawyers and, in a fashion, securities analysts. The effect of the reforms on the board's role is to make the role of the independent director more important than ever. Both the federal securities law and the stock exchange listing requirements imposed more rigorous standards of director independence. ${ }^{296}$ Boards, particularly the audit committee, are given a specific mandate to supervise the firm's relationship with the accountants and thus to oversee the corporation's internal financial controls and financial disclosure. ${ }^{297}$ Boards are more likely to hear about their lawyers' concerns that the firm's managers are not in compliance with the

294. See supra notes 50-52, 107 and accompanying text.

295. Bus. RoundtABLE, supra note 102, at 5 (emphasis omitted).

296. See supra notes 50-53, 107-09 and accompanying text.

297. Id. 
federal securities laws or even state fiduciary duty. ${ }^{298}$ Directors, then, will have a particularized monitoring role, what might be called "controls monitoring," in addition to "performance monitoring."

\section{F. Summary}

This brief and partial history aims to give context to the secular trend observed in Part I: a dramatic shift in the composition of the board away from insiders and toward independents. The shift towards independent directors is reflected not just in the numbers or percentages but also in the likelihood of independence in fact. What the history also reveals is that the rise of the independent board is associated with an increasing orientation of the corporate purpose toward shareholder wealth maximization and with a growing role for the board in mediating between the firm and the stock market. The legal resolution of the hostile takeover battles of the 1980s was, first, that the firm is not always up for sale (meaning the shareholders don't decide), but second, that the ultimate decisionmaker was not to be the highly conflicted managers but the somewhat conflicted board. The growing focus on director independence was stimulated by the desire to enhance the credibility of such decisionmaking to the relevant audiences, particularly increasingly active institutional investors. But the board's mediation between the firm and market was not limited to accepting or refusing a hostile takeover bid. Rather, in acceptance of the claim that the managerial goal was to maximize shareholder value, boards increasingly employed stock prices in compensation arrangements and in making termination decisions. Managers were thus exposed to "soft-form" stock market pressure rather than the "hard form" pressure of hostile bids. What was insufficiently recognized in this transformation is the importance of a new role for the board: the monitoring of financial controls and disclosure. Stock market prices were not spontaneous creations; they could be manipulated and inflated by self-interested managerial action, and the new approach that incorporated stock prices into both compensation and termination created powerful incentives for such behavior. This would place new and greater demands on the monitoring capacity of boards and would lead in turn to more rigorous standards of director independence.

298. See Sarbanes-Oxley Act of 2002 § 307, 15 U.S.C. § 78j-1 (2007) (as implemented by 17 C.F.R. pt. 205 (adopted by Implemenation of Standards of Professional Conduct for Attorney, Securities Exchange Act Rel. No. 47,276, 79 SEC Docket 1351 (Jan. 29, 2003))). 


\section{THE INCREASING INFORMATIVENESS OF STOCK PRICES, 1950-2005}

\section{A. Introduction}

This Part argues that the rise of independent directors is partly explained by the increasing informativeness of stock prices over the 1950-2005 period. As more information about the firm is impounded in the stock price, insiders lose a privileged claim of insight about the firm's performance and prospects. More importantly, the nature of performance monitoring changes. As stock prices become more informative, the directors' monitoring role increasingly consists of using stock price metrics to measure the firm's performance over time and against relevant intra-industry comparisons. This is not to deny the existence of private information nor the value of the directors' critical perspective on stock market measures, particularly over short time frames. Nevertheless, in light of the positional conflicts that undermine insiders' capacity to monitor senior management, the increasing informativeness of stock prices changes the comparative advantage of independent directors. The independents' information debilities decrease and their monitoring advantages become more apparent.

An informal model may help to clarify the point. Assume that directors' monitoring capabilities are a function of two variables, information about the firm (which includes information about expected future results as well as current results) and independence from the senior management team. Start with a polar case, a private firm, in which there is no public disclosure and thus no stock market prices that impound disclosure. The tradeoff between firmspecific information and independence may favor a predominantly inside board, even for monitoring purposes. Independent directors (which excludes significant shareholders or their agents or other affiliated directors) have insufficient incentives to become informed and get no help from public investors' assessment of value. Uninformed independence has limited value; hence we should expect to see more insiders on the board. Assume instead that the firm is public. As the market becomes increasingly well informed about the firm's performance and prospects, the directors get increasing help in understanding the firm from competitive stock price formation (and softer forms of market feedback, such as analysts' reports). The independents' information deficit is ameliorated. All other things equal, from the monitoring perspective, board composition will shift in favor of the independents. In other words, holding other things constant, the percentage of insiders (independents) should be decreasing (increasing) in the degree of stock price informativeness.

There is a second explanatory element that followed from the increasing informativeness of stock prices over the period. Managers increasingly turned to stock market signals for strategic guidance, rather than relying solely on internally-generated information. This too undermined the case for insiders on the board. The 1950s firm embodied a strong belief in the power of 
bureaucratic rationality to accurately sense and determine the appropriate strategy, indeed, of bureaucratic rationality's power to shape the market environment in which the firm operated. The success of this managerial form was celebrated by Alfred Chandler's Strategy and Structure, which emphasized the importance of management's information gathering, forecasting, planning, and resource allocation. ${ }^{299}$ Indeed, as firms undertook more complex tasks of planning and organization, many companies apparently replaced outside directors with insiders, precisely because of their deep knowledge. ${ }^{300}$ Moreover, information was power. As Chandler observed: since senior managers "provided the board and the stockholders and, of course, any government or regulatory agency with whatever detailed data about the company these groups might want, their actions were controlled only negatively by their legal superiors."301

But it was actually the 1960s conglomerate firm that reflected the high water mark of the managerial belief in internally generated information as the ultimate strategic tool. Managers took the multidivisional or "M-form" structure that had evolved in the early 20th century to manage the large firm that focused on a unitary, if complex, business ${ }^{302}$ and extended it to the management of diverse business units that had no necessary relation to one another. The conglomerate was premised on the belief that the headquarters team could outperform external capital markets in monitoring the managers of diverse business units and in making appropriate resource allocations among them. ${ }^{303}$ The failure of several conglomerates in the 1970s, the evidence of the general inefficiency of the conglomerate form, ${ }^{304}$ and the successful leveraged bust-up of many conglomerates in the 1980s led to an emphasis on "focus" in drawing the boundaries of the firm. ${ }^{305}$ One important implication of this shift

299. Alfred D. Chandler, JR., Strategy and Structure: Chapters IN THE HISTORY OF THE INDUSTRIAL ENTERPRISE 99, 149, 152, 282, 291-92, 396 (1962) [hereinafter Chandler, StRAtegy and StRucture]. Chandler sounds similar themes about the rise of "managerial capitalism" (the "visible hand"): although the market "remained the generator of demands for good and services ... modern business enterprise took over the functions of coordinating flows of goods through existing processes of production and distribution, and of allocating funds and personnel for future production and distribution.” ALFRED D. Chandler, JR., The Visible Hand: The Managerial Revolution in American Business 1 (1977).

300. See Peter F. Drucker, The New Society: The Anatomy of Industrial Order 223 (rev. ed. 1993).

301. ChandLer, StRATEgy AND StRUCtURE, supra note 299, at 314.

302. The M-form structure replaced "the centralized, functionally departmentalized or unitary (U-form) structure” that proved a much less efficient way to manage large enterprise. Oliver E. Williamson, The Modern Corporation: Origins, Evolution, Attributes, 19 J. Econ. LITERATURE 1537, 1555 (1981). Identifying and describing this shift was Chandler's signal achievement in STRATEgY AND STRUCTURE, supra note 299.

303. Williamson, supra note 302, at 1557-60.

304. See GILSON \& BLACK, supra note 248, at 336-46 (summarizing evidence).

305. See, e.g., Philip G. Berger \& Eli Ofek, Bustup Takeovers of Value-Destroying Diversified Firms, 51 J. FIN. 1175 (1996); Sanjai Bhagat et al., Hostile Takeovers in the 
was heightened appreciation of stock market prices as a guide to capital and other resource allocation as against internally generated information in the complex firm. The insiders' firm-bound information did not necessarily give them superior insight into how best to monitor managers or allocate capital. An independent director looking to increasingly informative stock prices might have insight unbiased by the internal perspective. ${ }^{306}$

There are many reasons to believe that stock prices have became more informative over the 1950-2005 period. First, important empirical work by financial economists shows that individual stock price movements over the period became increasingly decoupled from overall market movements, meaning that firm-specific factors became increasingly influential. This greater firm-specific return variation is best explained, in the United States, in terms of increasingly informative stock prices. Second, firms in fact have been disclosing increasingly more information, as measured by a simple survey of public filings over the period. Third, the SEC's disclosure regime has promoted more disclosure, and more useful disclosure, through: (i) mandatory disclosure of information that firms were unlikely to disclose voluntarily, (ii) permissive disclosure of information (like projections) that the SEC had previously prohibited, and (iii) prescriptive standardization that has made comparisons easier. Fourth, the pronouncements of the Financial Accounting Standards Board (and its predecessors) have led to the disclosure of more value relevant information and also aided uniformity. Fifth, a grab bag of other factors also have made stock prices more informative, including an increase in the number of analysts and other investment professionals, the rise of mutual funds and other institutional investors with sufficient scale to undertake securities research, and information technology and information dissemination mechanisms that lower the cost of securities research.

\section{B. Market-Level Empirical Evidence on Stock Price Informativeness: Synchronicity and $R^{2}$}

Important recent work by financial economists provides evidence that U.S. stock prices have become more informative over a long time frame, particularly since 1950. Using a 1926-1995 time series, Morck et al. show that the movement of U.S. stock prices has become less "synchronous" over time, meaning that a decreasing fraction of stocks move up or down together. ${ }^{307}$ (See

1980s: The Return to Corporate Specialization, 1990 BROOKINGS PAPERS ON ECON. ACTIVITY: MicROECONOMICS 1.

306. Thus, the increasing informativeness of stock prices helps address the "monitoring vs. managing" tradeoffs that some thought were inherent in the independent board. See, e.g., Jill E. Fisch, Taking Boards Seriously, 19 CARDOZO L. REV. 265 (1997).

307. See Randall Morck et al., The Information Content of Stock Markets: Why Do Emerging Markets Have Synchronous Stock Price Movements?, 58 J. FIN. ECON. 215 (2000). The article's principal thrust is a cross-country study of cross-sectional variation in 


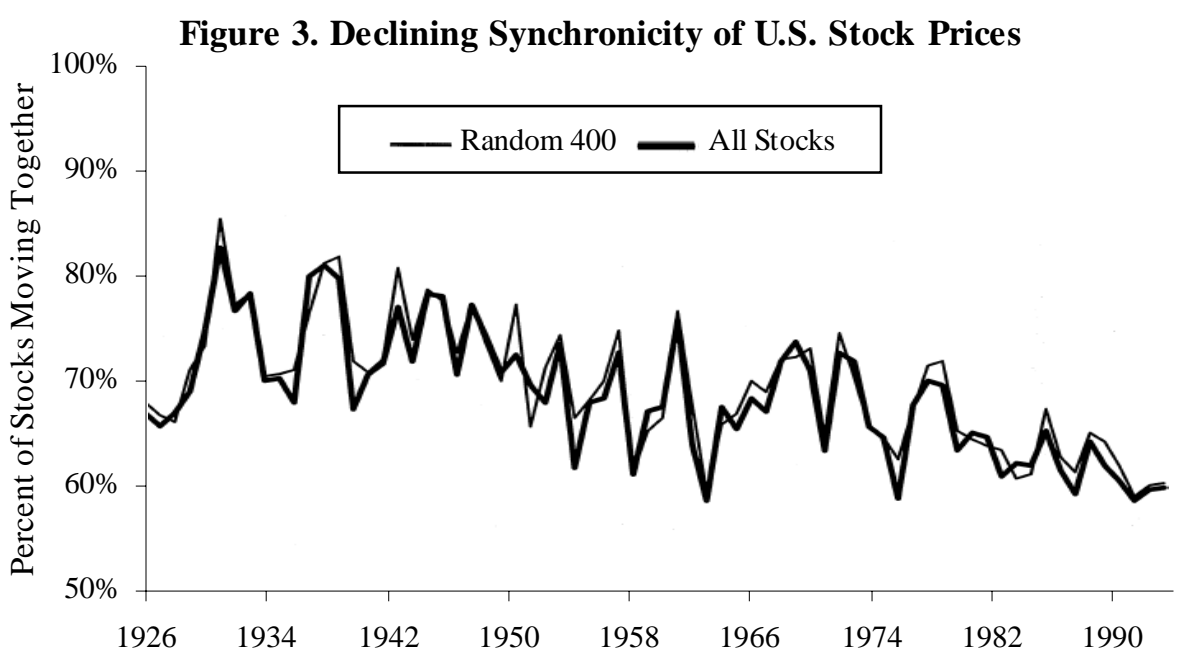

Source: Morck et al., supra note 307, at 221 fig.2, described as "[t]he fraction of stocks moving together each month from 1926 to 1995 using all available U.S. stocks and using a portfolio of 400 stocks randomly chosen each month. Returns include dividend income and are from Center for Research in Securities Prices.”

Figure 3.) This pattern gains importance in light of cross-country evidence that shows that synchronicity is inversely related to capital market development. Emerging market economies exhibit a high degree of synchronous stock price movement; developed market economies exhibit a low degree. Moreover, although U.S. stock price volatility has remained roughly constant over the period, an increasing percentage of the returns on individual stocks is attributable to firm-specific factors, rather than market factors. This effect is captured by a variable called $\mathrm{R}^{2}$, which measures the extent to which the market model accounts for the variation in stock returns. As with synchronicity, $\mathrm{R}^{2}$ has declined over the 1926-1995 period, particularly since $19500^{308}$ (See Figure 4 below.)

Morck et al. attribute the declines in synchronicity and $\mathrm{R}^{2}$ to an increasing payoff to arbitrageurs from a focus on firm-specific factors rather than marketwide factors, including speculation and fads. Looked at from the cross-country perspective, the value of a firm-specific focus is principally a function of the levels of property right protection and investor protection. For the United

synchronous stock price movements, which shows much greater synchronicity in emerging markets than in developed markets. The article also explores U.S. time-series data, noting the sharp changes over time. See also Merritt B. Fox et al., Law, Share Price Accuracy, and Economic Performance: The New Evidence, 102 Mich. L. REV. 331 (2003).

308. For confirmation of the decline of $\mathrm{R}^{2}$ in the United States in the post-1960 period, see Cambell et al., Have Individual Stocks Become More Volatile? An Empirical Exploration of Idiosyncratic Risk, 56 J. FIN. 1, 23-25 (2001). 
States, where these institutions have been relatively stable, particularly in the post-1950 period, the increasing information content of prices seems likely to account for the decline in synchronicity and $R^{2}$. Durnev et al. support this argument with evidence that firms with lower $\mathrm{R}^{2}$ exhibit a higher correlation between current stock returns and future earnings. ${ }^{309}$ This suggests that $\mathrm{R}^{2}$ reflects the extent to which information about future returns is impounded into the stock price. Thus, the post-1950 decline in average $\mathrm{R}^{2}$ for U.S. stocks can be taken as a measure of the increasing informativeness of stock prices during the period. ${ }^{310}$

\section{Firm-Level Empirical Evidence of More Disclosure by Firms}

The stock market evidence that increasingly more firm-specific information has been impounded into stock prices is supported by additional evidence that examines the disclosure practices of firms. We conducted a simple survey to assess the amount of public firm disclosure over the 19502004 period. $^{311}$ The general strategy was to look at the key annual disclosure document required by the SEC, the Form $10-\mathrm{K}$, for a sample of large public firms over the period. The Form 10-K includes a narrative description of the firm, its businesses, and its competitive situation, as well as detailed financial information. A major driver, if not the principal driver, of the growth in Form $10-\mathrm{K}$ disclosure has been changing SEC requirements and new accounting pronouncements. ${ }^{312}$ Important information that firms "voluntarily" disclosed would ordinarily be subject to subsequent inclusion in the Form 10-K, so the Form $10-\mathrm{K}$ should be a good general disclosure indicator.

We measured the Form 10-K in different categories: the number of total pages, the number of pages of financial information, the number of notes to the

309. Artyom Durnev et al., Does Greater Firm-Specific Return Variation Mean More or Less Informed Stock Pricing?, 41. J. AcCT. RES. 797 (2003) (covering 1983-1995 period); see also Qi Chen et al., Price Informativeness and Investment Sensitivity to Stock Price, REV. FIN. STUD. 619 (2007) (showing that the $\mathrm{R}^{2}$ measure of private information impounded in stock prices predicts sensitivity of corporate investment to stock price); Art Durnev et al., Value-Enhancing Capital Budgeting and Firm-Specific Stock Return Variation, 59 J. Fin. 65 (2004) (marginal changes in Tobin's $q$ performance measure are positively correlated with increased informativeness as measured by $\mathrm{R}^{2}$ ). But see Kewei Hou et al., $R^{2}$ and Price Inefficiency (Fisher Coll. of Bus., Working Paper No. 2006-03-007, 2006), available at http://ssrn.com/abstract=954559 (finding a negative relationship between $\mathrm{R}^{2}$ and overreaction-driven price momentum, suggesting a connection between $\mathrm{R}^{2}$ and inefficiency, and citing to other working papers skeptical of a positive relationship to efficiency).

310. Other empirical work also supports the disclosure/informativeness link by showing that stock returns of firms with higher Association for Investment Management Research-Financial Analysts Federation corporate disclosure ratings are better predictors of future earnings changes. See, e.g., David S. Gelb \& Paul Zarowin, Corporate Disclosure Policy and the Informativeness of Stock Prices, 7 REV. ACCT. STUD. 33 (2002).

311. Benjamin Whetsell bore the laboring oar in this project.

312. See infra text accompanying notes 315-78. 
Figure 4. Declining Fraction of U.S. Stock Return Variation Explained by the Market

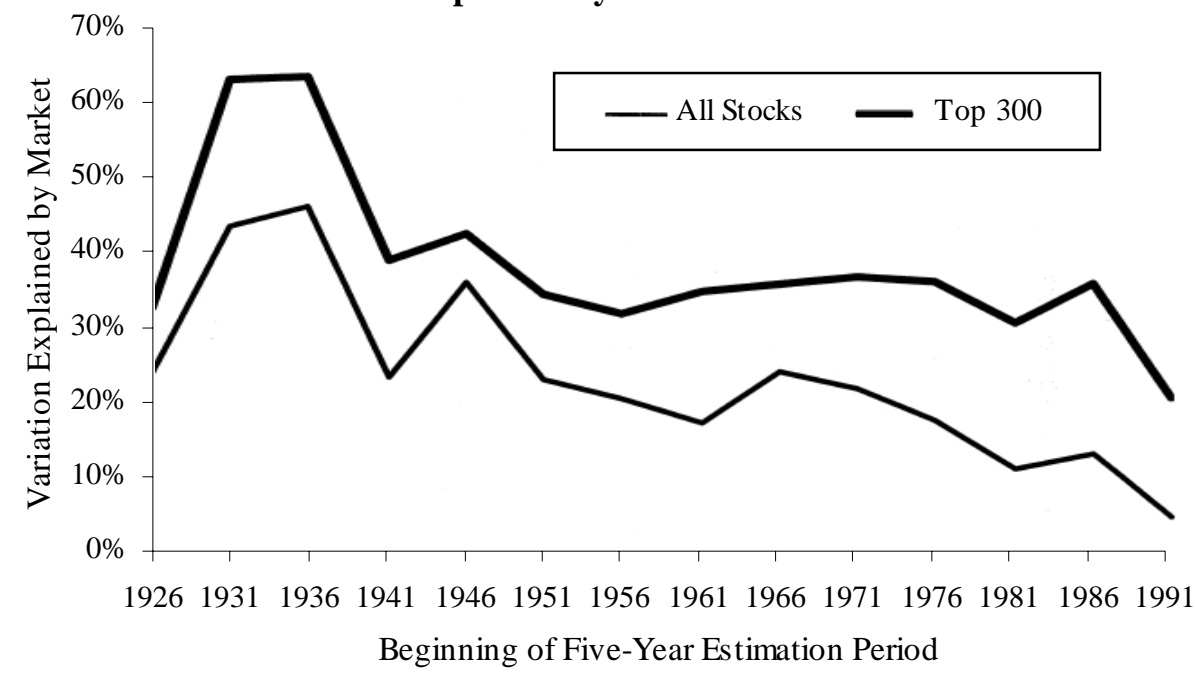

Source: Morck et al., supra note 307, at 222 fig.3, described as "[t]he declining fraction of U.S. stock return variation explained by the value-weighed market index estimated by running a simple market model regression of using monthly returns including dividend income for sequential disjoint four year periods from 1926 to 1995, using all available U.S. stocks and a portfolio of 400 stocks randomly chosen each period. Returns and indexes include dividend income and are from the Center for Research in Securities Prices.”

financial statements, and the number of pages of notes. Our sample was drawn from the seventy-seven firms that have appeared in the Fortune 500 since its inception in 1955, and the page counts were based on Form 10-Ks on digitized microcards from Thompson ONE Banker, microfiche, and film microcards. Where only annual reports were available (typically the case before 1969, when regulatory change more clearly distinguished the Form 10-K from the annual report), we subtracted pages that, on the basis of section headings and content, were not Form 10-K material (picture spreads, etc.). Occasionally the Form 10$\mathrm{K}$ included detailed information about employee retirement plans, specifically, informational pamphlets for employees, that would be of dubious value to an investor. We omitted these from the page count. More generally, Form 10-Ks identify key contracts (such as loan agreements) that are occasionally attached but more often are "made available" elsewhere. Such exhibits were not included in the tally. Nor did we count the pages of material about the issuer's officers and directors, board structure, and executive compensation that is typically incorporated by reference into a Form 10-K from the issuer's Form $14 \mathrm{~A}$, the proxy statement. Mandatory proxy statement disclosure has certainly increased during the period, so non-inclusion of this material will understate the level of additional disclosure. 
Figure 5. Increased Disclosure, 1950-2005

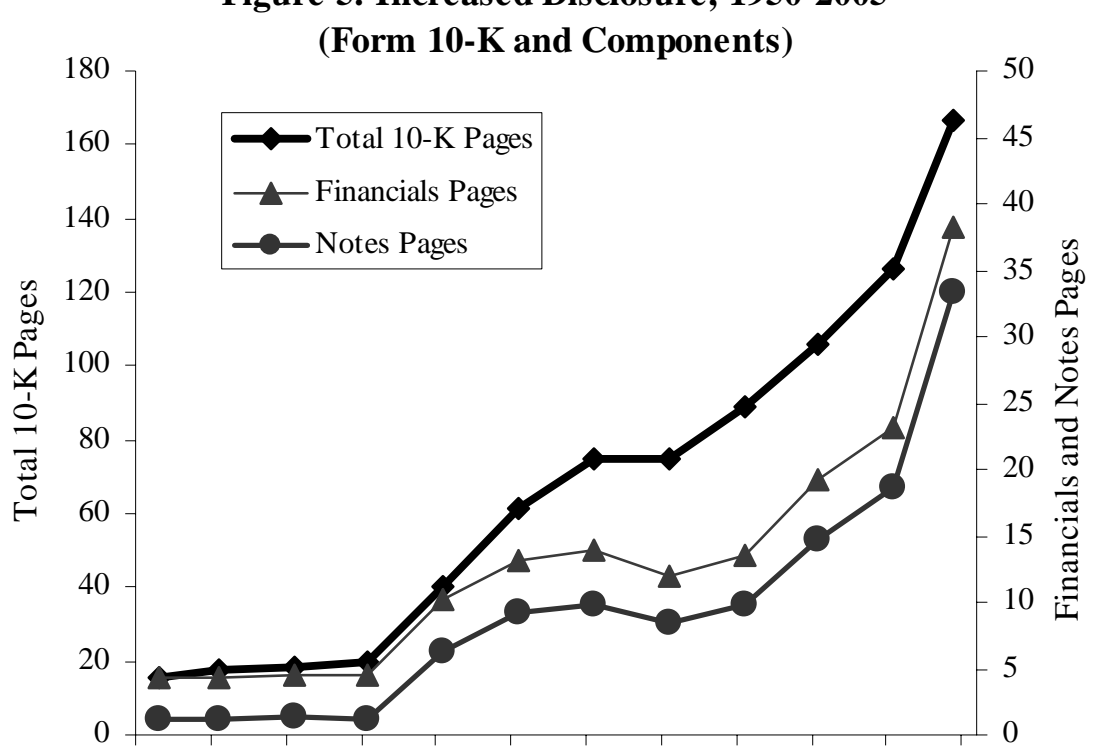

195019551960196519701975198019851990199520002005

Source: Average page counts (means) of Form 10-Ks and components compiled every five years from a sample $(n=20)$ of Fortune 500 firms that continuously made public disclosure over the period (universe=77). Data appear in Appendix Table 2. Right y-axis measures increased page numbers of financial statements and footnotes to financials; left y-axis measures increased page numbers of entire Form 10-K.

As Appendix Table 2 and Figure 5 illustrate, the number of pages in all categories substantially increased over the period. The average number of pages in a Form 10-K was approximately sixteen in 1950, twenty in 1965, but then grew rapidly thereafter, from forty in 1970 to 125 in 2000, and, in the post-Sarbanes-Oxley world, 165 in 2004. The financials (including notes) grew from four pages in 1950 and 1960 to ten pages in 1970, twenty-three in 2000, and thirty-eight in 2004. The number of notes to the financial statements grew in parallel, from five notes in 1950 to nineteen notes in 2000 and 2004. Most of the increase in the length of the financials was from the addition of notes.

This reflects an enormous increase in firm-specific disclosure over the period. The 1970s marked a period of especially rapid growth in these disclosure categories. As described above, this is the decade of corporate governance upheaval, and, in terms of board composition, the point at which the number of insiders began to decline and independents to increase. 


\section{Additional Disclosure Because of SEC Regulation}

Changes in SEC disclosure regulation have led to considerably more disclosure, and more useful disclosure, over the 1950-2005 period and have thus enhanced the informativeness of stock prices. SEC regulatory action has affected disclosure in three ways. First, some actions have been disclosure forcing, leading to more information disclosure than would have voluntarily occurred. Second, some actions have been disclosure permitting, eliminating barriers to disclosures that firms would make voluntarily. Third, some actions have been disclosure standardizing, making firm-specific disclosure more readily comparable across firms.

The claim that SEC action enhanced the level of disclosure over the period depends only in part on the case for mandatory disclosure, since some of the most important interventions over the period were first, the elimination of barriers to forward-looking disclosure that firms wanted to make and investors wanted to have and, second, the establishment of disclosure conventions that made disclosure more useful. Without engaging the mandatory disclosure debate in full force, ${ }^{313}$ it seems straightforward that an effective regulator could mandate disclosure of information that firms would not voluntarily disclose and that would otherwise not be available to the market. First, because disclosure affects shareholder monitoring, managers would exercise discretion to produce suboptimal disclosure from the shareholder point of view. Suboptimal disclosure is one element of managerial agency costs, and good mandatory disclosure policy can help overcome it. Second, because disclosure often reveals competitively sensitive information, optimal disclosure from a firmspecific perspective is suboptimal from a social perspective. Shareholders of any particular firm face a classic prisoner's dilemma: full disclosure by other firms enables better managerial monitoring because of comparative performance benchmarks, yet each firm's locally rational course is not to disclose. Mandatory disclosure overcomes this collective action problem and produces particular gains when shareholders are diversified. Third, the alternative way of delivering information to the market, insider trading, is a noisy, awkward vehicle for disclosure, and in any event has probably declined in importance since the SEC began its enforcement efforts in the 1960s. ${ }^{314}$

313. This is ably canvassed in Fox et al., supra note 307, at 335-44. See also Allen Ferrell, The Case for Mandatory Disclosure in Securities Regulation Around the World (John M. Olin Ctr. for Law, Econ., and Bus., Harvard Law Sch., Paper No. 492, 2004), available at http://ssrn.com/abstract $=631221$.

314. See, e.g., SEC v. Tex. Gulf Sulphur Co., 401 F.2d 833 (2d Cir. 1968), aff'g in part and rev'g in part 258 F. Supp. 262 (S.D.N.Y. 1966), cert. denied 394 U.S. 976 (1969); Cady, Roberts \& Co., 40 S.E.C. 907 (1961). 


\section{Disclosure forcing}

Section 13(a) of the 1934 Securities Exchange Act requires public companies listed on an exchange to file annual and quarterly reports as prescribed by the SEC. The practice of sending annual reports to security holders apparently derived from early state corporate and tax law requirements for the annual filing of financial statements and for the issuer's distribution of such reports, sometimes only upon request, to all security holders or a certain proportion of security holders. ${ }^{315}$ The New York Stock Exchange independently required the distribution of annual and quarterly reports for listed companies in $1933 .{ }^{316}$ In 1942, the SEC required that an annual report "containing such fi[n]ancial statements for the last fiscal year as will, in the opinion of the management, adequately reflect the position and operations of the issuer" be sent to security holders in connection with a management proxy solicitation for the annual election of directors. ${ }^{317}$ Professor Loss's 1961 edition of Securities Regulation suggests, through an absence of discussion, that the SEC during the 1950s did not attempt to deepen disclosure. ${ }^{318}$ To the contrary, the SEC backed down in 1953 on a proposal to require quarterly reports, and, in its subsequent adoption of a semiannual reporting requirement, permitted, in effect, informal financial statements. ${ }^{319}$ The SEC appeared to be deferring to managers, who, among other reasons, objected to possible competitive disadvantage from disclosure, despite the protestations of securities analysts, "who reported through their national organization that their efforts to obtain voluntary agreement from companies to provide quarterly sales reports had been discouraging." ${ }^{320}$ Managerial deference seemed to be a theme of the Eisenhower-era SEC, reflected in a narrowing of shareholder access to the management proxy, as well as budgetary cutbacks for the agency. ${ }^{321}$

315. See 2 Louis Loss, Securities Regulation 825 (2d ed. 1961). But cf. David F. Hawkins, The Development of Modern Financial Reporting Practices Among American Manufacturing Corporations, 37 Bus. HIST. REV. 135, 142-43 (1963) (showing only some states required distribution).

316. 2 Loss, surpra note 315, at 804-08.

317. Exchange Act Release No. 3347, 1942 WL 34864 (Dec. 18, 1942).

318. See 2 Loss, supra note 315, at 809-57.

319. Id. at $815-16$.

320. Id. at 815; see also Hawkins, supra note 315, at 140-42, 160-61 (describing the persistence of competitive concerns about disclosure). The major effort of the reformers was aimed at broadening the coverage of Securities Exchange Act disclosure to include public companies that were not listed on an exchange. See, e.g., Joel Seligman, The Transformation of Wall Street 310-14 (1982); Philip A. Loomis, Jr., The Securities Exchange Act of 1934 and the Investment Advisors Act of 1940, 28 GEO. WASH. L. REV. 214, 220, 226-28 (1959). These efforts culminated in the Securities Acts Amendments of 1964, Pub. L. No. 88-467, 78 Stat. 565.

321. See Seligman, supra note 320, at 265-73. 
a. Disclosure integration.

In the ensuing decades, however, beginning around 1970, there were many new disclosure requirements. ${ }^{322}$ It is sufficient for illustrative purposes here to sketch some of the most important, including the development of segment reporting beginning in 1969 and the development of "management discussion and analysis" (MD\&A) beginning in 1972. But a pervasive source of disclosure deepening over the period was the effort to "integrate" the disclosure requirements of the 1933 and 1934 securities acts. As famously argued by Milton H. Cohen in 1966, the happenstance enactment sequence of the 1933 Act (addressing public offerings) followed by the 1934 Act (addressing secondary market activity) distorted the disclosure system. ${ }^{323}$ In light of the small number of public offerings and the massively greater volume of share turnover in secondary market trading, "integration" of the two schemes should proceed by building on the continuous disclosure pattern of the 1934 Act, he argued. Thus, a seasoned issuer should market securities through a 1933 Act registration process that relied substantially on information already disclosed to the market through the 1934 Act filings. "Yet, as a broad generalization, the disclosure process under the 1934 Act (apart from proxy solicitations) appears never to have been taken quite as seriously as under the 1933 Act, very likely because of differences in the attendant liabilities and sanctions and in Commission procedures." ${ }^{\text {„324 }}$

The SEC came to embrace the project of disclosure integration wholeheartedly. ${ }^{325}$ It saw that robust continuous disclosure was an essential component, and thus at every turn it sought to ratchet up the 1934 Act periodic filings to the same depth and currency as would be expected of a 1933 Act registration statement. Notably, in 1977 the SEC adopted Regulation S-K, which prescribes the substance and form of non-financial disclosure for both

322. See generally 2 Louis Loss \& Joel Seligman, Securities Regulation 599-751 (3d ed. rev. 1999).

323. Milton H. Cohen, “Truth in Securities” Revisited, 79 HARV. L. REv. 1340, 134142 (1966). For a dissenting view, which argues that Congress would not have contemplated 1933 Act disclosure requirements incorporated into 1934 Act filings, see Paul G. Mahoney, Mandatory Disclosure as a Solution to Agency Problems, 62 U. CHI. L. REV. 1047, 1081-88 (1995) (arguing that 1934 Act disclosure was aimed at controlling self-dealing and other duty of loyalty problems, not enhancing stock price accuracy).

324. Cohen, supra note 323, at 1361.

325. The key moments were the so-called "Wheat Report" in 1969, SEC. \& EXCH. COMM'N, Disclosure to INVESTORS: A REAPPRAisAl OF FEDERAL ADMiNistrative PoliCiES UNDER THE '33 AND '34 ACTS (1969), which was named after the director of the small group which prepared the report, Commissioner Francis M. Wheat, and the "Sommer Report" in 1977, H. Comm. ON InTERstate \& Foreign COMmerce, 95Th Cong., 1st Sess., Report of the Advisory CommitTeE on Corporate Disclosure to the SeCurities AND EXCHANGe Commission (Comm. Print 1977) [hereinafter Sommer Report], which was named after the committee's chairman, former Commissioner A.A. Sommer, Jr. See 2 Loss \& Seligman, supra note 322, at 599-624. 
1933 Act and 1934 Act filings. ${ }^{326}$ Similarly, through Regulation S-X and various accounting pronouncements, the SEC has developed a common standard for the substance and form of financial disclosure for filings under both acts whose consequence is much deeper disclosure for 1934 Act filings than previously. ${ }^{327}$

\section{b. Segment reporting}

In 1969, the SEC began to require firms to disclose "industry segment" data, meaning disclosure that broke out revenues and income for separate lines of business. ${ }^{328}$ The impetus for this change was the conglomerate merger movement of the 1960s, in which firms expanded through unrelated diversification. Under the prevailing consolidation rules, the operating and financial results of substantial enterprises could disappear into undifferentiated totals. This created problems for antitrust enforcement as well as shareholder monitoring. Although some firms voluntarily disclosed line-of-business results, the overwhelming majority did not. ${ }^{329}$ The SEC's initial approach was to require segment disclosure for a "product-line" that accounted for at least ten percent of the firm's total revenues or pre-tax income, but giving management considerable discretion to define product lines and address issues like common costs and intra-company transfers. Although this initial formulation of segment reporting was sharply criticized for the discretion given managers (by the FTC, for example), contemporary empirical studies found that the additional disclosure still enabled investors to better anticipate future earnings and improved the accuracy of analysts' earnings forecasts. ${ }^{330}$

By 1977, the SEC's Advisory Committee on Corporate Disclosure weighed in on the question, reporting, among other things, "the almost universal

326. Industry Segment Reporting, Securities Act Release No. 5893, Exchange Act Release No. 14,306, Investment Company Act Release No. 10,070, 42 Fed. Reg. 65,554 (Dec. 30, 1977); see 2 Loss \& SELIGMAN, supra note 322, at 627-724.

327. See 2 Loss \& Seligman, supra note 322, at 724-32.

328. This is account is based principally on SELIGMAN, supra note 320, at 433-38, and 2 Loss \& SELIGMAN, supra note 322, at 654-64.

329. See Daniel W. Collins, SEC Product-Line Reporting and Market Efficiency, 2 J. Fin. ECON. 125, 126 \& nn.2-3 (1975). Of 600 firms surveyed, twenty-one had some segment reporting in 1967, ninety-three in 1968, and 194 in 1969 (the last year in the shadow of impending regulatory change). The survey did not test the voluntary disclosure against the ultimate regulatory standard.

330. See id.; Daniel W. Collins, SEC Line-of-Business Reporting and Earnings Forecasts, 4 J. Bus. REs. 117 (1976). Compare Bertrand Horwitz \& Richard Kolodny, Line of Business Reporting: A Rejoinder, 9 BELL J. ECON. 659 (1978) (viewing the effect negatively), with Richard R. Simonds \& Daniel W. Collins, Line of Business Reporting and Security Prices: An Analysis of an SEC Disclosure Rule, 9 BELL J. ECON. 646 (1978) (rebutting Horwitz and Kolodny's argument). Among other things, Collins's 1975 study showed that differences in stock price movements between firms that did and did not voluntarily disclose segment data disappeared after 1970. See Collins, supra note 329. 
dissatisfaction analysts express with the level of segmentation currently provided by the registrants in SEC disclosure documents." 331 Acting quickly, the SEC simply embraced the recently (1976) promulgated accounting standard that imposed a more exacting test based on "whether products and services are related (and, therefore, should be grouped into a single industry segment) or unrelated (and, therefore, should be separated into two or more industry segments) . . ..”332 Although the standard admitted of certain management discretion, it added to investors' capacity to see the different elements of the business.

Twenty years later, in 1997, the Financial Accounting Standards Board revisited the question with a new accounting standard that framed segment disclosure in terms of the enterprise's internal organization. Among other features, a "segment" is a component of the enterprise "[w]hose operating results are regularly reviewed by the enterprise's chief operating decisionmaker to make decisions about resources to be allocated to the segment and assess its performance"; in effect, a profit center approach. ${ }^{333}$ The goal was to move away from the subjectivity of the industry approach, which had been gamed by some large firms that reported all their activities as occurring in one large industry. In contrast, the internal organization approach was designed to permit financial statement users "to see an enterprise 'through the eyes of management[,]' [which] enhances a user's ability to predict actions or reactions of management that can significantly affect the enterprise's prospects for future cash flows." ${ }^{334}$ The structure of Regulation S-K, which requires reporting in terms of "generally accepted accounting principles," automatically picked up this further elaboration of the segment reporting requirement. ${ }^{335}$ The reformulated segment accounting standard, as incorporated into mandatory disclosure, provided new information to the market and thus made stock prices more informative. ${ }^{336}$ 325).

331. 2 Loss \& SELIGMAN, supra note 322, at 659 (quoting Sommer Report, supra note

332. See Fin. Accounting Standards Bd., Statement of Financial Accounting

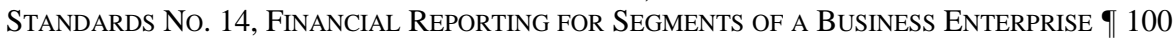
(1976). The standard used a 10\% threshold for revenues, profits (losses), and assets.

333. Fin. Accounting Standards Bd., Statement of Financial Accounting Standards No. 131, Disclosure About Segments of an Enterprise and Related INFORMATION ๆ 10(b) (1997).

334. Id. ๆ 60.

335. Reg. S-K, 17 C.F.R. § 229.101(b) (2007) (Financial Information About Segments). It is also noteworthy that Item 101 also requires financial information about geographic areas, another way to disaggregate overall results into national segments. Id. $\S$ 229.101(d).

336. See Bruce K. Behn et al., The Predictive Ability of Geographic Segment Disclosures by U.S. Companies: SFAS No. 131 vs. SFAS No. 14, 1 J. INT'L ACCT. RES. 31 (2002) (using a sample of 172 of the largest 1000 firms and finding that the new standard led to more informative geographic sales data that increased reliability of forecasting models); Don Herrmann \& Wayne B. Thomas, An Analysis of Segment Disclosures Under SFAS No. 
What bears underscoring about segment reporting, then, is that it makes available to the market information about the separate businesses within the firm that the firm itself has collected for internal management purposes. Seeing the information from management's perspective, investors can better measure the firm's past performance and can better predict the future. This makes stock prices more informative. Moreover, the various regulatory changes in segment reporting over the period made "external" segments (i.e., what is disclosed) more closely reflect the firm's "internal" segments. This increase in "congruency" made the resulting disclosure increasingly reliable throughout the period and thus enhanced informativeness. ${ }^{337}$

\section{c. Management's discussion and analysis}

In 1974, the SEC began to require a so-called "Management's Discussion and Analysis" (MD\&A) to be added to disclosure documents to provide a narrative account of the financial results and, in particular, to provide a managerial perspective on material changes. Intially these changes were to be measured in quantitative terms. ${ }^{338}$ In 1980 , the SEC considerably broadened the MD\&A requirement in response to criticisms of the quantitative test. The new full title is quite descriptive: "Management's Discussion and Analysis of Financial Condition and Results of Operations."339 As the SEC later explained, "MD\&A is intended to give the investor an opportunity to look at the company through the eyes of management by providing both a short and long-term analysis of the business of the company., 340

A major goal of the 1980 reformulation of MD\&A was to advise investors how things might change, not just a retrospective account of why they did. Management was called upon to "identify known trends or uncertainties" that

131 and SFAS No. 14, 14 ACCT. HoRIzONS 287, 287 (2000) (finding that in a sample of 100 of the 250 largest U.S. firms under the new accounting standard, more firms reported segments and reported them in more detail; authors concluded that the change in reporting requirements had a "relatively significant impact on the disclosure of segment information"); Donna L. Street et al., Segment Disclosures Under SFAS No. 131: Has Business Segment Reporting Improved?, 14 ACCT. HoRIzONS 259 (2000) (finding that in a sample of 160 of the 1000 largest firms, fewer firms claimed to operate in one line-of-business, more segments were reported, and more detail was included in segment reports).

337. Laureen A. Maines et al., Implications of Proposed Segment Reporting Standards for Financial Analysts’ Investment Judgments, 35 J. AcCT. RES. 1 (Supp. 1997).

338. The quantitative threshold was non-trivial: a $10 \%$ change in revenues or expenses from the prior period coupled with a $2 \%$ change in net income. See Securities Act Release No. 5520, Exchange Act Release No. 10,961, 39 Fed. Reg. 31,894 (Sept. 3, 1974). This discussion follows 2 Loss \& SELIGMAN, supra note 322, at 688-98, and Fox et al., supra note 307, at 369-70.

339. See Reg. S-K, 17 C.F.R. § 229.303 (2007).

340. Concept Release on Management's Discussion and Analysis of Financial Condition and Operations, Securities Act Release No 6711, Exchange Act Release No. 24,356, 38 SEC Docket 145 (Apr. 17, 1987). 
could have material positive or negative results for any of earnings, liquidity or capital resources. In particular, MD\&A was to "focus specifically on material events and uncertainties known to management that would cause reported financial information not to be necessarily indicative of future operating results or of future financial condition." ${ }^{341}$ Although historically the SEC had been quite skeptical of forward-looking information, ${ }^{342}$ MD\&A disclosure required firms to project "known trends or uncertainties" onto the company's future prospects. ${ }^{343}$

Although the MD\&A formulation remained substantially unchanged in the 1980-2000 period, the SEC prodded firms at various times to provide richer accounts of prospective developments that could affect future performance. ${ }^{344}$ The Enron shock revealed the way that off-balance sheet and other contingent liabilities could affect future prospects (to put it mildly), and, in 2003 the SEC added substantial new requirements in this area to MD\&A. ${ }^{345}$

The SEC's efforts to promote deeper discussion of the firm's financial statements are reflected in the growth of MD\&A disclosure over the period. As Appendix Table 3 indicates, the average length of MD\&A disclosure in Form $10-K s$ among the sampled firms grew significantly, from two pages (1974, the original requirement) to four pages (1980, expanded version) to six pages (1990) to eleven pages (2000). The effect of the new post-Enron disclosure requirements and the generally heightened demand for a heads-up on risk factors was dramatic: average MD\&A more than doubled to twenty-four pages (2004).

One important question is whether mandatory MD\&A did in fact make stock prices more informative. Conceivably (if improbably) the information had been otherwise communicated to the market through indirect means. Fox et al. test the proposition with an application of the $\mathrm{R}^{2}$ methodology referred to above. In a before-after test of the effects of MD\&A, they find that the new regime leads to earlier disclosure of information with earnings implications, meaning that the $\mathrm{R}^{2}$ for a group of firms expected to be slow disclosers is lower

341. Reg. S-K, 17 C.F.R. § 229.303(a), Instruction 3 (2007).

342. See infra Part IV.D.2.

343. Reg. S-K, 17 C.F.R. § 229.303(a)(3)(ii) (2007).

344. See, e.g., Concept Release on Management's Discussion and Analysis of Financial Condition and Operations, Securities Act Release No. 6711, Exchange Act Release No. 24,356, 38 SEC Docket 145 (Apr. 17, 1987); Management's Discussion and Analysis of Financial Condition and Results of Certain Operations, Securities Act Release No. 6835, Exchange Act Release No. 26,831, Investment Company Act Release No. 16,961, 43 SEC Docket 1330 (May 18, 1989).

345. See Disclosure in Management's Discussion and Analysis About Off-Balance Sheet Arrangements and Aggregate Contractual Obligations, Securities Act Release No. 8182, Exchange Act Release No. 47,264, 79 SEC Docket 1251 (Jan. 28, 2003) (adding Regulation S-K Item 303(a)(4) (“Off-balance sheet arrangements”) and Item 303(a)(5) ("Tabular disclosure of contractual obligations," which focuses on long-term financing contracts). These new MD\&A requirements respond to the mandate in Section 401(a) of the Sarbanes-Oxley Act for enhanced disclosure in this area. Id. 
after the new regulation. ${ }^{346}$ This implies that post-MD\&A, stock price changes derive less from market-wide movement and more from firm-specific factors. Such evidence supports the view that disclosure-forcing regulatory action can and did make stock prices more informative. ${ }^{347}$

\section{Disclosure permitting}

One of the most significant SEC actions with respect to stock price informativeness over the period was to permit the disclosure of "soft" or "forward-looking" information that many firms wanted to disclose (often because of investor and analyst pressure) but were constrained from doing so. ${ }^{348}$ From the 1930 s through 1973, the SEC prohibited the disclosure of earnings projections or other forward-looking information, at one point declaring that projections were per se misleading. ${ }^{349}$ Multiple factors played a role in the SEC's position, including: an investor protection mindset framed in terms of the least sophisticated investor; an intellectual conservatism that mimicked the accountant's traditional reliance on historical information, in which the verifiability of figures trumped the possible utility of projections; and a cross-cutting belief that investors, given the "facts," were as competent as managers to make projections. ${ }^{350}$ An influential 1970 article by Professor Homer Kripke, a one-time SEC staffer, rebutted these various concerns: managements, which were already generating such projections in internal decisionmaking, had immense advantages over investors in such forecasting. The efficient market would protect unsophisticated investors against noncredible projections because of the role of analysts and sophisticated investors

346. See Fox et al., supra note 307, at 370-78 (using the period before implementation of the 1980 changes as the baseline).

347. Another important recent empirical test of mandatory disclosure's role in stock price informativeness is provided by Allen Ferrell, Mandated Disclosure and Stock Returns: Evidence from the Over-the-Counter Market (John M. Olin Ctr. for Law, Econ., and Bus., Harvard Law Sch., Discussion Paper No. 453, 2003), available at http://ssrn.com/ abstract $=500123$. See also Michael Greenstone et al., Mandated Disclosure, Stock Returns, and the 1964 Securities Acts Amendments, 121 Q.J. ECON. 399 (2006).

348. In general, this account is based on John C. CoffeE, JR. \& Joel Seligman, Securities Regulation: CASES AND MAterials 231-33 (9th ed. 2003); 2 Loss \& SELIGMAN, supra note 322, at 629-48; Mahoney, supra note 323, at 1105-07. See also Garry F. Goldring, Note, Mandatory Disclosure of Corporate Projections and the Goals of Securities Regulation, 81 Colum. L. Rev. 1525 (1981); Kimberly Till, Note, The SEC Safe Harbor for Forecasts-A Step in the Right Direction?, 1980 DuKE L.J. 607.

349. See Securities Act Release No. 5699, Exchange Act Release No. 12,371, 9 SEC Docket 472 (Apr. 23, 1976) (withdrawing earlier statement relating to projections of future economic performance).

350. For a sense of the zeitgeist of the SEC staff, see Harry Heller, Disclosure Requirements Under Federal Securities Regulation, 16 Bus. LAW. 300, 307 (1961). 
in price formation. In any event, knowingly false projections were subject to SEC anti-fraud rules. ${ }^{351}$

In 1973, the SEC announced its intention to permit but not require disclosure of projections that met various criteria for reliability and general dissemination. ${ }^{352}$ Therein lay the rub, because firms and their advisers were quite concerned about liability for projections that subsequently turned out otherwise. For almost five years and several iterations of proposals, the SEC struggled to produce a satisfactory "safe harbor rule," eventually succeeding in $1979 .{ }^{353}$ Rule 175 provided that a "forward looking statement" is not a "fraudulent statement . . . unless it is shown that such statement was made or reaffirmed without a reasonable basis or was disclosed other than in good faith." "Forward looking statement” was defined broadly to include projections of revenues and various financial items as well as earnings, and statements of management's "plans and objective for future operations."354

Notwithstanding the safe harbor protections and generally favorable judicial interpretations, ${ }^{355}$ firms and their advisors became leery in light of attorney-driven shareholder plaintiff litigation in the 1990s and succeeded in including in the Private Securities Litigation Reform Act of 1995 ("PLSRA") statutory protection for forward looking information. ${ }^{356}$ New section 27A of the 1933 Securities Act and new section 21E of the 1934 Act provide a safe harbor for a forward-looking statement that is identified as such and "is accompanied by meaningful cautionary statements identifying important factors that could cause actual results to differ materially from those in the forward-looking statement." 357

There is some uncertainty about firms' willingness to make forwardlooking statements outside the mandatory provisions of MD\&A. ${ }^{358}$ For

351. Homer Kripke, The SEC, the Accountants, Some Myths and Some Realities, 45 N.Y.U. L. REV. 1151, 1197-99 (1970).

352. See Securities Act Release No. 5362, Exchange Act Release No. 9984, 1973 WL 149257 (Feb. 2, 1973) (describing prior history and intention to change in light of strong consensus reflected in public hearings and comments).

353. See Securities Act Release No. 6084, Exchange Act Release No. 15,944, 1979 WL 181199 (June 25, 1979) (adopting rule 175, 17 C.F.R § 230.175).

354. The parallel 1934 Act rule was Rule 3b-6.

355. See Coffee \& SEligman, supra note 348, at 232-33.

356. Private Securities Litigation Reform Act of 1995, Pub. L. No. 104-67, § 102, 109 Stat. 737, 749 (amending Securities Act of 1933 § 27A, 15 U.S.C. § 77z-2 (1994); Securities Exchange Act of 1934 § 21E, 15 U.S.C. § 78u-5 (1994)).

357. Securities Act of $1933 \S 27 A(c)(1)(A)(i), 15$ U.S.C. § 77z-2(c)(1)(A)(i) (2007); Securities Exchange Act of 1934 § 21E(c)(1)(A)(i), 15 U.S.C. § 78u-5(c)(1)(A)(i) (2007). The statutory safe harbor essentially brigades Rule 175 with the "bespeaks caution" approach of courts in construing the safe harbor in suits alleging securities fraud.

358. Compare Marilyn F. Johnson et al., The Impact of Securities Litigation Reform on the Disclosure of Forward-Looking Information by High Technology Firms, 39 J. AcCT. RES. 297, 306-07 (2001) (before PSLRA, only 44\% of sample of high tech firms made voluntary forward-looking disclosure; 50\% made such disclosure after PSLRA), with David 
example, some evidence suggests that as many as half of the firms in the hightech area, where the prediction of future trends is particularly important, voluntarily provide forward-looking information. ${ }^{359}$ But many practitioners believe that making projections entails unacceptable legal risk, given possible new duties to update a projection once made. ${ }^{360}$ The PSLRA may have encouraged more firms to disclose projections and other forward-looking information. ${ }^{361}$ In any event, disclosure-permitting regulation has made firms freer to provide forward-looking information across a broad domain of the firm's activity, which will make stock prices more informative.

\section{Disclosure standardizing}

Apart from the effect on the volume of disclosure from mandatory rules, SEC regulation played an important role in standardizing how disclosure was made. This too made stock prices more informative. Conceivably pressure from investors and analysts would have led firms to make more extensive disclosure over the period. Such voluntary disclosure would have itself made stock prices more informative. But SEC standardization made disclosure more valuable by reducing the information processing costs for analysts and investors of firmspecific information. Moreover, standardization made inter-firm comparisons easier as well. The consequence was information that was more quickly and completely impounded in stock prices.

\section{E. Additional Disclosure Because of Accounting Pronouncements and Changes}

Although the debates about the connection between mandatory disclosure and stock price informativeness have focused on SEC action, another important source of disclosure regulation has been the standard setting bodies of the accounting profession, the Financial Accounting Standards Board ("FASB") and its predecessors. ${ }^{362}$ We have already seen the interaction of accounting

M. Levine \& Adam C. Pritchard, The Securities Litigation Uniform Standards Act of 1998: The Sun Sets on California's Blue Sky Laws, 54 Bus. LAw. 1, 43 \& n.219 (1998) (citing trade association survey that found $17 \%$ of firms made voluntary forward-looking statements pre-PSLRA).

359. See Johnson et al., supra note 358, at 306-07.

360. See, e.g., Harvey L. Pitt \& Matt T. Morley, Through A Glass Starkly: A Practical Guide for Management's Forward-Looking Disclosures, INSIGHTS, June 1993, at 3; see also Backman v. Polaroid Corp., 910 F.2d 10, 17 (1st Cir. 1990); In re Phillips Petroleum Sec. Litig., 881 F.2d 1236, 1245 (3d Cir. 1989).

361. See Johnson et al., supra note 358, at 323 (finding evidence of "a significant postAct increase in both the frequency of firms issuing forecasts and the mean number of forecasts issued ... primarily attributable to managers issuing more long horizon forecasts of good news and short horizon forecasts of bad news”). But see Levine \& Pritchard, supra note 358 , at $46-48$ (finding at best only a small change in frequency of voluntary forwardlooking statements).

362. For accounts of this succession and why FASB's predecessors were deemed 
standards with SEC disclosure requirements in the case of segment reporting. In the first instance, the SEC promoted segment reporting and the accounting standard setters followed; subsequently, FASB tightened the standard and the SEC followed. In many other cases, however, the accounting standard setters were at the leading edge, in effect mandating additional disclosure with the adoption of new accounting standards. The dissolution of the Accounting Principles Board (APB) and its replacement by FASB in 1973 had two important consequences: first, an increase in the output of accounting standards; second, enhanced authoritativeness of the announced standard and less tolerance for deviations. These developments led to more disclosure and also greater standardization of existing and new disclosure requirements. In both respects, new accounting standards during the period enhanced the informativeness of stock prices.

This is not the place to canvass the myriad accounting standards changes over a fifty year period, but there are several examples that demonstrate the importance of new accounting standards as expanding the scope of mandatory disclosure and enhancing stock price informativeness. Four seem particularly noteworthy: first, APB No. 22, Disclosure of Accounting Policies, adopted in 1972; second, SFAS No. 52, Foreign Currency Translation, 1982; third, SFAS No. 95, Statement of Cash Flows, 1987; and fourth, SFAS No. 106, Employers' Accounting for Post-Retirement Benefits Other than Pensions, 1990.

\section{APB No. 22, Disclosure of Accounting Policies (1972)}

APB Opinion No. 22 mandates that "a description of all significant accounting policies of the reporting entity should be included as an integral part of the financial statements."363 Frequently, accounting permits alternative presentations for a particular transaction or account. The opinion requires the firm to state which convention it is following, which avoids confusion in cases where alternatives exist and enhances comparability of data across firms. At least one contemporary study demonstrates the value of the opinion. In a before-after survey of 120 firms, Rao showed that before the adoption of APB No. 22, approximately $75 \%$ of firms disclosed common accounting policies, such as the conventions they followed for depreciation and amortization. After adoption, 97\% did. ${ }^{364}$ The opinion seems to have made disclosure more informative by reducing accounting confusion.

inadequate, see GILSON \& BLACK, supra note 248, at 578-586; 2 LOSS \& SELIGMAN, supra note 322, at 733-51. On the SEC decision to privatize the setting of accounting standards despite its undoubted power to set them, see COFFEE \& SELIGMAN, supra note 348, at 67 n.1.

Professor Lawrence A. Cunningham was particularly helpful in identifying important accounting standards adopted over the period.

363. Accounting Principles Bd., Opinion No. 22, Disclosure of Accounting PRINCIPLES \ 8 (1972).

364. Kailis J. Rao, An Evaluation and Empirical Study of the Disclosure of Accounting 


\section{SFAS No. 52, Foreign Currency Translation (1982)}

SFAS No. 52 addressed some of the failings of a predecessor accounting standard, SFAS No. 8 (1975), which was a first attempt to address systematically the accounting problems that arose in foreign operations. Unfortunately, SFAS No. 8 did not take a functional approach, meaning that "firms were compelled to report foreign currency gains and losses that bore little correspondence to the economic effects that they were actually experiencing." 365 SFAS No. 52 remedied this and provided better disclosure by requiring firms to measure the results of foreign operations in the foreign country's "functional currency," typically (but not always) the local currency. The translation technique of SFAS No. 8 had, in effect, required the U.S. dollar as the functional currency for all countries. Various contemporary studies suggest that the change enriched the information environment. ${ }^{366}$

\section{SFAS No. 95, Statement of Cash Flows (1987)}

SFAS No. 95 responded to a change in valuation methodology associated with the leveraged buyouts of the 1980s, namely, a focus on cash flow as opposed to accounting earnings as a critical measure of enterprise value, on the view that cash flow was less distorted by accounting conventions. Investors and other users of financial statements wanted better and more standardized measures of cash flow. SFAS No. 95, which required cash flow reporting, replaced APB Opinion No. 19, Reporting Changes in Financial Position, 1971, which had required instead a "change in financial position" under a formula that could be confused with a cash flow measure. ${ }^{367}$

The informativeness of earnings and cash flow has been a major topic in the accounting literature, which investigates the information content ("value relevancy") of a profitability indicator by measuring its association with returns. Earnings are demonstrably a primary indicator; whether cash flow

Policies in Published Financial Statements, 30 J. Fin. 1160, 1160 (1975).

365. Lawrence Revsine, The Rationale Underlying the Functional Currency Choice, 59 ACCT. ReV. 505, 505 (1984).

366. See, e.g., Billy S. Soo \& Lisa Gilbert Soo, Accounting for the Multinational Firm: Is the Translation Process Valued by the Stock Market?, 69 AсcT. ReV. 617 (1994) (examining market incorporated foreign translation gain and loss information reported in stockholders' equity under SFAS 52 when valuing equity securities); David A. Ziebart \& David H. Kim, An Examination of the Market Reactions Associated with SFAS No. 8 and SFAS No. 52, 62 ACCT. REV. 343 (1987) (showing event studies found positive market response upon adoption of SFAS No. 52, but negative response upon adoption of SFAS No. 8 and interim FASB decisions postponing final action).

367. APB Opinion No. 19 was an apparently unsuccessful attempt to improve on a 1963 predecessor, APB Opinion No. 3, The Statement of Source and Application of Funds. See Earl A. Spiller \& Robert L. Virgil, Effectiveness of APB Opinion No. 19 in Improving Funds Reporting, 12 J. AсCт. REs. 112 (1974) (presenting a before-after study of 143 firms and concluding that the new opinion did not substantially improve on APB Opinion No. 3). 
disclosure provided additional information was an open question. ${ }^{368}$ Before SFAS No. 95, most studies reported mixed results. But after SFAS No. 95, the results of cash flow studies sharply changed; there appears to be no doubt that cash flow disclosure as required by SFAS No. 95 enhances stock price informativeness. ${ }^{369}$ Cash flows are particularly informative when the firm reports outlier earnings (meaning out of line with prior years and thus not likely to persist), ${ }^{370}$ for firms that are cash-dependent because of high leverage or shorter operating cycles, ${ }^{371}$ and for firms where earnings management ${ }^{372}$ or fraud $^{373}$ is a risk.

\section{SFAS No. 106, Employers' Accounting for Post-Retirement Benefits Other than Pensions (1990)}

Before SFAS No. 106, employers accounted for post-retirement benefits on a cash basis. An actual payout produced an expense, meaning "pay as you go." SFAS No. 106 requires firms to account for post-retirement benefits on an accrual basis, meaning expensed over the life of an employment contract, not on a cash basis. For a young employee hired today, a firm must accruemeaning take as a charge to earnings - an actuarially determined amount reflective of future post-retirement benefits, even though there is no current cash payment. (SFAS No. 106 also mandates extensive disclosure about pension plan funding and payment projections.) The accounting standard requires companies to account for distant post-retirement obligations (like retiree health care benefits) that in many cases were grossly under-funded, ${ }^{374}$

368. See generally Ashiq Ali, The Incremental Information Content of Earnings, Working Capital from Operations, and Cash Flows, 32 J. ACCT. REs. 61 (1994).

369. See, e.g., C.S. Agnes Cheng et al., Earnings Permanence and the Incremental Information Content of Cash Flows from Operations, 34 J. ACCT. REs. 173 (1996).

370. C.S. Agnes Cheng \& Simon S.M. Yang, The Incremental Information Content of Earnings and Cash Flows from Operations Affected by Their Extremity, 30 J. Bus FiN. \& АсCT. 73 (2003) (finding that cash flow disclosure has mixed impact on firm valuation, with greatest impact when earnings are high and cash flows are moderate).

371. Mark DeFond \& Mingyi Hung, An Empirical Analysis of Analysts' Cash Flow Forecasts (Univ. S. Cal. Leventhal Sch. of Accounting Working Paper, 2001), available at http://ssrn.com/abstract=265773.

372. Paul M. Healy \& James M. Wahlen, A Review of the Earnings Management Literature and Its Implications for Standard Setting, 13 ACCT. HORIzONS 365 (1999).

373. Thomas A. Lee et al., The Difference Between Earnings and Operating Cash Flow as an Indicator of Financial Reporting Fraud, 16 CONTEMP. ACCT. REs. 749 (1999).

374. Eli Amir, The Market Valuation of Accounting Information: The Case of Postretirement Benefits Other than Pensions, 68 ACCT. REV. 703 (1993). 
made perhaps cavalierly without full appreciation of the ultimate liability, ${ }^{375}$ and which were poorly disclosed to investors. ${ }^{376}$

There appears to be general agreement that this post-retirement benefit disclosure mandated by the new accounting standard added to the informational landscape and led to more fine-grained evaluation by investors. ${ }^{377}$ It certainly had a powerful effect on observed behavior by firms, triggering wide-scale cutbacks in post-retirement health benefits in anticipation of the 1993 effective date. ${ }^{378}$ Presumably managers believed that shareholders would take account of the earnings impact of a non-cash accrual, reflecting, as it did, a genuine future liability.

In sum, what these examples show is that throughout the 1950-2004 period, particularly in the post-1970 period, the FASB's accounting standard setting process has added to the informativeness of stock prices by requiring more disclosure and by limiting the variations in the presentation of similar information.

\section{F. Other Factors Enhancing the Informativeness of Stock Prices}

Several other additional factors also have made stock prices more informative over the period, including an increase in the number of analysts and other investment professionals, the rise of mutual funds and other institutional investors with sufficient scale to undertake securities research, and information technology and information dissemination mechanisms that lower the cost of securities research. For example, membership in the Financial Analysts Federation, the national association of securities analysts, grew from approximately 2400 in 1950 to approximately 11,750 in $1967 .{ }^{379}$ By 2000, the successor organization, the CFA Institute, ${ }^{380}$ had approximately 38,500 North American members (45,750 worldwide), ${ }^{381}$ and in 2005 , more than 70,000

375. Fin. Accounting Standards Bd., Statement of Financial Accounting StANDARDS (SFAS) No. 106, EMPlOyERs'ACCOUNTING FOR POSTRETIREMENT BenEFITS OTHER THAN PENSIONS ๆ $124-26$ (1990).

376. Id.

377. See, e.g., Amir, supra note 374. Eli Amir, The Effect of Accounting Aggregation on the Value-Relevance of Financial Disclosures: The Case of SFAS No. 106, 71 ACCT. REV. 573 (1996); Paquita Y. Davis-Friday et al., The Value Relevance of Financial Statement Recognition vs. Disclosure: Evidence from SFAS No. 106, 74 ACCT. REV. 403 (1999).

378. See Jensen \& Murphy, supra note 263.

379. 2 Loss \& SELIGMAN, supra note 322, at 609 (citing 1969 Wheat Report).

380. The CFA Institute is the new name of the Association for Investment Management and Research, which was created in the 1990 merger of the Financial Analysts Federation and the Institute of Chartered Financial Analysts. See CFA Inst., History of CFA Institute, http://www.cfainstitute.org/aboutus/overview/history.html.

381. See Ass'n for Investment Mgmt. \& Res., 2002 Annual Report: Placing INVESTORS FIRST 40 (2002), available at http://www.cfainstitute.org/aboutus/reports/pdf/ ar2002.pdf. 
members worldwide. ${ }^{382}$ There are simply many more people devoting their careers to assessing firm valuations.

This rise in the number of security analysts is linked on the demand side to the increasing stake of financial intermediaries that invest in sufficient scale to make economical use of securities research. The value of institutional ownership increased dramatically during the period. As Appendix Table 4 indicates, institutional investors owned domestic equities valued at a mere \$12 billion in 1950 (approximately 9\% of the U.S. domestic equity market capitalization) and only \$56 billion in 1960 (14\%). Over the remainder of the period, institutional investor ownership skyrocketed, both in absolute terms and as a fraction of the market value of U.S. domestic equity. As of 2004, institutions owned $\$ 9.6$ trillion in equity, representing $68 \%$ of the market value of U.S. firms. ${ }^{383}$ With these sums at stake, the competitive focus on firmspecific information has become ever more intense.

The growth and spread of information technology has expanded access to firm-specific data, lowering the cost of securities research and increasing the informativeness of stock prices. Originally SEC documents were made available at the SEC's offices in Washington, and lawyers of a certain vintage can remember a booming trade in services that would physically copy documents using increasingly better copying technology for shipment to users, or, in urgent cases, for reading over the telephone of crucial provisions. Beginning in the mid-1980s, and required in the 1990s, companies made electronic filings with the SEC's EDGAR system (for "Electronic Data Gathering, Analysis, and Retrieval”). ${ }^{384}$ Initially private firms, like Disclosure, Inc., compiled databases of this information for resale, but as the internet became increasingly robust in the 1990s, highly detailed, firm-specific information became available to all at virtually no cost, and the proprietary databases became ever more sophisticated in their flexibility of data presentation and manipulation. The rise of the computer, then the personal computer, drastically reduced the cost of information processing, which fostered cross-sectional and time-series analysis of a firm's performance. ${ }^{385}$ As costs fell, sophisticated information gathering and analysis became increasingly "democratized"; institutional investors were no longer the only ones with these

382. See Ass'n for Investment Mgmt. And Res., 2005 Annual Report: SERVing THE GLOBAL INVESTMENT COMMUNITy 27 (2005), available at http://www.cfainstitute.org/ aboutus/reports/pdf/cfa_ar_final.pdf.

383. Compiled from Federal Reserve System, Flow of Funds, Table L213 (compilation provided by Bogle Financial Markets Research Center, on file with author).

384. Sec. \& Exch. Comm'n, Important Information About EDGAR (Feb. 3, 2005), http://www.sec.gov/edgar/aboutedgar.htm; see Donald C. Langevoort, Information Technology and the Structure of Securities Regulation, 98 HARV. L. REV. 747, 758 n.41 (1985).

385. Langevoort, supra note 384, at 757-59. 
capabilities. All of these factors contributed to the informativeness of stock prices over the period.

\section{CONCLUSION: A NEW CORPORATE GOVERNANCE PARADIGM}

This Article starts with a puzzle. There is a powerful trend in favor of independent directors for public firms in the United States, yet the empirical evidence adduced thus far gives us no convincing explanation. The Article suggests that this trend reflects two interrelated developments in the U.S. political economy. First is the shift to shareholder value as the primary corporate objective; the second is the greater informativeness of stock market prices. The overriding effect is to commit the firm to a shareholder wealthmaximizing strategy as best measured by stock price performance. Stock prices are taken as the measure of most things. In this environment, independent directors are more valuable than insiders. They are less committed to management and its vision. Instead, they look to outside performance signals and are less captured by the internal perspective, which, as stock prices become more informative, becomes less valuable. They can be more readily mobilized by legal standards to help provide the public goods of more accurate disclosure and better compliance with law. In this way, independent directors are an essential part of a new corporate governance paradigm. In the United States, independent directors have become a complementary institution to an economy of firms directed to maximize shareholder value. Thus, the rise of independent directors, a very important change in the political economy landscape, should be evaluated in terms of this overall conception of how to maximize social welfare.

Although this new paradigm is bound up with the use of stock market signals in the monitoring of managers, including the evaluation of management's strategic choices, it also opens up space for a distinctive role for the independent board: deciding when prevailing prices misvalue the firm and its strategies. In light of imperfectly efficient capital markets, such a role may be efficiency-based rather than an ineradicable residue of agency costs. For a particular firm, a disfavored strategy may in fact maximize shareholder value over a reasonable time horizon. If the market got it wrong, rejecting its signals may lead to putting the firm's assets to highest and best use. But the most significant efficiency gains (or losses) are systematic: idiosyncratic decisions of an independent board may keep a particular subsector of the economy from converging too rapidly on today's conventional wisdom.

The board's role in this regard is most vividly expressed in the case of an unwanted takeover bid, which, if the board resists, will ultimately be decided through an election contest rather than an immediate market test, under current Delaware law. Presumably the shareholders who would (almost always) accept a premium tender offer would (almost always) vote for directors who would be receptive to the premium offer. The differences between the two mechanisms 
of acceptance are transaction costs and time. On the imperfectly efficient markets view, this small dose of sand in the gears may give markets the opportunity to test predictions of how to create value before the prescription has been universally applied. Some frictions may be efficient. Note that this element of the new paradigm is not inconsistent with maximizing shareholder value; it merely imagines a somewhat longer horizon for its realization than today's stock price.

One open question is whether the independent board has even this independence from the stock market. Before, barring the arrival of a hostile bidder, the board had substantial insulation from shareholder pressure. The costs of maintaining a proxy contest interacted with the collective action problems of diffuse share ownership to produce this result. After the advent of hostile takeovers, the adoption of the pill reinvigorated the board's importance. Now, however, as institutional ownership approaches $70 \%$ of the market and activist shareholders have learned to coordinate their activities without triggering either the notice obligations of the federal securities laws or the target's poison pill, independent boards have much less space to protect an idiosyncratic strategy. The apogee of a corporate governance paradigm resting on independent directors and the independent board may also mark the moment of its decline. 


\section{APPENDIX}

Table 1. Board Composition, 1950-2004

\begin{tabular}{cccc}
\hline \hline Year & Inside (\%) & Affiliated (\%) & Independent (\%) \\
\hline $1950^{\mathrm{a}}$ & 49 & 26 & 22 \\
$1955^{\mathrm{b}}$ & 47 & 30 & 23 \\
$1960^{\mathrm{b}}$ & 43 & 31 & 24 \\
$1965^{\mathrm{b}}$ & 42 & 33 & 25 \\
$1970^{\mathrm{b}}$ & 41 & 34 & 25 \\
$1970^{\mathrm{c}}$ & 58 & 21 & 21 \\
$1970^{\mathrm{d}}$ & 54 & 26 & 20 \\
$1971^{\mathrm{e}}$ & 49 & 13 & 38 \\
$1975^{\mathrm{f}}$ & 39 & 31 & 30 \\
$1977^{\mathrm{g}}$ & 35 & 29 & 36 \\
$1980^{\mathrm{f}}$ & 33 & 30 & 37 \\
$1980^{\mathrm{d}}$ & 43 & 26 & 31 \\
$1983^{\mathrm{e}}$ & 34 & 12 & 54 \\
$1985^{\mathrm{f}}$ & 30 & 31 & 39 \\
$1990^{\mathrm{h}}$ & 26 & 14 & 60 \\
$1991^{\mathrm{i}}$ & 26 & 14 & 60 \\
$1995^{\mathrm{j}}$ & 21 & 15 & 64 \\
$1997^{\mathrm{k}}$ & 19 & 15 & 66 \\
$2000^{\mathrm{k}}$ & 18 & 15 & 67 \\
$2000^{\mathrm{l}}$ & 16 & 15 & 69 \\
$2003^{\mathrm{m}}$ & 16 & 11 & 73 \\
$2004^{\mathrm{n}}$ & 16 & 11 & 73 \\
$2005^{\mathrm{n}}$ & 15 & 11 & 74 \\
\hline
\end{tabular}

a Lehn et al., supra note 8. The breakdown of outside directors is based on the 1970 breakdown in Baysinger \& Butler, supra note 15 (based on proxy statement analysis of 266 large firms); accord Smith, supra note 10, at 48 (based on estimate of affiliates and independents on "typical" board). The Baysinger and Butler 1970 breakdown, in which approximately $43 \%$ of the outsiders are "independent," is applied to the $1950-1970$ period as a conservative assumption. There is some anecdotal suggestion that genuine independents were even rarer before 1970. See Baysinger \& Butler, supra note 15, at 103 n.2 (citing sources).

b Lehn et al., supra note 8 .

c Smith, supra note 10.

d Baysinger \& Butler, supra note 15, at 113 (reporting the board composition of large public firms in 1970 and 1980, and finding that the boards of 266 firms from Forbes list existed in substantially the same form in both 1970 and 1980).

e Hermalin \& Weisbach, supra note 16, at 593 (reporting the board composition of 288 NYSE-traded firms with available information over the 1971-1983 period).

f Lehn et al., supra note 8 . The breakdown of outside directors is based on SEC STAFF REPORT, supra note 11, which, for 1200 major firms surveyed in 1978-1979, classified $55 \%$ of outside directors as independent.

g SEC STAFF REPORT, supra note 11, at 598 tbl.2 (surveying 1200 major firms drawn from NYSE, Amex, Nasdaq, and OTC, in 1978-1979). 
h Lehn et al., supra note 8. The breakdown of outside directors is based on Bhagat \& Black, supra note 17, at 245 tbl.1, which, for 934 large firms included in the Institutional Shareholder Services database in 1991, classified $81 \%$ of outside directors as independent.

i Bhagat \& Black, supra note 17, at 245 tbl.1 (934 large firms in the Institutional Investor Services database). This is consistent with the multi-year composites of Nikos Vafeas, Board Meeting Frequency and Firm Performance, 53 J. FIn. ECON. 113, 121 tbl.1 (1999) (307 firms in Fortune 500 over 1990-1994 period: 28\% insider, 19\% affiliated, and 53\% independent), and David Yermack, Higher Market Valuation of Companies with a Small Board of Directors, 40 J. FIN. Econ. 185, 191 tbl.1 (1996) (452 Fortune 500 firms over 1984-1991 period: 36\% insider, 10\% affiliated, 54\% independent).

j Lehn et al, supra note 8. The breakdown of outside directors is based on Vidhi Chhaochharia \& Yaniv Grinstein, The Transformation of U.S. Corporate Boards: 19972003, at 36-42 tbls.1-2, panel B (May 2004) (unpublished manuscript), available at http://ssrn.com/abstract=556270 (showing that in 1997, firms in the S\&P 500 classified $81 \%$ of outside directors as independent).

k Chhaochharia \& Grinstein, supra note j, at 36-42 tbls.1-2, panel B. This is consistent with Ivan E. Brick \& N.K. Chidambaran, Board Monitoring and Firm Risk 12, 20 (EFA 2005 Moscow Meetings Paper, July 2005), available at http://ssrn.com/abstract=677123 (approximately 2841 firms in 1997-2001 from IRRC and Corporate Library universe).

1 Lehn et al, supra note 8. The breakdown of outside directors based on Chhaochharia \& Grinstein, supra note j, at 36-42 tbls.1-2, panel B.

m Chhaochharia \& Grinstein, supra note j, at 36-42 tbls.1-2, panel B. Brick \& Chidambaran, supra note $\mathrm{k}$, report the percentage of non-insider directors for 2001 as $82 \%$.

n Investor Responsibility Research Center (now Institutional Shareholder Services), S\&P 500 Corporate Governance Database (accessed through Wharton Research Data Services). 
Table 2. Increases in Disclosure, 1950-2004 (Form 10K and Components)

\begin{tabular}{ccccc}
\hline \hline Date & Total 10-K Pages & Financials Pages & Notes Number & Notes Pages \\
\hline 1951 & 15.71 & 4.41 & 5.2 & 1.2 \\
1955 & 17.37 & 4.26 & 6.22 & 1.26 \\
1960 & 18.37 & 4.47 & 6.68 & 1.34 \\
1965 & 19.42 & 4.47 & 6.89 & 1.26 \\
1970 & 40.56 & 10.17 & 12.67 & 6.22 \\
1975 & 61.53 & 13.16 & 14.47 & 9.26 \\
1980 & 74.7 & 13.95 & 17.2 & 9.85 \\
1985 & 75.15 & 12 & 16.95 & 8.4 \\
1990 & 88.6 & 13.55 & 18.6 & 9.73 \\
1995 & 105.75 & 19.15 & 19.15 & 14.75 \\
2000 & 126.1 & 23.2 & 19.15 & 18.7 \\
2004 & 166.25 & 38.15 & 19.85 & 33.3 \\
\hline
\end{tabular}

Source: Average page counts (means) of Form 10-Ks and components compiled at five-year intervals for a sample $(n=20)$ of Fortune 500 firms that continuously made public disclosure over the period (universe=77). Once the firm is drawn by a random process, its Form 10-Ks are tracked throughout the period. Not every firm has data for every year. "Financials pages" includes footnote pages. Medians were checked as well as means; the results are qualitatively unchanged. There is no adjustment for firm size other than continuous inclusion in the Fortune 500.

Table 3. Increases in Management's Discussion and Analysis, 1974-2004

\begin{tabular}{rllllllll}
\hline \hline & 1974 & 1975 & 1980 & 1985 & 1990 & 1995 & 2000 & 2004 \\
\hline MD\&A Pages & 1.88 & 2.61 & 3.5 & 4.45 & 5.85 & 8.8 & 10.6 & 24.05 \\
\hline Source: Average page counts (means) of Management's Discussion and Analysis compiled \\
at approximately five-year intervals beginning in 1974 for a sample (n=20) of \\
Fortune 500 firms that continuously made public disclosure over the 1955-2004 \\
period (universe=77). Once the firm is drawn by a random process, its MD\&A is \\
tracked throughout the period. Medians were checked as well as means; the results \\
are qualitatively unchanged. There is no adjustment for firm size other than \\
continuous inclusion in the Fortune 500.
\end{tabular}


Table 4. Institutional Ownership of U.S. Public Equities, 1950-2004

\begin{tabular}{ccc}
\hline \hline Year & $\begin{array}{c}\text { Institutional Ownership } \\
\text { (Billions of U.S. Dollars) }\end{array}$ & $\begin{array}{c}\text { Institutional Ownership } \\
\text { (Fraction of U.S. Market Cap) }\end{array}$ \\
\hline 1950 & $\$ 12$ & $9 \%$ \\
1955 & $\$ 30$ & $11 \%$ \\
1960 & $\$ 56$ & $14 \%$ \\
1965 & $\$ 115$ & $16 \%$ \\
1970 & $\$ 266$ & $33 \%$ \\
1975 & $\$ 345$ & $43 \%$ \\
1980 & $\$ 599$ & $42 \%$ \\
1985 & $\$ 1183$ & $55 \%$ \\
1990 & $\$ 1713$ & $53 \%$ \\
1995 & $\$ 4201$ & $56 \%$ \\
2000 & $\$ 8874$ & $58 \%$ \\
2004 & $\$ 9632$ & $68 \%$ \\
\hline
\end{tabular}

Source: Compilation provided by the Bogle Financial Markets Research Center based on Federal Reserve System, Flow of Funds, Table L213 (on file with author). Figures are in nominal dollars.

Figure 6. Growth of Institutional Ownership of U.S. Public Equities

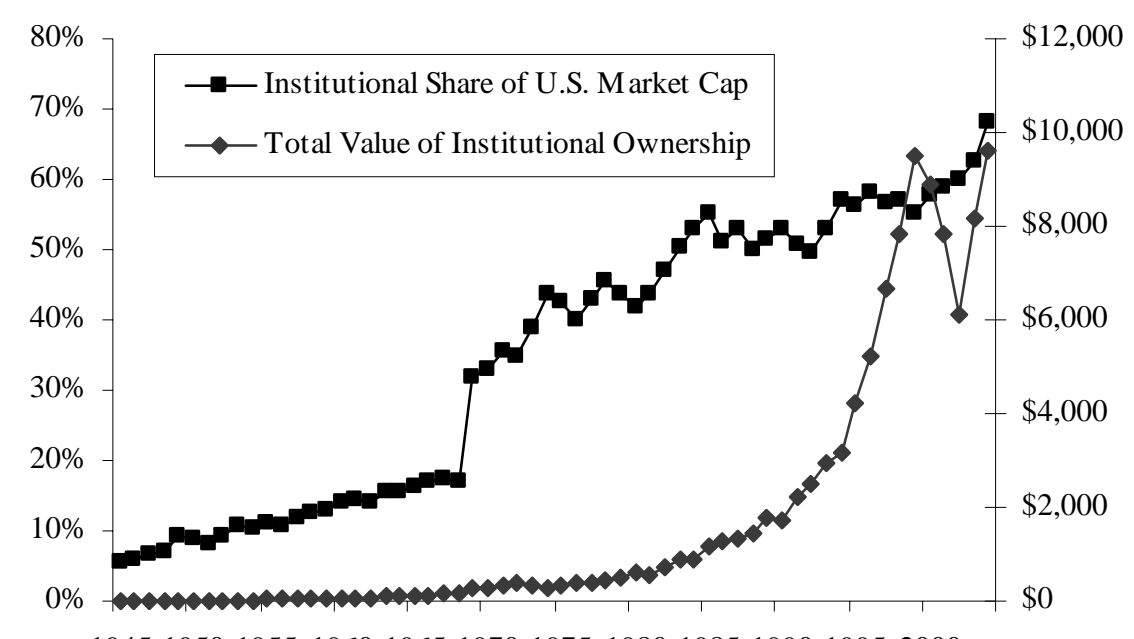

194519501955196019651970197519801985199019952000

Source: Compilation provided by the Bogle Financial Markets Research Center based on Federal Reserve System, Flow of Funds, Table L213 (on file with author). This graph vividly illustrates the increasing growth of institutional ownership, both in absolute amount (billions of dollars on the right axis) and as a percentage of publicly traded stock of U.S. firms (on the left axis). See supra note 255. 